EDUARDO KENJI HAMASATO

A influência da convivência com um parceiro doente sobre a resposta inflamatória alérgica pulmonar em camundongos

São Paulo 
EDUARDO KENJI HAMASATO

\section{A influência da convivência com um parceiro doente sobre a resposta inflamatória alérgica pulmonar em camundongos}

Tese apresentada ao Programa de Pós-Graduação em Patologia Experimental e Comparada da Faculdade de Medicina Veterinária e Zootecnia da Universidade de São Paulo para obtenção do título de Doutor em Ciências

\section{Departamento:}

Patologia

\section{Área de Concentração:}

Patologia Experimental e Comparada

\section{Orientador:}

Prof. Dr. João Palermo-Neto

São Paulo 
DADOS INTERNACIONAIS DE CATALOGAÇÃO NA PUBLICAÇÃO

(Biblioteca Virginie Buff D’Ápice da Faculdade de Medicina Veterinária e Zootecnia da Universidade de São Paulo)

T.3279

FMVZ
Hamasato, Eduardo Kenji

A influência da convivência com um parceiro doente sobre a resposta inflamatória alérgica pulmonar em camundongos / Eduardo Kenji Hamasato. -- 2016.

$112 \mathrm{f}$. il.

Tese (Doutorado) - Universidade de São Paulo. Faculdade de Medicina Veterinária e Zootecnia. Departamento de Patologia, São Paulo, 2016.

Programa de Pós-Graduação: Patologia Experimental e Comparada.

Área de concentração: Patologia Experimental e Comparada.

Orientador: Prof. Dr. João Palermo-Neto.

1. Neuroimunomodulação. 2. Tumor ascítico de Ehrlich. 3. Inflamação alérgica pulmonar 4. Citocinas Th1/Th2. 5. Catecolaminas. I. Título. 


\section{Comissão de Ética no uso de animais}

\section{CERTIFICADO}

Certificamos que o Projeto intitulado "A influência da convivência com um parceiro doente sobre a resposta inflamatória alérgica pulmonar", protocolado sob o $n^{\circ}$ 2595/2012, utilizando 240 (duzentos e quarenta) camundongos, sob a responsabilidade do Prof. Dr. João Palermo Neto, está de acordo com os princípios éticos de experimentação animal da "Comissão de Ética no uso de animais" da Fáculdade de Medicina Veterinária e Zootecnia da Universidade dé São Paulo e foi aprovado em reunião de 14/3/2012.

We certify that the Research "The influence of cohabitation with a sick cage mate on pulmonary allergic inflammatory response", protocol number 2595/2012, utilizing 240 (two hundred forty) mice, under the responsibility Prof. Dr. João Palermo Neto, agree with Ethical Principles in Animal Research adopted by "Ethic Committee in the use of animals" of the School of Veterinary Medicine and Animal Science of University of São Paulo and was approved in the meeting of day $3 / 14 / 2012$.

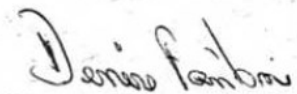

Denise Tabacchi Fantoni

Presidente 
FOLHA DE AVALIAÇÃO

Autor: HAMASATO, Eduardo Kenji

Título: A influência da convivência com um parceiro doente sobre a resposta inflamatória alérgica pulmonar em camundongos.

Tese apresentada ao Programa de Pós-Graduação em Patologia Experimental e Comparada da Faculdade de Medicina Veterinária e Zootecnia da Universidade de São Paulo para obtenção do título de Doutor em Ciências

Data:

\section{Banca Examinadora}

Prof.Dr.

Instituição:

Julgamento:

Prof.Dr.

Instituição: Julgamento:

Prof.Dr.

Instituição:

Julgamento:

Prof.Dr.

Instituição: Julgamento:

Prof.Dr.

Instituição: Julgamento: 
Esta tese foi realizada no Laboratório de Neuroimunomodulação do Departamento de Patologia da Faculdade de Medicina Veterinária e Zootecnia da Universidade de São Paulo,

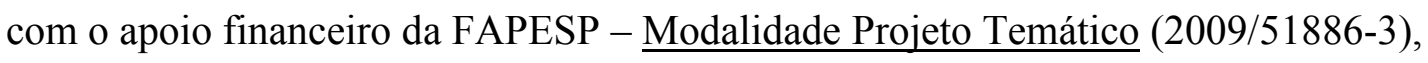
Modalidade Bolsa de Doutorado (2012/03372-3) e Modalidade Bolsa BEPE (2013/25146-8). 


\section{DEDICATÓRIA}

Dedico este trabalho à minha família

Aos meus pais Takashi e Luiza Por terem colocado a minha educação como prioridade Por terem me apoiado em todos os momentos Pelo amor, carinho e incentivo A minha irmã Gabriela Pelo apoio constante e pela amizade 
Ao Professor Dr. João Palermo-Neto, por me receber em seu grupo de pesquisa, pela orientação neste trabalho e por seus ensinamentos.

Um exemplo de profissionalismo, comprometimento e dedicação ao ensino e à ciência.

Muito Obrigado Dr. João! 
"A alegria que se tem em pensar e aprender faz-nos pensar e aprender ainda mais".

Aristóteles 


\section{AGRADECIMENTOS}

À Faculdade de Medicina Veterinária e Zootecnia (FMVZ) da Universidade de São Paulo (USP).

Ao Departamento de Patologia e Toxicologia (VPT) da FMVZ-USP, local onde este trabalho foi realizado.

Ao Programa de Patologia Experimental e Comparada, programa pelo qual este trabalho foi desenvolvido.

Aos professores do Departamento de Patologia (FMVZ-USP).

Ao Prof. Dr. Terrence Deak e sua equipe (Stress Research Laboratory, Psychology Department, Binghamton University, NY) por me aceitar em seu laboratório para a realização do estágio doutorado sanduíche e proporcionar uma grande experiência nos EUA.

Ao Prof. Dr. Wothan Tavares de Lima (ICB-USP) por disponibilizar o seu laboratório para os experimentos de reatividade das vias aéreas.

Ao Prof. Dr. Amílcar Sabino Damazo (UFMT) pela ajuda no experimento de histologia pulmonar.

A Profa. Dra. Cristina de Oliveira Massoco, Profa. Dra. Ana Paula Ligeira de Oliveira e Profa. Dra Adrina Lino dos Santos Franco pelo apoio em todos os momentos da realização desta tese.

Aos pesquisadores e pós-graduandos: Ana Paula de Lima Nascimento, Daniel Cohn, Glaucie Alves Rafael Oliveira e Wanderley Quinteiro Filho pela ajuda nos experimentos, conselhos e discussões do presente trabalho.

Aos funcionários e ex-funcionários do Biotério (VPT-FMVZ): Cláudia, Idalina, Luciana, Rosiris, Nelsinho e Mauro pela dedicação e atenção diária aos alunos e aos animais.

Aos funcionários do Laboratório de Farmacologia e Toxicologia (VPT-FMVZ): Nicolle, Herculano e Wagner pela ajuda e atenção presente nos experimentos.

As secretárias e ex-secretárias do Departamento de Patologia: Adriana, Cristina e Milena.

Aos secretários da pós-graduação FMVZ: Henrique e Daura.

Aos funcionários da biblioteca da FMVZ-USP, em especial para Elza e Elena.

Ao Rodrigo Vieira (ex-secretário do Dr. João) pela amizade e por toda a ajuda prestada.

A todos os colegas da pós-graduação que contribuíram de alguma forma para a conclusão deste trabalho.

A todo o Grupo de Neuroimunomodulação pelo apoio, amizade e crescimento pessoal e profissional proporcionado.

A todos que contribuíram de alguma forma na realização deste trabalho.

Muito Obrigado! 


\section{RESUMO}

HAMASATO, E. K. A influência da convivência com um parceiro doente sobre a resposta inflamatória alérgica pulmonar em camundongos. [The influence of cohabitation with sick partner on pulmonary allergic inflammatory response in mice]. 2016. $112 \mathrm{f}$. Tese (Doutorado em Ciências) - Faculdade de Medicina Veterinária e Zootecnia, Universidade de São Paulo, São Paulo, 2016.

As relações bidirecionais entre o Sistema Nervoso e o Sistema Imune são relevantes para a manutenção da homeostase do organismo. Estudos realizados em nosso laboratório mostraram que 14 dias de coabitação com um conspecífico doente (injetado com células do tumor de Ehrlich-TAE) produziu mudanças comportamentais, endócrinas e imunológicas. Este estudo analisa os efeitos da convivência com um animal portador de tumor de Ehrlich em camundongos OVA sensibilizados e desafiados sobre a resposta alérgica pulmonar. Pares de camundongos machos foram separados em três grupos: naïve, controle e experimental. Os animais do grupo nä̈ve não foram manipulados sendo utilizados para a avaliação de parâmetros basais. Um animal de cada par dos grupos experimental e controle foi imunizado com OVA. No dia $\mathrm{D}_{(0)}$, os animais imunizados receberam uma dose reforço de OVA. No dia $\mathrm{D}_{(0)}$ os camundongos do grupo experimental que não foram manipulados foram inoculados com $5 \times 10^{6}$ células de tumor de Ehrlich; seus companheiros de gaiola moradia foram designados CAD (“companheiro do animal doente"). Os camundongos não perturbados de cada par do grupo controle foram tratados (i.p.) em $\mathrm{D}_{(0)}$ com $0,9 \%$ de $\mathrm{NaCl}$, sendo designados CAS (“companheiro do animal saudável”). O desafio intranasal com OVA foi realizado nos camundongos CAS e CAD nos dias $\mathrm{D}_{(12)}$ e $\mathrm{D}_{(13)}$; colheram-se o sangue e os tecidos no dia $\mathrm{D}_{(14)}$. Em comparação com o grupo CAS, os camundongos do grupo CAD apresentaram 14 dias após a coabitação: (1) aumento do número de eosinófilos e neutrófilos no LBA, (2) diminuição na contagem de células da medula óssea, (3) aumento do níveis de IL-4 e IL-5 e diminuição de IL-10 e INF- $\gamma$ no sobrenadante do LBA, (4) aumento dos níveis de IgG1-OVA, diminuição dos níveis de IgG2a-OVA e nenhuma alteração na IgE-OVA no sangue periférico, (5) aumento na expressão de ICAM-1, VCAM-1 e L-selectina em granulócitos do LBA, (6) diminuição da reatividade da traquéia à metacolina in vitro, (7) aumento da desgranulação de mastócitos, (8) nenhuma alteração nos níveis plasmáticos de corticosterona, (9) aumento dos níveis de adrenalina e noradrenalina plasmáticas, (10) diminuição no tempo de permanência e entradas nos braços abertos do labirinto em cruz elevado, (11) diminuição da expressão de IL6 no PVN e (12) diminuição da expressão de C-fos no PFC. Estes resultados mostram que a 
convivência forçada com um animal portador de um tumor ascitico de Ehrlich exacerba a inflamação alérgica pulmonar de camundongos. Eles foram discutidos como decorrentes da estimulação do Sistema Nervoso Autônomo Simpático (SNS) pelo estresse psicológico gerado pela coabitação com o parceiro doente, via liberação de adrenalina e noradrenalina e consequente mudança no perfil de citocinas $\mathrm{Th}_{1} / \mathrm{Th}_{2}$ para uma resposta do tipo $\mathrm{Th}_{2}$. Esta alteração seria, provavelmente, um dos mecanismos responsáveis pelo aumento do recrutamento celular para as vias aéreas dos camundongos do grupo CAD.

Palavras-chave: Neuroimunomodulação. Tumor ascítico de Ehrlich. Inflamação alérgica pulmonar. Citocinas $\mathrm{Th}_{1} / \mathrm{Th}_{2}$. Catecolaminas. 


\begin{abstract}
HAMASATO, E. K. The influence of cohabitation with sick partner on pulmonary allergic inflammatory response in mice. [A influência da convivência com um parceiro doente sobre a resposta inflamatória alérgica pulmonar em camundongos]. 2016. $112 \mathrm{f}$. Tese (Doutorado em Ciências) - Faculdade de Medicina Veterinária e Zootecnia, Universidade de São Paulo, São Paulo, 2016.
\end{abstract}

The bidirectional relationship between the nervous system and the imune system is relevant for homeostatic organism maintenance. Studies from our laboratory showed that 14 days of cohabitation with a sick conspecific (injected with Ehrlich tumor cells-TAE) produced behavioral, endocrinological and immunological changes. This study analyzes the effects of cohabitation with an Ehrlich tumor-bearing animal on ovalbumin (OVA)-induced lung inflammatory response in mice. Pairs of male mice were separate into three groups: naïve, control and experimental. Animals of the naïve group were kept undisturbed being used for assessment of basal parameters. One animal of each experimental and control pair of mice was immunized with OVA. On $\mathrm{D}_{(0)}$, these OVA-immunized animals received an OVA booster. At this day $\left(\mathrm{D}_{(0)}\right)$ the experimental mice that were kept undisturbed were inoculated with $5 \times 10^{6}$ Ehrlich tumor cells; their immunized cage-mates were then referred as to CSP(“companion of sick partner"). The undisturbed mice of each control pair were i.p. treated on $\mathrm{D}_{(0)}$ with $0.9 \% \mathrm{NaCl}$; their sensitized cage-mate were subsequently referred as $\mathrm{CHP}$ ("companion of health partner"). The intranasal OVA challenge was performed on CSP and CHP mice on $\mathrm{D}_{(12)}$ and $\mathrm{D}_{(13)}$; blood and tissue collection were performed on $\mathrm{D}_{(14)}$. Fourteen days after cohabitation, in comparison to the CHP mice, the CSP mice displayed the following: (1) an increased number of eosinophils and neutrophils in the BAL, (2) a decreased bone marrow cell count, (3) increased levels of IL-4 and IL-5 and decreased levels of IL-10 and INF- $\gamma$ in the BAL supernatant, (4) increased levels of IgG1-OVA, decreased levels of IgG2a-OVA and no changes in OVA-specific IgE in the peripheral blood, (5) increased expression of ICAM-1, VCAM-1 and L-selectin in the BAL granulocytes, (6) decreased tracheal reactivity to metacholine measured in vitro, (7) increased mast cell degranulation, (8) no changes in plasma corticosterone levels (9) increased levels of plasmatic adrenaline and noradrenaline, (10) decreased time and \% of entries on open arms of elevated plus maze, (11) decreased expression of IL-6 on PVN and (12) decreased expression of C-fos on PFC. These results suggest that cohabitation with an Ehrlich tumor bearing mice exacerbates allergic lung inflammatory response in mice. Most probably, the changes observed in CSP mice are a 
consequence of the psychological stress induced by forced cohabitation with the sick partner. Strong involvement of the sympathetic nervous system through adrenaline and noradrenaline release and a shift of the $\mathrm{Th}_{1} / \mathrm{Th}_{2}$ cytokine profile toward a $\mathrm{Th}_{2}$ response were considered to be the mechanisms underlying the cell recruitment to the animal's airways.

Keywords: Neuroimmunomodulation. Ehrlich ascites tumor. Allergic lung inflammation. $\mathrm{Th}_{1} / \mathrm{Th}_{2}$ cytokines. Catecholamines. 


\section{LISTA DE FIGURAS}

Figura 1 - Formação dos grupos experimental, controle e naïve 38

Figura 2 - Protocolo de indução da inflamação alérgica pulmonar em camundongos 39

Figura 3 - Efeitos da convivência por 14 dias com um conspecífico portador do TAE sobre o número de células totais do LBA (A), sangue periférico (B) e medula óssea $(\mathrm{C})$ de camundongos OVA sensibilizados e desafiados

Figura 4 - Efeitos da convivência por 14 dias com um conspecífico portador do TAE sobre a produção de IL-4 (A), IL-5 (B), IL-10 (C) e INF- $\gamma$ (D) no sobrenadante do LBA de camundongos OVA sensibilizados e desafiados

Figura 5 - Efeitos da convivência por 14 dias com um conspecífico portador do TAE sobre os níveis de IgG1-OVA (A), IgG2a-OVA (B) e IgE-OVA (C) no soro de camundongos OVA sensibilizados e desafiados

Figura 6 - Efeitos da convivência por 14 dias com um conspecífico portador do TAE sobre a expressão das moléculas de adesão celular ICAM-1 (A), VCAM-1 (B) e L-selectina (C) em granulócitos do LBA de camundongos OVA sensibilizados e desafiados

Figura 7 - Efeitos da convivência por 14 dias com um conspecífico portador do TAE sobre a reatividade in vitro da traquéia à metacolina de camundongos OVA sensibilizados e desafiados

Figura 8 - Efeitos da convivência por 14 dias com um conspecífico portador do TAE sobre a desgranulação de mastócitos pulmonares de camundongos OVA sensibilizados e desafiados

Figura 9 - Efeitos da convivência por 3, 6, 9, 12 e 14 dias com um conspecífico portador do TAE sobre os níveis plasmáticos de corticosterona de camundongos OVA sensibilizados e desafiados

Figura 10 - Efeitos da convivência por 14 dias com um conspecífico portador do TAE sobre a distância percorrida (A), velocidade média (B), porcentagem de tempo na zona central $(\mathrm{C})$, porcentagem de tempo na zona intermediária (D) e porcentagem de tempo na zona tigmotáxica (E) de camundongos sensibilizados e desafiados com OVA avaliados no campo aberto 
Figura 11 - Efeitos da convivência por 14 dias com um conspecífico portador do TAE sobre a (A) distância percorrida, (B) velocidade média, (C) porcentagem de entradas e o (D) tempo de permanência nos braços abertos, (E) porcentagem de entradas e o (F) tempo de permanência nos braços fechados de camundongos OVA sensibilizados e desafiados avaliados no labirinto em cruz elevado

Figura 12 - Efeitos da convivência por 14 dias com um conspecífico portador do TAE sobre a expressão de B-actin (A), C-fos (B), IL-1 $\beta$ (C), IL-6 (D), IL-4 (E), IL-5 (F), IL-13 (G), IL-33 (H) no núcleo paraventricular do hipotálamo de camundongos OVA sensibilizados e desafiados

Figura 13 - Efeitos da convivência por 14 dias com um conspecífico portador do TAE sobre a expressão de B-actin (A), C-fos (B), IL-1 $\beta$ (C), IL-6 (D), IL-4 (E), IL-5 (F), IL-13 (G), IL-33 (H) no núcleo central da amígdala de camundongos OVA sensibilizados e desafiados

Figura 14 - Efeitos da convivência por 14 dias com um conspecífico portador do TAE sobre a expressão de B-actin (A), C-fos (B), IL-1 $\beta$ (C), IL-6 (D), IL-4 (E), IL-5 (F), IL-13 (G), IL-33 (H) no córtex pré-frontal de camundongos OVA sensibilizados e desafiados 


\section{LISTA DE TABELAS}

Tabela 1 - Efeitos da convivência por 14 dias com um conspecífico portador do TAE sobre a contagem diferencial de leucócitos do LBA de camundongos OVA sensibilizados e desafiados

Tabela 2 - Efeitos da convivência por 14 dias com um conspecífico portador do TAE sobre a presença de mastócitos intactos, desgranulados, porcentagem relativa e total número de mastócitos pulmonares de camundongos OVA sensibilizados e desafiados

Tabela 3 - Efeitos da convivência por 14 dias com um conspecífico portador do TAE sobre o peso relativo de baço, glândulas adrenais e timo de camundongos OVA sensibilizados e desafiados.

Tabela 4 - Efeitos da convivência por 9 e 14 dias com um conspecífico portador do TAE sobre os níveis plasmáticos de adrenalina e noradrenalina de camundongos OVA sensibilizados e desafiados 


\section{LISTA DE ABREVIATURAS}

ACTH: hormônio adrenocorticotrófico

ADR: adrenalina

CAD: companheiro do animal doente

CAS: companheiro do animal saudável

CeA: núcleo central da amígdala

$\mathrm{D}_{(14)}$ : dia experimental 14

Elisa: Enzyme-linked immunosorbent assay

HPA: hipotálamo pituitária adrenal

IL: interleucina

IN: instilação intranasal

INF- $\gamma$ : interferon gama

IP: intraperitoneal

LBA: lavado broncoalveolar

LPS: lipopolissacarídeo

NK: células natural killer

NOR: noradrenalina

OVA: ovalbumina

PBS: salina tamponada com fosfato

PFC: cortex pré-frontal

PMA: miristato acetato de forbol

PVN: núcleo paraventricular do hipotálamo

SC: subcutânea

SI: sistema imune

SNS: sistema nervoso autônomo simpático

SNC: sistema nervoso central

TAE: tumor ascítico de Ehrlich

$\mathrm{TH}_{1}$ : linfócito $\mathrm{T}$ helper 1

$\mathrm{TH}_{2}$ : linfócito $\mathrm{T}$ helper 2

TLR4: receptores do tipo toll 4

TNF: fator de necrose tumoral

TSH: hormônio tireotrófico 


\section{SUMÁRIO}

1 INTRODUÇÃO .................................................................................................................... 21

2 REVISÃO DE LITERATURA...................................................................................... 23

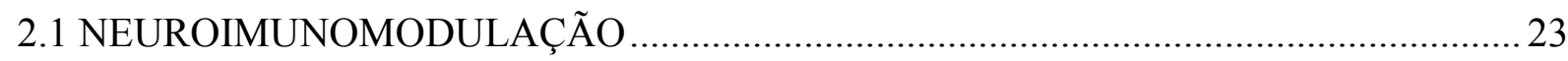

2.2 O TUMOR ASCÍTICO DE EHRLICH E A CONVIVÊNCIA COM CONSPECÍFICO

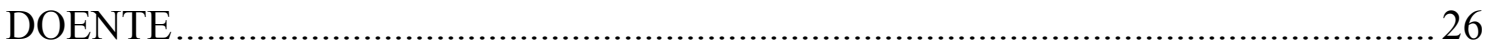

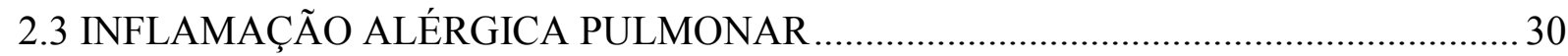

3 OBJETIVOS ............................................................................................................................ 34

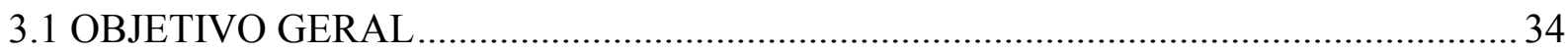

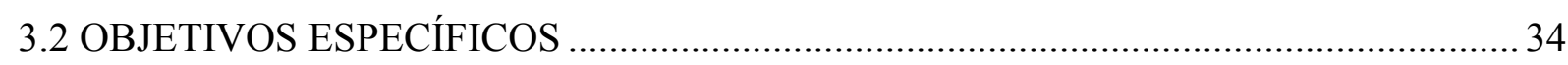

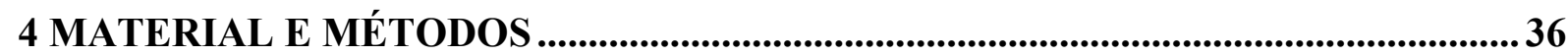

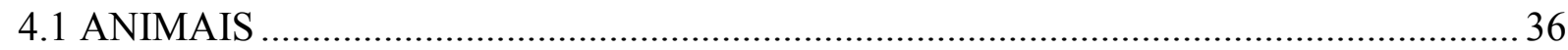

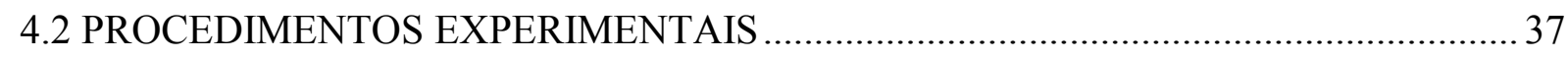

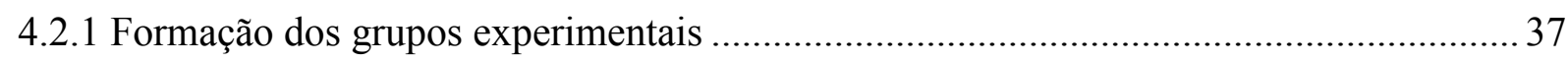

4.2.2 Modelo de inflamação alérgica pulmonar em camundongos ............................................. 39

4.2.3 Obtenção e manutenção de células do tumor ascítico de Ehrlich........................................ 39

4.2.4 Contagem total e diferencial de leucócitos do lavado broncoalveolar (LBA) ................. 40

4.2.5 Contagem de leucócitos do sangue periférico ……………………………………….... 40

4.2.6 Contagem da celularidade da medula óssea ............................................................... 41

4.2.7 Quantificação de citocinas no sobrenadante do LBA e imunoglobulinas no soro ........... 41

4.2.8 Quantificação da expressão das moléculas de adesão celular ICAM-1, VCAM-1 e

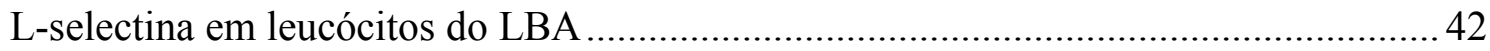

4.2.9 Avaliação da reatividade das vias aéreas in vitro através de traquéia isolada.................. 42

4.2.10 Fixação, processamento e inclusão do tecido pulmonar para avaliação da desgranulação de mastócitos ............................................................................................ 43

4.2.11 Peso relativo de tecidos periféricos (baço, adrenais e timo)............................................ 43

4.2.12 Dosagem dos níveis plasmáticos de corticosterona....................................................... 43

4.2.13 Dosagem dos níveis plasmáticos de catecolaminas....................................................... 44

4.2.14 Medida da atividade locomotora no campo aberto....................................................... 44

4.2.15 Medida de ansiedade por meio do labirinto em cruz elevado ........................................ 45

4.2.16 Análise da expressão gênica de citocinas no SNC ………………………………….... 46

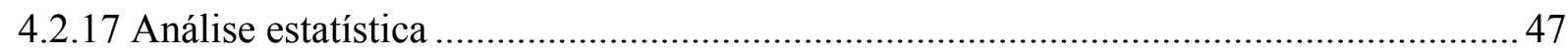


5 DELINEAMENTO EXPERIMENTAL E RESULTADOS

5.1 EXPERIMENTO 1 - AVALIAÇÃO DOS EFEITOS INDUZIDOS PELA CONVIVÊNCIA POR 14 DIAS COM UM CONSPECÍFICO PORTADOR DO TAE SOBRE A MIGRAÇÃO CELULAR NO LBA, SANGUE PERIFÉRICO E MEDULA ÓSSEA.

5.2 EXPERIMENTO 2 - AVALIAÇÃO DOS EFEITOS INDUZIDOS PELA CONVIVÊNCIA POR 14 DIAS COM UM CONSPECÍFICO PORTADOR DO TAE SOBRE OS NÍVEIS DAS CITOCINAS IL-4, IL-5, IL-10 E IFN- $\gamma$ NO SOBRENADANTE DO LBA

5.3 EXPERIMENTO 3 - AVALIAÇÃO DOS EFEITOS INDUZIDOS PELA CONVIVÊNCIA POR 14 DIAS COM UM CONSPECÍFICO PORTADOR DO TAE SOBRE OS NÍVEIS DAS IMUNOGLOBULINAS IGE-OVA, IGG1-OVA E IGG2A-OVA NO SORO

5.4 EXPERIMENTO 4 - AVALIAÇÃO DOS EFEITOS INDUZIDOS PELA CONVIVÊNCIA POR 14 DIAS COM UM CONSPECÍFICO PORTADOR DO TAE SOBRE A EXPRESSÃO DAS MOLÉCULAS DE ADESÃO CELULAR ICAM-1, VCAM-1 E L-SELECTINA EM GRANULÓCITOS DO LBA

5.5 EXPERIMENTO 5 - AVALIAÇÃO DOS EFEITOS INDUZIDOS PELA CONVIVENCIA POR 14 DIAS COM UM CONSPECÍFICO PORTADOR DO TAE SOBRE A REATIVIDADE IN VITRO DA TRAQUÉIA À METACOLINA ...... 54

5.6 EXPERIMENTO 6 - AVALIAÇÃO DOS EFEITOS INDUZIDOS PELA CONVIVENNCIA POR 14 DIAS COM UM CONSPECÍFICO PORTADOR DO TAE SOBRE A DESGRANULAÇÃO DE MASTÓCITOS

5.7 EXPERIMENTO 7 - AVALIAÇÃO DOS EFEITOS INDUZIDOS PELA CONVIVÊNCIA POR 14 DIAS COM UM CONSPECÍFICO DOENTE SOBRE O PESO RELATIVO DE ÓRGÃOS PERIFÉRICOS (BAÇO, GLÂNDULAS ADRENAIS E TIMO)

5.8 EXPERIMENTO 8 - AVALIAÇÃO DOS EFEITOS INDUZIDOS PELA CONVIVÊNCIA POR 3, 6, 9, 12 E 14 DIAS COM UM CONSPECÍFICO PORTADOR DO TAE SOBRE OS NÍVEIS PLASMÁTICOS DE CORTICOSTERONA....

5.9 EXPERIMENTO 9 - AVALIAÇÃO DOS EFEITOS INDUZIDOS PELA CONVIVÊNCIA POR 9 E 14 DIAS COM UM CONSPECÍFICO PORTADOR DO TAE SOBRE OS NÍVEIS PLASMÁTICOS DE ADRENALINA E NORADRENALINA

5.10 EXPERIMENTO 10 - AVALIAÇÃO DOS EFEITOS INDUZIDOS PELA CONVIVÊNCIA POR 14 DIAS COM UM CONSPECÍFICO PORTADOR DO TAE SOBRE A ATIVIDADE GERAL NO CAMPO ABERTO. 
5.11 EXPERIMENTO 11 - AVALIAÇÃO DOS EFEITOS INDUZIDOS PELA CONVIVÊNCIA POR 14 DIAS COM UM CONSPECÍFICO PORTADOR DO TAE SOBRE OS NÍVEIS DE ANSIEDADE AVALIADOS NO LABIRINTO EM CRUZ ELEVADO (LCE)

5.12 EXPERIMENTO 12 - AVALIAÇÃO DOS EFEITOS INDUZIDOS PELA CONVIVÊNCIA POR 14 DIAS COM UM CONSPECÍFICO PORTADOR DO TAE SOBRE A EXPRESSÃO DE CITOCINAS NO NÚCLEO PARAVENTRICULAR DO HIPOTÁLAMO, CENTRAL DA AMÍGDALA E

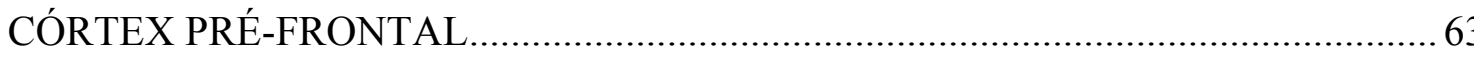

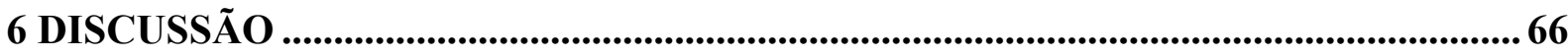

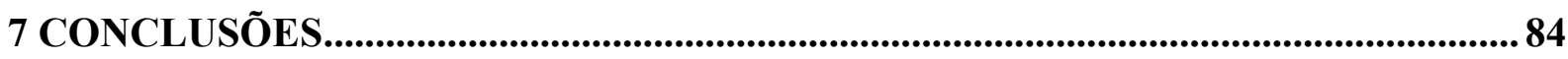

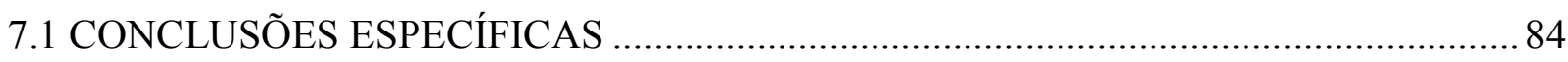

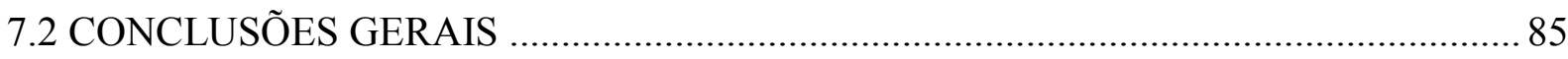

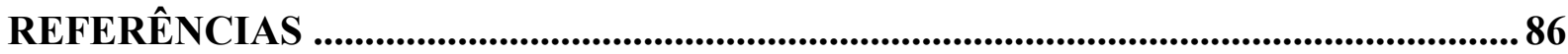

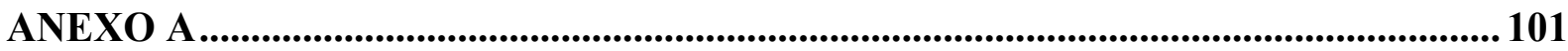

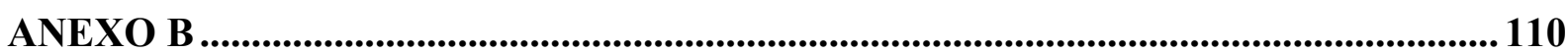




\section{INTRODUÇÃO}

"Pensei que não fosse acontecer nada" surpreso, relatou o renomado pesquisador João Palermo-Neto ao repórter da Revista FAPESP, edição 96, de fevereiro de 2004 ao se referir ao resultado de um experimento inusitado em seu laboratório no qual camundongos sadios conviveram com animais portadores de tumor. "Após terem sido colocados juntos, depois de alguns dias os camundongos sadios passaram a se comportar como os companheiros doentes". Mas especificamente, o Dr. João Palermo-Neto se referia a coabitação por 11 dias de camundongas Swiss com uma conspecífica portadora do tumor ascítico de Ehrlich.

Os resultados intrigantes dos estudos conduzidos dentro desta linha de pesquisa mostraram que a coabitação induziu: (a) uma maior susceptibilidade ao desenvolvimento do mesmo tumor experimental, ao fim do período de convívio com o conspecífico doente (MORGULIS et al., 2004); (b) um aumento de atividade motora no campo aberto (ALVES et al., 2006); (c) uma diminuição nos níveis e um aumento do turnover hipotalâmico de NOR; (d) uma diminuição no burst oxidativo de neutrófilos após a indução com miristato acetato de forbol (PMA) ou com Staphylococcus aureus; (e) uma diminuição na porcentagem e na intensidade de fagocitose de neutrófilos (ALVES et al., 2006) (f) diminuição do tempo de permanência junto à companheira doente em um labirinto em $\mathrm{T}$; $(\mathrm{g})$ aumento da interação social; (h) a convivência não modificou os níveis de corticosterona dos animais desafiados ou não por contenção (ALVES; RIBEIRO; PALERMO-NETO, 2012); (i) os níveis de adrenalina e noradrenalina plasmáticas estavam aumentados 2, 4 e 9 dias após a convivência com um animal doente, contudo uma diminuição de catecolaminas foi observada no dia 14 de convivência com o conspecífico doente (ALVES; PALERMO-NETO, 2015); estímulos olfativos provenientes do animal doente eram fundamentais para a manifestação das alterações induzidas pela convivência sobre o burst oxidativo e fagocitose de neutrófilos, crescimento tumoral, alterações comportamentais, níveis plasmáticos de adrenalina e noradrenalina elevados, assim como redução dos níveis e aumento do turnover de noradrenalina no hipotálamo (ALVES; RIBEIRO; PALERMO-NETO, 2012). Estes resultados, levaram os autores a sugerir que as alterações que observaram poderiam ser decorrentes de uma ativação das vias noradrenérgicas no Sistema Nervoso Central (SNC) e no Sistema Nervoso Autônomo Simpático (SNS). Analisando-se estes resultados em seu 
conjunto depreende-se que a convivência com um animal portador de um tumor ascítico de Ehrlich produz relevantes alterações em parâmetros comportamentais, neuroendócrinos e imunes; estas alterações foram interpretadas como sendo desencadeadas pela estimulação olfativa proveniente do animal doente; de fato, a remoção mecânica da percepção dos odores liberados pelos animais doentes reverteu as alterações neuroimunes observadas (ALVES; PALERMO-NETO, 2015). Estes fatos nos levam a sugerir que animais, em especial, os roedores, têm sua fisiologia e homeostase modificadas de forma marcante pela convivência com um companheiro doente.

Deste os estudos iniciais, 12 anos se passaram, 9 trabalhos foram publicados e 4 dissertações e teses defendidas sobre o tema "convivência com um conspecífico doente" sob a orientação do Dr. João Palermo Neto. O presente trabalho avaliou dentro de uma perspectiva neuroimune, os efeitos da convivência com um conspecífico portador do tumor ascítico de Ehrlich sobre parâmetros imunes, neuroendócrinos e comportamentais de camundongos OVA sensibilizados e desafiados, um modelo experimental de inflamação alérgica pulmonar. 


\section{REVISÃO DE LITERATURA}

\subsection{NEUROIMUNOMODULAÇÃO}

Neuroimunomodulação é o campo científico transdisciplinar preocupado em estudar as interações entre cérebro (mente/comportamento) e o sistema imunológico e suas consequentes implicações clínicas. Neuroimunomodulação é o termo cunhado por Robert Ader nos anos 1970 para definir esta relação, no entanto, este campo científico é também conhecido pelo termo psiconeuroimunologia e, menos comumente, neuroendocrinologia ou imunologia comportamental. Os seus aspectos clínicos variam em torno da compreensão dos mecanismos biológicos subjacentes à influência de estressores e de fatores psicossociais no início e curso de doenças mediadas imunologicamente. Desta forma, pela sua própria natureza, os conhecimentos de Neuroimunomodulação atingem disciplinas tradicionais no âmbito da psiquiatria, psicologia, neurologia, endocrinologia, imunologia, neurociências e medicina. A colaboração interdisciplinar é geralmente essencial e intrínseca à sua pesquisa.

Desde o trabalho pioneiro de Hans Selye em 1936, sabe-se que o SNC, pela mediação que exerce sobre funções neurovegetativas durante o estresse, é capaz de influenciar respostas orquestradas pelo Sistema Imune (SI). Selye em 1936 analisou as alterações ocasionadas durante o estresse, entre outras, no tamanho das adrenais, do timo, do baço e dos linfonodos. Embasado em alterações como estas, este autor descreveu o desenvolvimento de uma síndrome que chamou de "adaptação geral". No entanto, apenas em 1977 surgiu o primeiro trabalho que descreveu a ocorrência de uma redução na função de linfócitos após uma situação de estresse: o luto pela perda de um companheiro. Este trabalho mostrou, de forma inequívoca, que uma situação de estresse de natureza psicológica produziu alterações da função imune de maneira independente de hormônios (BARTROP et al., 1977).

Há uma variedade de categorias de evidências que mostram a existência de uma comunicação bidirecional entre o sistema nervoso central e o sistema imune tais como: experimentais e naturalísticas; de cunho básico e clínica; animal e humano; in vitro e in vivo; de clínica médica ou psiquiátrica. De fato, faz sentido que estes dois sistemas estejam conectados; de fato, ambos relacionam o organismo com o mundo exterior e avaliam seus 
componentes como inofensivo ou perigoso, ambos servem a funções de defesa e adaptação, ambos possuem memória e aprendem com a experiência, ambos contribuem para a homeostase, e erros de defesa por cada um deles pode evoluir para um estado de doença, como por exemplo, as doenças autoimunes ou as alergias. Há diversas evidências para a interação do sistema nervoso central e do sistema imune; dentre elas, vale ressaltar as seguintes: a) evidência direta do controle do cérebro sobre a imunidade e da inervação dos órgãos imunes; b) influências dos hormônios liberados quando do estresse sobre a imunidade; c) efeitos de neurotransmissores e neuropeptídios sobre a imunidade; d) efeitos do estresse sobre a imunidade de animais e humanos; e) efeitos de drogas psicoativas sobre a imunidade; f) correlação de diferenças individuais psicológicas com parâmetro de imunidade em animais e humanos; g) coexistência de anormalidades imunológicas com doenças mentais (depressão e esquizofrenia); h) influência de produtos do sistema imune sobre o sistema nervoso central, incluindo-se aqui alterações comportamentais induzidas imunologicamente; i) alteração por intervenção psicológica e exercício excessivo sobre a imunidade e o curso das doenças imunologicamente mediadas.

Segundo Blalock (1984) existe uma razão bioquímica lógica que justificaria as interações entre os sistemas neuroendócrino e imune. De fato, eles compartilham de receptores para citocinas, neurotransmissores, hormônios e neuropeptídios. Mais que isso, produtos originalmente tidos como específicos de cada um desses sistemas coexistem em tecidos linfóide, endócrino e nervoso, ou seja, mostrou-se que há citocinas sendo produzidas no SNC e, também hormônios como, por exemplo, ACTH (hormônio adrenocorticotrófico) e TSH (hormônio tireotrófico), sendo sintetizados em células linfóides (BESEDOVSKY; DEL REY, 1996). É a partir dessas observações que se começa a delinear o conceito da existência de uma extensa comunicação e relacionamento entre os sistemas neuroendócrino e imune e de que estas relações ocorrem nos dois sentidos, isto é, tanto mecanismos neuroendócrinos modulam a atividade do sistema imune, quanto este influencia a atividade do sistema neuroendócrino (MADDEN; SANDERS; FELTEN, 1995). Blalock em 1984 referia-se ao sistema imunológico como o "sexto sentido", uma vez que ele encaminha ao cérebro informações de aspectos moleculares e celulares do ambiente não accessíveis pelos cinco sentidos, mais recentemente, o nominou de um "espelho da mente".

Nesse sentido, diversos trabalhos desenvolvidos em nossos laboratórios têm contribuído para o fortalecimento dessas ideias. Como exemplo, Basso, De Sa-Rocha e Palermo-Neto (2001) demonstraram que camundongos imunizados com OVA desenvolvem 
uma aversão ao antígeno presente na dieta. Deste modo, frente à opção de ingerir água ou uma solução adocicada de clara de ovo, os animais não imunizados preferem beber a solução doce, enquanto animais imunizados com OVA passam a evitar a solução doce que contém o antígeno, ingerindo preferencialmente água (BASSO; DE SA-ROCHA; PALERMO-NETO, 2001). Além disso, os animais imunizados com OVA e desafiados com o antígeno por via oral apresentam níveis elevados de ansiedade e maior expressão de C-fos em áreas do SNC como o núcleo paraventricular do hipotálamo (PVN) e o núcleo central da amígdala (CeA), regiões estas relacionadas à emotividade (BASSO et al., 2003).

Outro trabalho de nosso laboratório que fortalece a importância da integração entre os sistemas imune e nervoso na adaptação dos animais a estímulos do meio ambiente foi desenvolvido por Costa-Pinto et al. (2005). Assim, camundongos imunizados com OVA evitaram a exploração de um ambiente previamente associado à exposição ao antígeno por nebulização (COSTA-PINTO et al., 2005). Neste caso, a reação alérgica nas vias aéreas levou a uma resposta comportamental em que os animais passaram a evitar o lado escuro de uma caixa, supostamente mais seguro, para ficar no compartimento claro, porém, considerado desconfortável para os animais. De igual forma, esse desafio nasal levou à ativação do PVN e do CeA de animais imunizados com OVA (COSTA-PINTO et al., 2005). Já havia sido demonstrado que ratos que foram expostos a um estímulo visual previamente associado com uma resposta alérgica pulmonar apresentavam alterações comportamentais, ou seja, exploravam por menos tempo os braços abertos do labirinto em cruz elevado, indicando que a reação alérgica nas vias aéreas é capaz de elevar os níveis de ansiedade de animais imunizados com OVA, efeito este que pode ser condicionado (PALERMO-NETO; GUIMARÃES, 2000).

Para sobreviver, os organismos devem manter em equilíbrio a dinâmica e complexa homeostase. Uma vez perturbada por estressores endógenos ou exógenos, são ativados o sistema nervoso autônomo simpático (SNS) e o eixo hipotálamo pituitária adrenal (HPA). Em condições fisiológicas, os glicocorticóides e as catecolaminas atuam como reguladores do metabolismo, participam da termogênese, regulam a atividade cardíaca e tônus dos vasos sanguíneos (ELENKOV et al., 2000). O SNS é o maior componente do sistema nervoso autônomo, inervando todas as partes do corpo, incluindo-se aqui os órgãos linfóides primários e secundários (MADDEN; SANDERS; FELTEN, 1995). Dessa forma, os produtos do sistema nervoso e endócrino alteram o funcionamento do sistema imune (ADER; COHEN; FELTEN, 1995). O SNS contribui com as respostas fisiológicas ao estresse pela liberação de 
catecolaminas pelos nervos simpáticos em proximidade aos tecidos linfóides; as catecolaminas, por sua vez, exercem seus efeitos sobre as células imunes ao se ligar a receptores adrenérgicos acoplados a proteína G (KOHM; SANDERS, 2001; SANDERS et al., 2003). Além disso, adrenalina e noradrenalina são liberadas da medula da adrenal após o SNS ser ativado durante a resposta ao estresse. Em paralelo, ocorre à liberação de glicocorticóides do córtex da adrenal.

Sabe-se que a adrenalina e a noradrenalina exercem seus efeitos sobre as células imunes pela estimulação de duas principais subclasses de receptores: os receptores alfa e beta adrenérgicos. Ao ser estimulado, o sistema catecolaminérgico fornece ao corpo o estímulo necessário para lidar com a ameaça representada pelo estresse. Os hormônios e neurotransmissores induzidos pelo estresse se ligam a receptores específicos nas células imunes e, subsequentemente, influenciam a sua ativação e função (ELENKOV; CHROUSOS, 2002). Como um todo, isso indica que estímulos estressores induzem a ativação do eixo HPA e do SNS, o que resulta na liberação de glicocorticóides e catecolaminas respectivamente, compondo assim, um significante mecanismo pelo qual os sistemas nervoso, endócrino e imune se interconectam durante a resposta ao estresse, na busca de reestabelecer a homeostase do organismo. De fato, a ativação de vias autonômicas e neuroendócrinas tem um impacto profundo nas respostas fisiológicas como demonstrado tanto em seres humanos como em roedores (BLANCHARD; MCKITTRICK; BLANCHARD, 2001; KIECOLT-GLASER; GLASER, 2002; KINSEY et al., 2007)

\subsection{O TUMOR ASCÍTICO DE EHRLICH E A CONVIVÊNCIA COM CONSPECÍFICO DOENTE}

O tumor ascítico de Ehrlich (TAE) é um adrenocarcinoma mamário (MAYER, 1966; JOHNSON; JONDORF, 1974) adaptado para a forma ascítica (HARTVEIT, 1966; MAYER, 1966) e transferido para camundongos por uma série de passagens intraperitoneais. A forma ascítica do TAE tem sido utilizada em modelos experimentais para avaliar a influência de fármacos de diferentes origens em suas respostas de proliferação e do hospedeiro contra as células tumorais (AHMED; CHATTERJEE; DEBNATH, 1988; VIEIRA et al., 2010). A 
ascite característica é provavelmente formada como consequência da resposta inflamatória das células tumorais, resultando de uma permeabilidade vascular peritoneal aumentada (BALAMURUGAN; REDDY; MENON, 2010). Outros fatores que contribuem para a ascite e consequente letalidade do TAE incluem a prejudicada drenagem linfática peritoneal pelas células tumorais (NAGY et al., 1989; GUPTA et al., 2004), a pressão mecânica exercida pelo progressivo aumento de fluido ascítico, a hemorragia peritoneal, e a endotoxemia (KUMAR et al., 2009; VIEIRA et al., 2010; KITAGISHI; KOBAYASHI; MATSUDA, 2012).

Diversos são os estudos de nosso laboratório que utilizaram o TAE como modelo experimental para se estudar os efeitos de fármacos (cialotrina e diazepam); estressores físicos e psicológicos e o isolamento social. Dentre estes trabalhos podemos destacar aqueles que analisaram os efeitos induzidos pela cialotrina sobre o crescimento do TAE (QUINTEIROFILHO; RIGHI; PALERMO-NETO, 2009). Mostrou-se que a cialotrina, um piretróide inseticida, administrado em camundongos na dose de $3 \mathrm{mg} / \mathrm{Kg}$ (i.g.) por 7 dias consecutivos aumentou o crescimento tumoral, isto é, o volume de fluído ascítico, a concentração de células tumorais por volume de fluído ascítico e o número total de células tumorais no fluído ascítico. Este trabalho mostra que a cialotrina diminui a resistência orgânica de camundongos ao crescimento tumoral. Em outro grupo de estudos, Sakai et al. analisaram os efeitos do diazepam sobre as células do TAE, os autores mostraram que o diazepam, um benzodiazepínico amplamente utilizado devido as suas propriedades ansiolíticas e sedativas, aumenta o crescimento tumoral muito provavelmente por atuar sobre a atividade de macrófagos dos camundongos inoculados com o TAE. De fato, os resultados mostraram que o diazepam na dose de $3 \mathrm{mg} / \mathrm{Kg}$ administrado durante 7 dias consecutivos aumentou o número de células tumorais e o volume do fluído ascítico. Desta forma, sugere-se que o diazepam tenha aumentado o crescimento do TAE e diminuído a resposta imune inata, fato observado por meio da diminuição da atividade de macrófagos peritoneais (SAKAI et al., 2006a,b ; SAKAI et al., 2010).

Os efeitos do isolamento social sobre o comportamento e a resistência ao crescimento tumoral foi elegantemente mostrado (PALERMO-NETO et al., 2008). Neste trabalho o isolamento social por 21 dias aumentou o volume do fluído ascítico, o número de células tumorais e diminuiu o tempo de sobrevivência em relação a camundongos que conviveram em grupos de 10 a 12 animais por gaiola. Mostrou-se que a condição de isolamento social induz alterações na resposta neuroendócrina e, ao mesmo tempo, diminui a resistência ao crescimento tumoral. 
Os efeitos do estresse físico e psicológico sobre o comportamento, atividade de macrófagos e resistência ao crescimento tumoral foram também relatados (PALERMONETO; DE OLIVEIRA MASSOCO; ROBESPIERRE DE SOUZA, 2003). Neste experimento, os camundongos foram submetidos a uma série de choques nas patas do tipo escapável ou inescapável, diariamente por 6 dias consecutivos e quando desafiados com a inoculação do TAE apresentaram um aumento expressivo do crescimento tumoral. Curiosamente, observou-se neste estudo que os animais que assistiam seus conspecíficos receberem o choque também apresentaram alterações imunes e de resistência ao crescimento tumoral.

Também foram investigados em nossos laboratórios os efeitos do estresse maternal sobre os níveis de ansiedade, atividade de macrófagos e crescimento tumoral (PALERMO NETO; MASSOCO; FAVARE, 2001). Mostrou-se um aumento do crescimento tumoral nas formas ascítica e sólida do TAE na prole aos 60 dias de vida após as camundongas gestantes receberem choque nas patas entre os dias gestacionais $D_{(15)}$ ao $D_{(19)}$.

Por tudo quanto exposto, estes dados mostram ser o modelo experimental de TAE uma valiosa ferramenta experimental para o estudo de fármacos e também sobre os efeitos do estresse sobre a resistência orgânica ao desenvolvimento de tumores e de doenças.

Nesta linha de pesquisa, inserem-se os diversos trabalhos de nosso grupo relacionados à coabitação com um conspecífico injetado com células do TAE, o modelo experimental utilizado na presente Tese. Diversos trabalhos de nosso grupo de pesquisa avaliaram os efeitos intercorrentes da coabitação com um parceiro doente, partindo do princípio que animais são seres sociais que estabelecem hierarquias e apresentam comportamento social bem definido. No primeiro deles, Morgulis et al. (2004), constataram que camundongas Swiss que conviviam com animais da mesma linhagem portadores do TAE apresentavam uma menor resistência a este mesmo tumor quando desafiados após 11 dias de convívio. Ao analisarem o comportamento dos animais submetidos a esta condição, observaram aumento da atividade locomotora em um campo aberto, mas, de forma surpreendemente, não constataram alterações significativas nos níveis de corticosterona destes mesmos animais.

Alves et al. (2006), em sequência, mostraram que camundongas que coabitaram por 11 dias com conspecíficas doentes apresentavam aumento de atividade motora no campo aberto e diminuição da resistência orgânica ao crescimento de um tumor ascítico de Ehrlich. Esta 
coabitação com um animal doente induziu também (a) uma diminuição nos níveis e um aumento do turnover hipotalâmico de noradrenalina (NOR); (b) uma diminuição no burst oxidativo de neutrófilos após a indução com miristato acetato de forbol (PMA) ou com Staphylococcus aureus; (c) uma diminuição na porcentagem e na intensidade de fagocitose de neutrófilos (ALVES et al., 2006). A fagocitose de macrófagos peritoneais também foi menor nas camundongas que conviveram com conspecíficas doentes em relação ao grupo controle, ou seja, animais que haviam convivido com companheiras saudáveis (ALVES; VISMARI; PALERMO-NETO, 2007).

De relevância, observaram também em camundongas que conviveram com portadoras de um tumor por 14 dias: 1) redução do peso e da celularidade do baço; 2) redução na contagem diferencial de blastos, eritrócitos jovens e linfócitos no esplenograma; 3) redução da porcentagem de linfócitos B e T helper e na proporção CD4/CD8 no baço; 4) aumento da atividade citotóxica de células NK; 5) aumento da celularidade total da medula; 6) aumento do número absoluto de blastos e redução daquele de eritrócitos jovens e de linfócitos no mielograma, e aumento do número relativo de blastos; 7) aumento de células em fase G1 e redução daquelas em fase G2 do ciclo celular da medula; 8) aumento de células tumorais em fase G1 e redução daquelas em fase G2 do ciclo celular do tumor ascítico de Ehrlich, 9) aumento do tempo de permanência com um animal estranho e redução deste tempo de permanência junto à companheira doente em um labirinto em $\mathrm{T}, 10$ ) aumento de interação social. Observaram também: 11) uma redução do burst oxidativo basal de neutrófilos provenientes de animais que conviveram com dois doentes, e diminuição destas alterações quanto da coabitação de um doente com dois sadios. Mostraram ainda e mais uma vez que: 12) a coabitação não modificava os níveis de corticosterona dos animais desafiados ou não por contenção e, que 13) os níveis de adrenalina e noradrenalina plasmáticas estavam aumentados 2, 4 e 9 dias após a coabitação com um animal doente. Contudo, uma significante diminuição de catecolaminas foi observada após 14 dias de coabitação com o conspecífico doente.

Mostrou-se, de forma interessante que o contato físico e visual não eram relevantes para o aparecimento das alterações induzidas pela coabitação. No entanto e, de modo relevante, observaram que estímulos olfativos provenientes do doente eram fundamentais para a manifestação das alterações induzidas pela coabitação sobre o burst oxidativo e a fagocitose de neutrófilos, o crescimento tumoral, as alterações comportamentais, os níveis plasmáticos 
de noradrenalina e adrenalina e, os níveis hipotalâmicos de noradrenalina e turnover de noradrenalina (ALVES et al., 2010; ALVES; RIBEIRO; PALERMO-NETO, 2012).

É relevante comentar que esta coabitação com um conspecífico doente quando feita com outra linhagem de camundongas (C57BL/6) e com outro tipo de tumor (melanoma) inoculado ao animal doente, produziu, também, significativas alterações nos conspecíficos como, por exemplo: aumento da atividade locomotora no campo aberto, diminuição no tempo de exploração e número de entradas no braço aberto do labirinto em cruz elevado, aumento da expressão de moléculas co-estimulatórias $\mathrm{CD} 80 \mathrm{e}^{+} \mathrm{CD} 11 \mathrm{C}^{+}$em células do baço analisadas in vitro; alteração na diferenciação das células da medula na presença de CM-CSF, IL-4 e LPS, in vitro, resultando em uma menor porcentagem de células ${ }^{+} \mathrm{CD} 80^{+}$in vitro, e uma desestabilização do organismo a uma hipersensibilização por OVA e mais uma vez não foram observadas diferenças nos níveis de corticosterona plasmáticos (TOMIYOSHI et al., 2009).

Analisando-se estes resultados em seu conjunto depreende-se que a coabitação com um conspecífico portador do TAE produz alterações comportamentais, neuroquímicas, endócrinas e de atividade imune em camundongas, desencadeadas muito provavelmente pela estimulação olfativa proveniente dos doentes (ALVES; RIBEIRO; PALERMO-NETO, 2012; ALVES; PALERMO-NETO, 2015). Trabalhos recentes de Alves e Palermo-Neto (2015) mostram que as pistas de odor liberados pelos conspecífico portador do TAE são aversivos e induzem estresse psicológico. Os autores postulam que a resposta de aversão do companheiro do animal doente ativa o SNS e, consequentemente, induz as mudanças neuroimunes observadas.

\subsection{INFLAMAÇÃO ALÉRGICA PULMONAR}

Os modelos animais de doenças alérgicas das vias respiratórias têm sido amplamente utilizados para estudar a fisiopatologia associada com a exposição recorrente a alérgenos, como observado na asma humana. A asma é uma doença inflamatória crônica complexa que envolve, simultaneamente, a participação de várias células, citocinas e mediadores inflamatórios, caracterizada principalmente por hiperreatividade das vias aéreas e por 
limitação variável do fluxo aéreo, reversível espontaneamente ou após tratamento. Observa-se na asma um aumento do número de células inflamatórias nas vias aéreas, perda do epitélio brônquico e reatividade exacerbada do músculo liso, além de uma alta produção de imunoglobulina E (IgE) (BICE; SEAGRAVE; GREEN, 2000; BLANCHET; MCNAGNY, 2009).

Como a maioria dos animais, os camundongos, naturalmente não desenvolvem uma inflamação periódica das vias aéreas como observado na asma em humanos (ZOSKY; SLY, 2007). Desta forma, modelos animais de asma requerem um protocolo de sensibilização a um alérgeno e subsequente reexposição a fim de provocar uma resposta alérgica. Um protocolo comumente utilizado é o modelo que utiliza a OVA; neste, os camundongos são injetados com ovalbumina preparada com um adjuvante, sendo posteriormente submetidos a uma reexposição à OVA apresentada, desta feita, na forma de aerossol ou por via intranasal. Os adjuvantes habitualmente utilizados são os sais de alumínio e o LPS. Os sais de alumínio aumentam as respostas de anticorpos e ativam células do sistema imunológico inato que posteriormente levam a uma resposta $\mathrm{Th}_{2}$ (LAMBRECHT et al., 2009). Já o LPS ativa os receptores do tipo toll 4 (TLR4) nas células epiteliais das vias aéreas (LUCAS; MAES, 2013), iniciando a sinalização pró-inflamatória.

Fatores genéticos e ambientais, infecções virais e bacterianas, qualidade e poluição do ar influenciam a inflamação alérgica pulmonar e a asma; contudo, o estresse continua a ser um fator importante, frequentemente relatado clinicamente em associação com a exacerbação da asma (BAILEY, 2013; TRUEBA; RITZ, 2013; VLIAGOFTIS, 2014).

Mais especificamente, a asma é caracterizada por uma resposta dominante $\mathrm{Th}_{2}$ causada por: um excesso de produção de citocinas $\mathrm{Th}_{2}$ (por exemplo, IL-4, IL-5 e IL-13); um deslocamento para a produção da imunoglobulina $\operatorname{IgE}$ e pela produção de histamina. A desregulação do equilíbrio de citocinas $\mathrm{Th}_{1} / \mathrm{Th}_{2}$ é considerada peça central na patogênese da asma e de doenças atópicas. O excesso de produção de citocinas $\mathrm{Th}_{2}$ resulta no recrutamento e consequente ativação de mediadores inflamatórios, incluindo-se aqui os mastócitos, basófilos, eosinófilos resultando em obstrução das vias respiratórias e hiperresponsividade (BARNES, 2008).

Neste contexto, parece-nos relevante comentar que os glicocorticóides e as catecolaminas são conhecidos por causar uma mudança no equilíbrio $\mathrm{Th}_{1} / \mathrm{Th}_{2}$ a favor de uma 
resposta $\mathrm{Th}_{2}$, pela supressão das células apresentadoras de antígenos, pela redução da resposta $\mathrm{Th}_{1}$ e pelo aumento da produção de citocinas $\mathrm{Th}_{2}$. Estudos têm mostrado que os glicocorticóides inibem a produção das citocinas $\mathrm{Th}_{1}$, IL-12, INF- $\gamma$, TNF- $\alpha$ pelas células apresentadoras de antígenos e células $\mathrm{Th}_{1}$ e consequentemente aumentam a produção de citocinas $\mathrm{Th}_{2}$, IL-4, IL-10 e IL-13 pelas células $\mathrm{Th}_{2}$ (BARNES, 1997).

O estresse esta associado à exacerbação da asma. A percepção do estresse por um indivíduo geralmente provoca a ativação do eixo HPA e a subsequente liberação de glicocorticóides e de catecolaminas. Portanto, parece um paradoxo que o tratamento para os sintomas da asma envolva, geralmente, a administração de glicocorticóides ou de beta agonistas do tipo 2, uma vez que estes compostos são potentes broncodilatadores. Contudo, o efeito dos glicocorticóides e das catecolaminas sobre a asma é complexo e farmacológico em dose; sendo assim, o estresse pode ser considerado como um fator atenuador ou exacerbador dos sintomas da asma. $\mathrm{O}$ fato de que diferentes tipos de estressores (físico ou psicológico) podem provocar diferentes respostas bioquímicas e fisiológicas são parcialmente responsáveis por algumas destas diferentes ações dos glicocorticóides e das catecolaminas sobre as doenças atópicas. Além disso, Dhabhar (1997) demonstrou que a duração de um estressor pode diferencialmente afetar a resposta imunológica. O estresse agudo pode melhorar a resposta imune mediada por células, mas em contraste, o mesmo estressor aplicado cronicamente suprime a resposta imune mediada por células (DHABHAR; MCEWEN, 1997).

Trabalho de Ligeiro de Oliveira et al. (2004) mostrou que ratos sensibilizados e desafiados com OVA, e tratados com anfetamina, um potente estressor químico (CONNOR, 2004; DE OLIVEIRA et al., 2011; HAMASATO et al., 2013), apresentaram uma diminuição na população de leucócitos no pulmão e no sangue periférico e um aumento no número de células na medula óssea; estes achados foram interpretados como sendo decorrência de uma ativação do eixo HPA com consequente liberação de corticosterona. De fato, o pré tratamento dos animais sensibilizados com metirapona, um fármaco inibidor da síntese de corticosterona, reverteu parcialmente os efeitos induzidos pela anfetamina na migração de células inflamatórias no modelo de inflamação alérgica pulmonar.

Como discutido acima, um dos mecanismos mais relevantes da modulação da resposta imune pelo estresse se faz via ativação do eixo HPA, desenvolvendo-se por alterações no balanço de citocinas de perfil $\mathrm{Th}_{1} / \mathrm{Th}_{2}$. Basicamente o que diferencia as duas populações de linfócitos são as citocinas que liberam; os linfócitos $\mathrm{Th}_{1}$ (imunidade celular) caracterizam-se 
pela expressão de citocinas pró-inflamatórias, tais como interleucinas IL-2, IL-12, INF- $\gamma$ e TNF- $\alpha$, resultando em uma diferenciação de macrófagos, células natural killer (NK) e células $\mathrm{T}$ citotóxicas, que estão envolvidas na fagocitose e destruição de bactérias invasoras ou de corpos estranhos (BARNES, 1997). A imunidade $\mathrm{Th}_{2}$ (imunidade humoral) caracteriza-se pela produção de citocinas anti-inflamatórias, tais como IL-4, IL-9, IL-10 e IL-13, resultando na diferenciação de eosinófilos, mastócitos e células B, que leva a uma defesa orgânica a antígenos, mediada por anticorpos (WILLS-KARP et al., 1996). Então, quando produzidas, IL-12 e TNF- $\alpha$ aumentam a resposta imune inata ou $\mathrm{Th}_{1}$ e inibem as respostas do tipo humoral ou $\mathrm{Th}_{2}$ (SCHUIJS et al., 2013). A IL-4 e a IL-10 produzem efeito oposto, ou seja, deslocam o equilíbrio $\mathrm{Th}_{1} / \mathrm{Th}_{2}$ para o padrão $\mathrm{Th}_{2}$. No caso de um estresse agudo, via secreção de glicocorticóides há um favorecimento das respostas do tipo $\mathrm{Th}_{2}$ (BARNES, 1997). Eles inibem a produção de IL-12, INF- $\gamma$ e TNF- $\alpha$ por células apresentadoras de antígenos e células $\mathrm{Th}_{1}$, mas induzem um aumento da produção de IL-4, IL-10 e IL-13 por células $\mathrm{Th}_{2}$. Em decorrências, pode-se dizer que os glicocorticóides suprimem uma resposta imune celular do tipo $\mathrm{Th}_{1}$ e aumentam uma resposta humoral mediada por células $\mathrm{Th}_{2}$ (TRUEBA; RITZ, 2013), o que torna o indivíduo estressado mais susceptível a alergias e doenças auto-imunes mediadas por anticorpos.

Desta forma, pareceu-nos relevante abordar, dentro de uma perspectiva neuroimune, os efeitos da convivência com um conspecífico portador do tumor ascítico de Ehrlich sobre parâmetros imunes, neuroendócrinos e comportamentais de camundongos OVA sensibilizados e desafiados, o modelo experimental de inflamação alérgica pulmonar descrito acima. Mais especificamente, o presente estudo foi desenhado para analisar os efeitos da coabitação por 14 dias com um conspecífico portador do TAE considerando os seguintes parâmetros: tráfego celular para o LBA, produção de citocinas $\mathrm{Th}_{1} \mathrm{e} \mathrm{Th}_{2}$, níveis séricos de imunoglobulinas, expressão de moléculas de adesão em células do LBA, reatividade da traquéia, desgranulação de mastócitos, níveis de corticosterona e de catecolaminas plasmáticas, comportamento no campo aberto e no labirinto em cruz elevado e avaliação de citocinas no SNC. 


\section{OBJETIVOS}

\subsection{OBJETIVO GERAL}

Avaliar os efeitos da convivência com um conspecífico doente, portador de um tumor ascítico de Ehrlich, sobre parâmetros imunes, neuroendócrinos e comportamentais de camundongos OVA sensibilizados e desafiados, em um modelo experimental de inflamação alérgica pulmonar.

\subsection{OBJETIVOS ESPECÍFICOS}

Avaliar os efeitos da convivência por 14 dias com um conspecífico doente, portador de um tumor ascítico de Ehrlich sobre:

$\checkmark$ a contagem total e diferencial de leucócitos no LBA;

$\checkmark$ a contagem total de leucócitos no sangue periférico e na medula óssea;

$\checkmark$ a produção das citocinas IL-4, IL-5, IL-10, INF- $\gamma$ no sobrenadante do LBA;

$\checkmark$ a produção de imunoglobulinas IgE-OVA, IgG1-OVA e IgG2a-OVA específica no soro;

$\checkmark$ a expressão das moléculas de adesão ICAM-1, VCAM-1 e L-selectina em granulócitos do LBA;

$\checkmark$ a reatividade in vitro das vias aéreas por meio da análise da contração de traquéia isolada;

$\checkmark$ a desgranulação de mastócitos;

$\checkmark$ o peso relativo do baço, do timo e das glândulas adrenais; 
$\checkmark$ a atividade do eixo HPA por meio da dosagem dos níveis plasmáticos de corticosterona;

$\checkmark$ a atividade do SNS por meio da dosagem dos níveis plasmáticos de adrenalina e noradrenalina;

$\checkmark$ o comportamento no campo aberto;

$\checkmark$ o comportamento no labirinto em cruz elevado;

$\checkmark$ a expressão de citocinas (IL-1 $\beta$, IL-4, IL-5, IL-6, IL-13, IL-33) e de C-fos no núcleo paraventricular do hipotálamo (PVN), central da amígdala (CeA) e córtex pré-frontal (PFC). 


\section{MATERIAL E MÉTODOS}

\subsection{ANIMAIS}

Foram utilizados camundongos machos adultos da linhagem BALB/C, com 8-10 semanas de idade, provenientes de proles obtidas no Biotério do Departamento de Patologia da Faculdade de Medicina Veterinária e Zootecnia da Universidade de São Paulo (FMVZ USP). Os animais foram utilizados segundo as normas e procedimentos éticos relativos ao uso de animais de laboratório propostas pelo Comitê de Ética da FMVZ - USP (Protocolo $n^{\circ}$ 2595/2012). O máximo de esforço foi desprendido para minimizar possíveis desconfortos causados aos animais. Além disso, em todos os experimentos do presente trabalho foi empregada a filosófica dos "3Rs" (do inglês replace, reduce e refine), que tem como objetivo reduzir ao máximo o tamanho da amostra sem comprometer as análises estatísticas e a interpretação dos resultados.

Antes do início dos experimentos, e por um período mínimo de 7 dias, os animais foram alojados, em número de 2 em gaiolas de polipropileno $(28 \times 17 \times 12 \mathrm{~cm})$ para adaptação às condições ambientais e de manejo do biotério experimental. Estas gaiolas foram devidamente acondicionadas em salas cuja temperatura ambiente $\left(24\right.$ a $\left.26^{\circ} \mathrm{C}\right)$ e umidade (65 a $\left.70 \%\right)$ foram mantidas por meio de aparelhos de ar condicionado central, com ventilação, exaustão e luminosidade controladas, obedecendo-se a um ciclo claro - escuro de 12 horas, com início da fase clara às 7:00 horas. Os animais foram alimentados com ração balanceada para roedores (NUVILAB ${ }^{\circledR}$, Nuvital Nutrientes, Colombo, Paraná). Ração e água foram fornecidas aos animais ad libitum durante todo o período experimental. Após um período de adaptação foram realizados os experimentos descritos a seguir. 


\subsection{PROCEDIMENTOS EXPERIMENTAIS}

Os seguintes procedimentos experimentais foram realizados.

\subsubsection{Formação dos grupos experimentais}

Os animais foram separados em duplas de acordo com o peso corporal, sendo agrupados ao acaso em 3 grupos: controle, experimental e naïve. Um animal de cada dupla do grupo experimental foi inoculado no dia experimental $\mathrm{D}_{(0)}$ com uma suspensão de células do TAE $\left(5 \times 10^{6}\right.$ células/animal) pela via i.p.; o outro animal da dupla, o objeto do presente trabalho, foi chamado de "companheiro do animal doente" (CAD). Um animal de cada dupla do grupo controle foi injetado no dia experimental $\mathrm{D}_{(0)}$ com $0,1 \mathrm{~mL} / 10 \mathrm{~g}$ de PBS (salina tamponada com fosfato) pela via i.p.; o outro animal da dupla, foi chamado de "companheiro do animal saudável" (CAS). Os animais do grupo naïve não foram manipulados e permaneceram durante todo o período experimental em suas gaiolas moradia.

Durante todo o período de convivência $\left(\mathrm{D}_{0}\right.$ a $\left.\mathrm{D}_{14}\right)$, não se observou comportamento agressivo, bem como qualquer tipo de confrontamento ou de lesões indicativas de brigas nos camundongos. Neste sentido, a presença de comportamento agressivo e/ou de lesões produzidas por encontros agonísticos poderiam representar variáveis intercorrentes aos experimentos. Os animais injetados ou não com o tumor ascítico de Ehrlich foram analisados em suas gaiolas de moradia para registro dos sinais e sintomas eliciados pelo tumor ascítico de Ehrlich conforme tabela de escores proposta por Alves et al. (2010). Brevemente, os seguintes escores foram utilizados para classificar a severidade dos sintomas dos animais injetados com o TAE: 0, animais predominantemente ativos, sem sinais de doença; 1 , animais predominantemente ativos com apetite normal e presença de pelos arrepiados; 2, animais ativos, apetite normal e presença de um pequeno aumento de volume abdominal; 3 , animais ativos, apetite normal, presença de pelos arrepiados, e presença de um grande volume abdominal; 4, animais com ausência de atividade, anorexia, dispinéia, presença de pelos arrepiados, e um severo aumento de volume abdominal. $\mathrm{O}$ dia $\mathrm{D}_{(14)}$, o dia em que a maioria dos animais injetados com o tumor de Ehrlich apresentava o escore 4, foi escolhido para a 
realização dos experimentos com os companheiros dos animais doentes (CAD) e do saudável (CAS). Os animais do grupo $\mathrm{N}$ (naïve) foram utilizados para o controle dos parâmetros avaliados. A figura 1 ilustra este procedimento.

Figura 1 - Formação dos grupos experimental, controle e nä̈ve

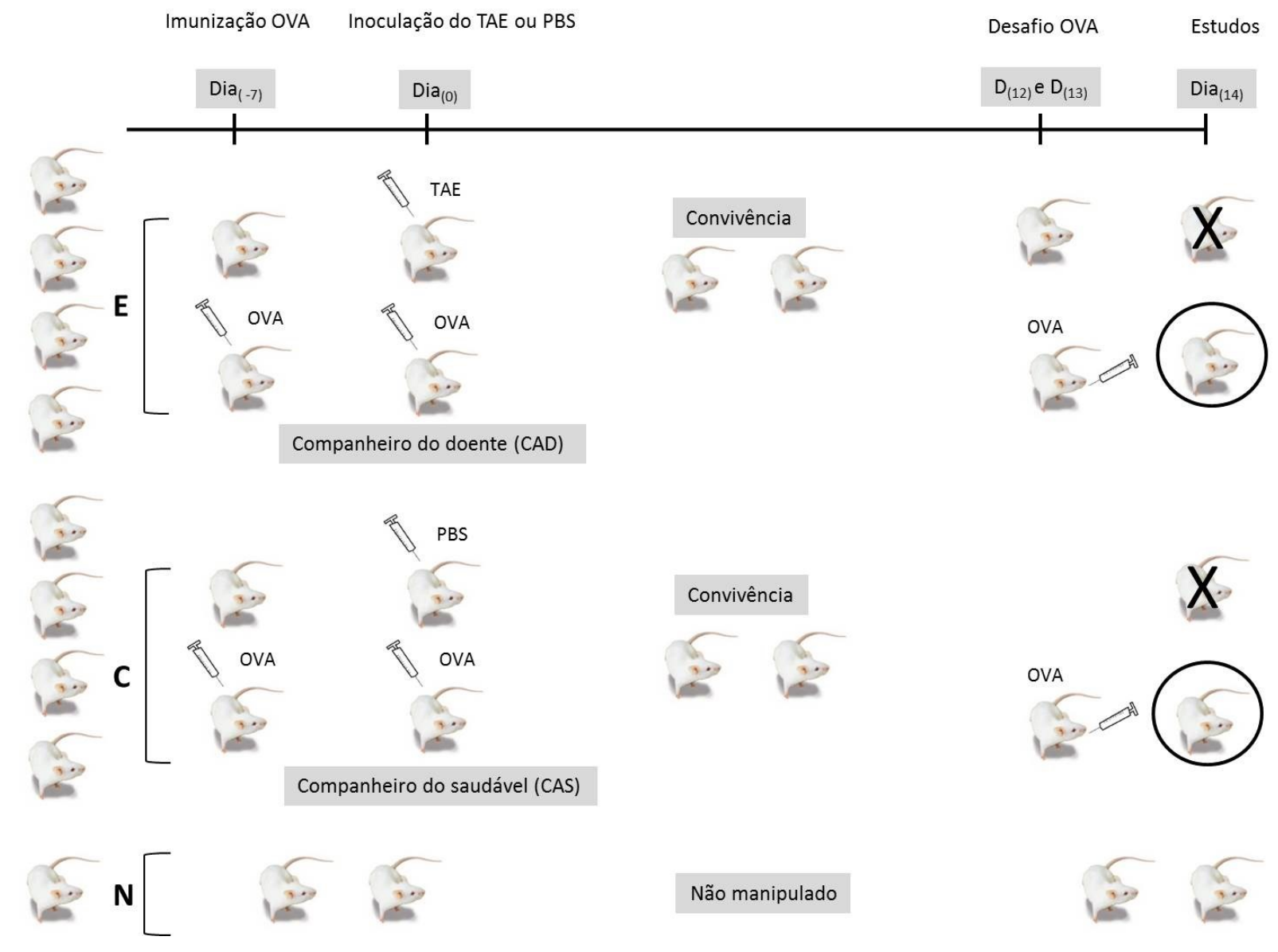

Fonte: (HAMASATO, E. K., 2015)

Legenda: Onde: C: grupo controle; E: grupo experimental; N: grupo naïve; PBS: 0,1 mL/10g de PBS; OVA: ovalbumina; TAE: $5 \times 10^{6}$ células/animal de tumor ascítico de Ehrlich. 
4.2.2 Modelo de inflamação alérgica pulmonar em camundongos

Os animais CAD e CAS foram imunizados no dia $\mathrm{D}_{(-7)}$ com $0,4 \mathrm{~mL}$ de uma solução de $10 \mu \mathrm{g}$ de ovalbumina (OVA) adsorvida em $10 \mathrm{mg}$ de hidróxido de alumínio em gel (Pierce Biotecnology, Rockford, IL, USA) diluídos em PBS administrada por via subcutânea (s.c.). No dia $\mathrm{D}_{(0)}$, estes animais receberam um reforço com a mesma dose desta solução pela via s.c.. O desafio com solução de OVA pela via intranasal foi realizado, nos dias $\mathrm{D}_{(12)}$ e $\mathrm{D}_{(13)}$ sendo os animais anestesiados pela via inalatória com isoflurano (Vetflurano, Virbac, São Paulo, Brasil). Os estudos foram realizados no dia $D_{(14)}$. As figuras 1 e 2 resumem o procedimento.

Figura 2 - Protocolo de indução da inflamação alérgica pulmonar em camundongos

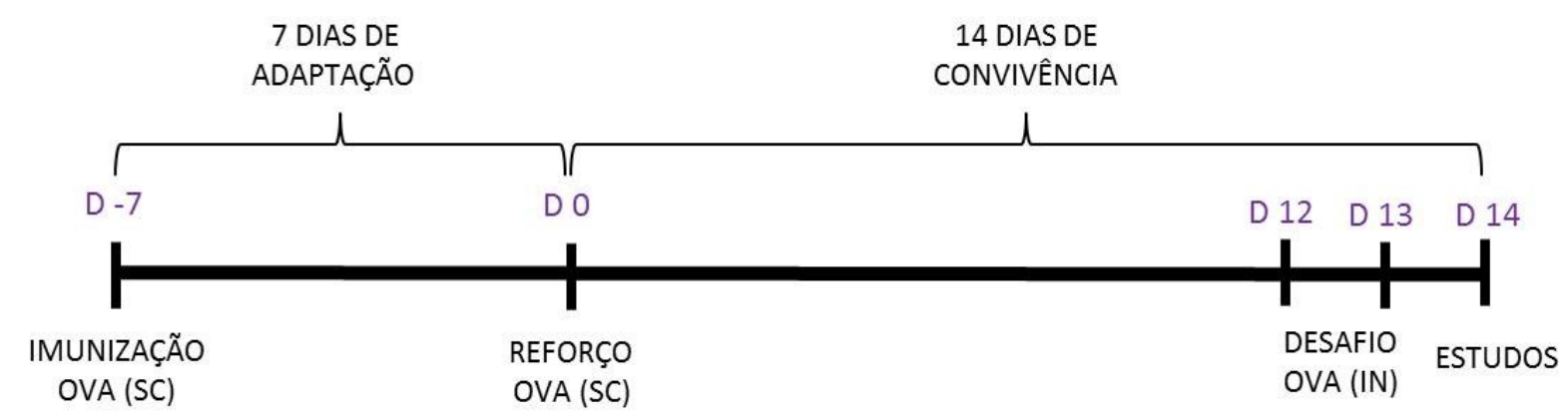

Fonte: (HAMASATO, E. K., 2015)

Legenda: $D_{(-7)}$ : imunização. $D_{(0)}$ : reforço. $D_{(12)}$ e $D_{(13)}$ : desafio. $D_{(14)}$ : coleta das amostras. SC: injeção subcutânea. IN: instilação intranasal.

4.2.3 Obtenção e manutenção de células do tumor ascítico de Ehrlich

Após a eutanásia em câmara de $\mathrm{CO}_{2}$, procedeu-se à colheita do fluído ascítico de um camundongo doador, portador de um tumor ascítico de Ehrlich com 7 dias de evolução. A suspensão de células obtidas deste animal foi centrifugada a $1000 \mathrm{~g}$, por 5 minutos sendo ressuspensa por três vezes em PBS. Realizou-se, então, a contagem e avaliação da viabilidade das células tumorais assim obtidas usando-se para tal o azul de Tripan (1:200) e empregandose uma câmara de Neubauer. Foi padronizado para uso nos camundongos chamados "doentes" 
nos experimentos deste trabalho um total de $5 \times 10^{6}$ células tumorais por $\mathrm{ml}$ de PBS, com no mínimo $90 \%$ de viabilidade. Para manutenção in vivo do tumor no laboratório, $0,1 \mathrm{ml}$ de fluído ascítico de um camundongo doador foi inoculado semanalmente em um camundongo receptor. Estes procedimentos foram realizados conforme descrito por Alves et al. (2007).

4.2.4 Contagem total e diferencial de leucócitos do lavado broncoalveolar (LBA)

Para a coleta do LBA os animais foram profundamente anestesiados (Xilazina $20 \mathrm{mg} / \mathrm{Kg}$ + Ketamina $100 \mathrm{mg} / \mathrm{Kg}$; i.p.) e sacrificados por exsanguinação via aorta abdominal, 24 horas após o último desafio com OVA no dia $\mathrm{D}_{(14)}$. Os pulmões foram lavados com alíquotas de 1,5 mL de PBS através de uma cânula inserida por traqueostomia. O fluido do LBA foi retirado e centrifugado a $1200 \mathrm{~g}$ por $10 \mathrm{~min}$. O pellet de células foi ressuspendido em $1 \mathrm{~mL}$ de PBS. A contagem de leucócitos totais foi realizada após a adição de $10 \mu \mathrm{L}$ de azul de Trypan a $90 \mu \mathrm{L}$ da suspensão celular. Câmaras de Neubauer foram utilizadas para a contagem celular. A contagem diferencial, da suspensão celular foi realizada utilizando-se uma citocentrífuga Citospin (FANEM, São Paulo, Brasil), após coloração de Rosenfeld, empregando-se critérios morfológicos.

\subsubsection{Contagem de leucócitos do sangue periférico}

Para a coleta do sangue os mesmos animais que haviam sido profundamente anestesiados, tiveram uma alíquota de sangue retirada da aorta abdominal, com o auxílio de seringas e agulhas previamente umedecidas com EDTA 10\%. A contagem de leucócitos totais foi determinada utilizando-se o contador de células ABC-Vet (Horiba ABX ${ }^{\circledR}$, Montpellier, França) de uso veterinário. 
4.2.6 Contagem da celularidade da medula óssea

Para determinar a celularidade da medula óssea, foi utilizado o fêmur direito de cada animal anteriormente anestesiado. O conteúdo da medula óssea foi lavado com $5 \mathrm{~mL}$ de PBS e a suspensão resultante foi acondicionada em tubos de polipropileno de $10 \mathrm{~mL}$, dentro de um banho de gelo. Imediatamente após, realizou-se a contagem por meio de uma Câmara de Neubauer (diluição 1:200), sendo a viabilidade celular das mesmas observadas por coloração com azul de Trypan, aceitando o mínimo 95\% de viabilidade.

4.2.7 Quantificação de citocinas no sobrenadante do LBA e imunoglobulinas no soro

A quantificação das citocinas no pulmão foi realizada no sobrenadante do LBA e a quantificação das imunoglobulinas no soro, ambos obtidos de animais sensibilizados, as coletas foram realizadas, 24 horas após o último desafio antigênico, isto é, no dia $\mathrm{D}_{(14)}$. As dosagens de citocinas e imunoglobulinas foram realizadas por ELISA, utilizando-se os kits OptEIA para citocinas (BD Biosciences, San Jose, CA, USA). Neste método, placas de 96 poços foram sensibilizadas com $50 \mu \mathrm{L}$ por poço de anticorpo de captura diluído em tampão PBS e incubados por uma noite. Após 3 lavagens com $300 \mu \mathrm{L} /$ poço de tampão de lavagem, as placas foram bloqueadas com $200 \mu \mathrm{L}$ /poço de tampão de bloqueio por 60 minutos à temperatura ambiente. Após 3 lavagens sucessivas, as amostras foram incubadas por um período de 2 horas em temperatura ambiente. Para realização da curva padrão, as citocinas foram incubadas em duplicata $(50 \mu \mathrm{L} /$ poço) e diluídas em série, conforme recomendações do fabricante. Após cinco lavagens $50 \mu \mathrm{L} /$ poço do anticorpo de detecção foram adicionados, seguindo-se incubação por 60 minutos à temperatura ambiente e no escuro. Novamente, a placa foi lavada sete vezes e $50 \mu \mathrm{L} /$ poço de estreptoavidina foram adicionados em cada um deles, sendo as placas incubadas por 20 minutos, no escuro, em temperatura ambiente. Por fim, adicionaram-se $50 \mu \mathrm{L}$ /poço de $\mathrm{H}_{2} \mathrm{SO}_{4}(2 \mathrm{~N})$ para interromper a reação e a densidade óptica foi determinada em um espectofotômetro com filtro de $450 \mathrm{~nm}$. O limite de detecção da IL-4, IL-5 e IL-10 foi de $15.6 \mathrm{pg} / \mathrm{mL}$ e aquele do INF- $\gamma$ de $2 \mathrm{pg} / \mathrm{mL}$. 
4.2.8 Quantificação da expressão das moléculas de adesão celular ICAM-1, VCAM-1 e Lselectina em leucócitos do LBA

A expressão das moléculas de adesão celular ICAM-1, VCAM-1 e L-selectina foi determinada em amostras de células coletadas do LBA conforme descrito no item 4.2.4. As células provenientes do LBA foram ressuspensas em meio de cultura DMEN (Dulbeccomodified Eagle's médium) contendo 2\% de FCS (Fetal calf serum). 1 x 10 $10^{6}$ células $/ 25 \mu 1$ foram incubadas com o anticorpo anti-CD16/CD32 (na diluição de $1: 100$ ) por 20 min a $4^{\circ} \mathrm{C}$ pra bloquear as ligações não-específicas via receptor Fc. Após lavagem com tampão de FACs, essas células foram incubadas com $0,25 \mu \mathrm{g}$ dos seguintes anticorpos: FITC (VCAM-1) (detector FL1), PE (ICAM-1) e PE-Cy (L-selectina) (detector FL2) por 30 min a $4^{\circ} \mathrm{C}$ de acordo com as especificações do fabricante. Em seguida as células marcadas com os anticorpos foram ressuspensas em $500 \mu \mathrm{L}$ de paraformaldeído (1\%) e acondicionadas a $4^{\circ} \mathrm{C}$ para leitura no citômetro de fluxo FACalibur (BD Bioscience,San Diego, CA, USA). Os dados foram analisados usando-se o software FlowJo (Tree Star, Ashland, EUA) e os resultados foram expressos em porcentagem de células positivas para a molécula avaliada.

4.2.9 Avaliação da reatividade das vias aéreas in vitro através de traquéia isolada

Os animais foram profundamente anestesiados (Xilazina 20mg/Kg + Ketamina 100 $\mathrm{mg} / \mathrm{Kg}$; i.p.) e exsangüinados através da secção da aorta abdominal e a seguir tiveram seu tórax aberto. A traquéia foi isolada e o tecido conjuntivo adjacente removido. A seguir, segmentos de traquéia foram montados para registro isométrico de contrações em cubas próprias para estudos em órgão isolado $(15 \mathrm{~mL})$ contendo solução de Krebs-Henseleit aerada com $95 \% \mathrm{O}_{2}$ e 5\% $\mathrm{CO}_{2}$ com a seguinte composição (nM): $\mathrm{NaCl}, 115.0 ; \mathrm{KCl}, 4.6 ; \mathrm{CaCl}_{2} 2$. $\mathrm{H}_{2} \mathrm{O}, 2,5 ; \mathrm{KH}_{2} \mathrm{PO} 4,1.2 ; \mathrm{MgSO}_{4} .7 \mathrm{H}_{2} \mathrm{O}, 2,5 ; \mathrm{NaHCO}_{3}, 25.0$ e glicose 11.0. O registro da força isométrica foi realizado utilizando o sistema POWER LAB 4sp (AD Instruments, Melbourne, Austrália) e transdutores isométricos (F-60), utilizando-se para análise o programa Chart 3.4 (AD Instruments, Melbourne, Austrália). 
4.2.10 Fixação, processamento e inclusão do tecido pulmonar para avaliação da desgranulação de mastócitos

Os animais tiveram a traquéia canulada e os pulmões insuflados com $1 \mathrm{~mL}$ de ar. Em seguida, os brônquios foram amarrados para evitar a perda de ar e o pulmão foi fixado em uma solução contendo paraformaldeído a $2 \%$ e glutaraldeído a $2 \%$ em tampão fosfato Sorensen $0,1 \mathrm{M}, \mathrm{pH} 7,4$, por $24 \mathrm{~h}$, a $4^{\circ} \mathrm{C}$. As amostras foram lavadas no mesmo tampão, desidratadas em soluções crescentes de etanol, clarificadas em xilol e incluídas em parafina. Cortes de $3 \mu \mathrm{m}$ foram realizados no micrótomo Hyrax M60 (Zeiss, Munique, Alemanha) sendo, posteriormente, corados com solução de azul de toluidina $0,25 \%$ e borato de sódio a $0,25 \%$ para análise histológica. As amostras (10 cortes por animal, 5 animais por grupo, $\mathrm{n}=$ 50 por grupo) foram avaliadas ao microscópio (AxioScope.A1, Zeiss, Munique, Alemanha). Os cortes histológicos foram analisados por morfometria através do Software Axiovision (Zeiss, Munique, Alemanha) para determinação das áreas teciduais e contagem dos mastócitos. As células foram expressas em média \pm erro padrão por $\mathrm{mm}^{2}$ de tecido pulmonar.

\subsubsection{Peso relativo de tecidos periféricos (baço, adrenais e timo)}

No dia experimental $\mathrm{D}_{(14)}$ os animais foram pesados e após eutanásia foram deles retirados cirurgicamente via abertura da cavidade abdominal o baço, as glândulas adrenais direita e esquerda e o timo. Os tecidos foram pesados em balança de precisão para análise do peso relativo do órgão (peso do tecido/ peso total do animal).

4.2.12 Dosagem dos níveis plasmáticos de corticosterona

O sangue dos animais foi coletado pelo plexo submandibular, sendo centrifugado (2000 g/20 minutos) para obtenção do plasma. Este foi armazenado em eppendorfs de polietileno em freezer $-80{ }^{\circ} \mathrm{C}$ até o momento da realização das dosagens hormonais conforme 
proposto pelo fabricante. As dosagens para quantificação de corticosterona foram realizadas por ensaio imunoenzimático (ELISA) utilizando-se o kit comercial (Life Science, Plymouth Meeting, PA, USA). O limite de detecção da corticosterona foi de 27.0 pg/mL.

\subsubsection{Dosagem dos níveis plasmáticos de catecolaminas}

O sangue dos animais foi coletado pelo plexo submandibular e imediatamente congelado em nitrogênio líquido para evitar a degradação das catecolaminas, sendo centrifugado (2000 g/20 minutos) para obtenção do plasma. Este foi armazenado em eppendorfs de polietileno em freezer $-80^{\circ} \mathrm{C}$ até o momento da realização das dosagens. Para as dosagens de noradrenalina e adrenalina foi utilizado um cromatógrafo líquido de alta eficiência (HPLC) acoplado a detector eletroquímico (HPLC-ED; Shimadzu Modelo 20A ED DECADE SDC). Para adrenalina o limite de detecção foi de $80 \mathrm{pg} / \mathrm{mL}$ e o limite de quantificação de $150 \mathrm{pg} / \mathrm{mL}$ e para noradrenalina, o limite de detecção foi de $100 \mathrm{pg} / \mathrm{mL}$ e limite de quantificação foi de $500 \mathrm{pg} / \mathrm{mL}$ de plasma.

\subsubsection{Medida da atividade locomotora no campo aberto}

O campo aberto empregado neste estudo consiste de uma arena redonda feita de madeira, pintada de preto $(40 \mathrm{~cm}$ de diâmetro e com paredes de $25 \mathrm{~cm}$ de altura, sendo o conjunto todo elevado a $55 \mathrm{~cm}$ do solo). A atividade locomotora dos animais foi avaliada por meio de observação indireta feita por meio de um sistema ETHOVISION XT (versão 7.0; Noldus Information Technology, Leesburg, EUA). Desta forma, a presença do observador não interferiu com os parâmetros observados, uma vez que este ficou fora da sala onde se encontravam os animais em teste. É importante ressaltar que a sala onde foi realizado o experimento era pouco iluminada e isolada de qualquer tipo de ruído. Os animais dos diferentes grupos foram intercalados entre si para evitar possíveis interferências do ritmo circadiano sobre os resultados. Cada animal foi colocado individualmente no centro da arena, sendo observado por 5 minutos. A avaliação da atividade foi feita sempre no mesmo período do dia (entre as 8:00 e 12:00 horas); entre as observações do animais, o aparelho foi limpo 
com uma solução aquosa de etanol 5\%, para evitar influência de odores deixados pelo animal anterior.

Os parâmetros indicativos de atividade locomotora medidos no presente estudo foram: (a) distância percorrida $(\mathrm{cm})$ : corresponde à distância total percorrida pelo animal na arena durante os 5 minutos de teste; (b) velocidade média $(\mathrm{cm} / \mathrm{s})$ : corresponde à média da distância percorrida pelo animal na arena por unidade de tempo; (c) tempo dispendido nas zonas central, intermediária e tigmotáxica (periférica) do campo aberto.

4.2.15 Medida de ansiedade por meio do labirinto em cruz elevado

Trata-se de um labirinto em forma de cruz feito de madeira e pintado na cor branca, constituído por dois braços abertos medindo $15 \mathrm{~cm}$ de comprimento por $5 \mathrm{~cm}$ de largura cada um, em oposição a dois braços fechados de iguais medidas, mas com paredes laterais com 15 cm de altura. $\mathrm{Na}$ intersecção dos braços abertos e fechados, forma-se um espaço de $25 \mathrm{~cm}^{2}$ de área denominado centro, sendo o conjunto todo elevado a $55 \mathrm{~cm}$ do solo. Os níveis de ansiedade dos animais foram avaliados por meio de uma observação indireta feita por intermédio do sistema ETHOVISION XT (versão 7.0; Noldus Information Technology, Leesburg, EUA) e realizado como descrito acima. Mais uma vez, os animais dos diferentes grupos foram intercalados para evitar possíveis interferências do ritmo circadiano sobre os resultados. Os animais foram colocados individualmente no centro do labirinto, sendo observados por 5 minutos. A avaliação da atividade comportamental foi realizada sempre no mesmo período do dia (entre as 8:00 e 12:00 horas). A arena foi limpa com uma solução aquosa de álcool a 5\% antes da introdução de cada animal para evitar possíveis efeitos de odores deixados pelo animal anterior.

A avaliação dos níveis de ansiedade dos animais no LCE foi realizada como descrito por (PELLOW et al., 1985) e validada para camundongos por (LISTER, 1987). Assim, após as filmagens, fez-se no software ETHOVISION divisões virtuais do LCE, isto é, dos braços abertos e dos braços fechados de forma tal a permitir a análise e o registro dos seguintes parâmetros: (a) distância percorrida $(\mathrm{cm})$, (b) velocidade média $(\mathrm{cm} / \mathrm{s})$, (c) número de entradas nos braços abertos (n), (d) número de entradas nos braços fechados (n), (e) tempo de permanência nos braços abertos (s) e (f) tempo de permanência nos braços fechados (s). A 
avaliação do comportamento no labirinto em cruz elevado foi feita imediatamente após o término das observações no campo aberto, colocando-se cada animal, individualmente, na área central do aparato, com a cabeça voltada para um dos braços fechados do LCE.

4.2.16 Análise da expressão gênica de citocinas no SNC

a) Coleta do tecido

O cérebro foi colhido após rápida decapitação dos animais, sendo imediatamente congelado em 2- metilbutano e armazenado em $-80^{\circ} \mathrm{C}$ para posterior punção cerebral. As estruturas de interesse (córtex pré frontal, núcleo paraventricular do hipotálamo e amigdala) foram identificadas com o auxílio de um atlas do cérebro de camundongo (PAXINOS; WATSON, 1998). Para punção das estruturas de interesse, o cérebro foi coronalmente cortado em criostato e punções das regiões de interesse foram acondicionadas em eppendorfs de polietileno em freezer $-80^{\circ} \mathrm{C}$ até o momento da realização do próximo procedimento.

\section{b) Extração de RNA e sintese da primeira cadeia}

O tecido foi homogeneizado utilizando-se Qiagen TissueLyser II (Qiagen, Valencia, CA,USA) durante 2-4 minutos a $20 \mathrm{~Hz}$ para assegurar a homogeneização completa das amostras. O RNA celular total foi extraído do tecido utilizando-se o mini kit Qiagen RNeasy (Qiagen, Valencia, CA,USA) de acordo com as instruções do fabricante. O RNA foi separado do sobrenadante por meio de extração com clorofórmio realizada após centrifugação a 12000 g durante 15 min a $4^{\circ} \mathrm{C}$. Um volume igual de etanol $70 \%$ foi adicionado ao RNA recolhido que foi purificado por meio de mini colunas RNeasy. As colunas foram lavadas e eluídas com $30 \mu \mathrm{L}$ de água isenta de RNA $\left(65^{\circ} \mathrm{C}\right)$. O rendimento e a pureza do RNA foram determinados utilizando-se o espectofotômetro NanoDrop 2000 (NanoDrop, Wilmington, USA). O RNA foi armazenado a $-80^{\circ} \mathrm{C}$ antes de ser usado para a síntese de cDNA.

\section{c) PCR em tempo real}

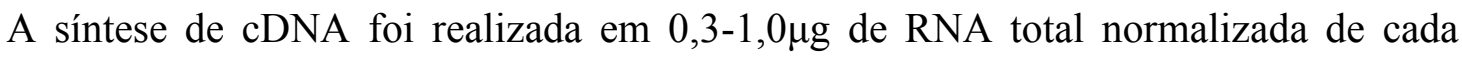
amostra utilizando-se o kit Quanti Tect de Transcrição Reversa (Qiagen, Valencia, CA, USA), que inclui um passo de tratamento de DNase. Todo o cDNA foi armazenado a $-20^{\circ} \mathrm{C}$ até o procedimento posterior. A amplificação do cDNA foi realizada por meio de uma reação com 
20 mL de uma solução composta por $10 \mu \mathrm{L}$ IQ SYBR Green supermix (Bio Rad Laboratories, Berkeley, CA, USA), $0,1 \mu \mathrm{L}$ de foward and reverse primers, $2 \mu \mathrm{L}$ de cDNA e $8,8 \mathrm{~mL}$ de água livre de ribonuclease. $\mathrm{O}$ estudo foi realizado em triplicata empregando-se uma placa de 384 poços (Bio Rad Laboratories, Berkeley, CA, USA) no termociclador Bio Had CFX 384 Sistema C 1000 em Tempo real (Bio Rad Laboratories, Berkeley, CA, USA). A expressão foi quantificada utilizando-se o método delta (2- $\Delta \Delta \mathrm{CT})$ tomada em relação ao gene de manutenção estável $\beta$-actina (LIVAK; SCHMITTGEN, 2001). Os genes de manutenção foram analisados separadamente para assegurar existência de estabilidade em todos os grupos de tratamento antes de sua utilização como referência.

\subsubsection{Análise estatística}

Os dados foram analisados pelo teste de Bartlet para determinação da homogeneidade das variâncias. Os dados paramétricos foram analisados pelo Teste-t de Student ou ANOVA de duas vias seguida do teste post hoc de Bonferroni quando apropriado. Quando não paramétricos, os resultados foram analisados pelo teste "U" de Nann-Whitney. Os resultados foram apresentados como média \pm erro padrão e foram considerados significantes todas as análises que revelaram nível de significância $p<0,05$. As análises estatísticas foram feitas com o auxílio do programa GraphPad Prism em sua versão 5.00 (GraphPad Softwares, La Jolla, CA, USA). 


\subsection{EXPERIMENTO $1-$ AVALIAÇÃO DOS EFEITOS INDUZIDOS PELA CONVIVÊNCIA POR 14 DIAS COM UM CONSPECÍFICO PORTADOR DO TAE SOBRE A MIGRAÇÃO CELULAR NO LBA, SANGUE PERIFÉRICO E MEDULA ÓSSEA}

Vinte e oito camundongos foram submetidos aos mesmos procedimentos descritos em 4.2.1 e 4.2.2; sendo eutanasiados 24 horas após o último desafio com OVA, isto é, no dia $\mathrm{D}_{(14)}$, para coleta de células do sangue, LBA e medula óssea para posterior contagem do número de leucócitos conforme descrito nos itens 4.2.4., 4.2.5., 4.2.6.

\section{Resultados}

A figura 3A ilustra os efeitos da convivência por 14 dias com um conspecífico portador do TAE sobre o número total de leucócitos do LBA de camundongos OVA sensibilizados e desafiados. A análise estatística dos dados obtidos mostrou a existência de diferenças significantes $(p<0.05)$ entre os grupos CAS e CAD. Mais especificamente, a convivência por 14 dias com portadores de um tumor aumentou $(F(2,21)=117,0 ; p<0.05)$ o número de leucócitos totais no LBA. Como mostra a figura $3 \mathbf{B}$, nenhuma diferença $(\mathrm{p}>0.05)$ foi detectada na contagem de células totais no sangue periférico dos animais dos grupos $\mathrm{N}$, CAS e CAD. Contudo, uma clara tendência para um aumento do número de leucócitos totais foi observada no grupo CAD. A figura 3C mostra que os camundongos dos grupos CAS e CAD apresentaram um aumento $(\mathrm{F}(2,21)=21,36 ; \mathrm{p}<0.05)$ do número de leucócitos totais na medula óssea em relação aos animais do grupo naïve. No entanto, observou-se uma diminuição $(\mathrm{p}<0.05)$ no número total de leucócitos totais na medula óssea dos animais do grupo $\mathrm{CAD}$ quando comparados àqueles do grupo CAS. 
Figura 3 - Efeitos da convivência por 14 dias com um conspecífico portador do TAE sobre o número de células totais do LBA (A), sangue periférico (B) e medula óssea (C) de camundongos OVA sensibilizados e desafiados
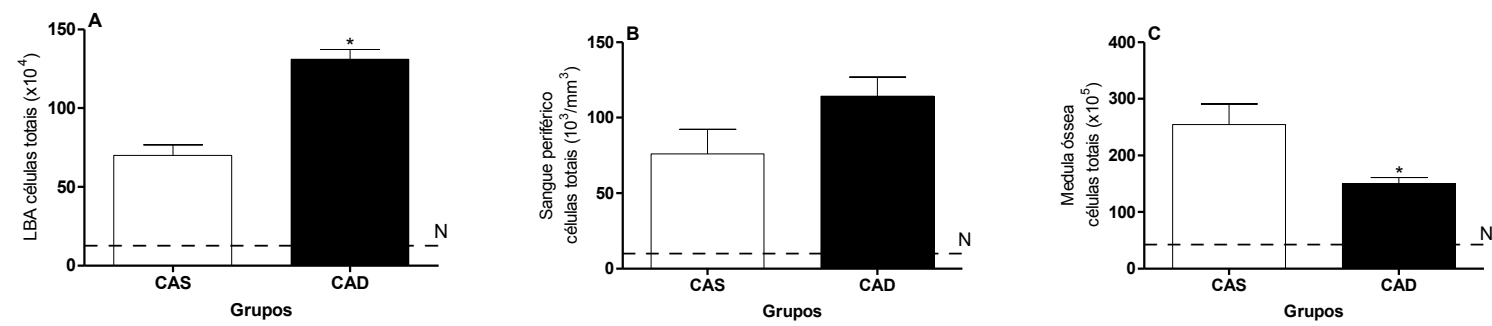

Legenda: Onde, CAS representa os animais companheiros dos animais saudáveis e CAD os animais companheiros dos animais doentes e a linha pontilhada indica valores de animais nä̈ve $(\mathrm{N}) .{ }^{*} \mathrm{p}<0,05$ representa diferença quando comparado com o grupo CAS. Os dados representam média \pm erro padrão de 7 animais por grupo

A tabela 1 mostra os efeitos da convivência por 14 dias com um conspecífico portador do TAE sobre a contagem diferencial de leucócitos do LBA de camundongos OVA sensibilizados e desafiados. A sensibilização e desafio com OVA aumentaram o número de eosinófilos e neutrófilos colhidos no LBA. Análises estatísticas adicionais dos dados obtidos mostraram a existência de diferenças significantes $(\mathrm{p}<0.05)$ entre os grupos CAS e CAD. Mais especificamente, a convivência por 14 dias com um conspecífico portador do TAE aumentou o número de eosinófilos $(\mathrm{F}(2,21)=80,09 ; \mathrm{p}<0.05)$ e neutrófilos $(\mathrm{F}(2,21)=127,70$; $\mathrm{p}<0.05)$ no LBA. Não observamos diferenças significantes $(\mathrm{p}>0.05)$ no número de células mononucleares no LBA entre os animais dos grupos N, CAS e CAD. 
Tabela 1 - Efeitos da convivência por 14 dias com um conspecífico portador do TAE sobre a contagem diferencial de leucócitos do LBA de camundongos OVA sensibilizados e desafiados

\begin{tabular}{|c|c|c|c|}
\hline Grupos & $\begin{array}{l}\text { Eosinófilos } \\
\qquad\left(\mathbf{1 0}^{5}\right)\end{array}$ & $\begin{array}{c}\text { Neutrófilos } \\
\left(\times 10^{5}\right)\end{array}$ & $\begin{array}{l}\text { Células mononucleares } \\
\qquad\left({\left.\mathrm{x} 10^{6}\right)}^{6}\right.\end{array}$ \\
\hline $\mathrm{N}$ & $0,00 \pm 0,00$ & $9,50 \pm 2,60$ & $4,80 \pm 0,60$ \\
\hline CAS & $2,71 \pm 0,88$ & $38,33 \pm 5,71$ & $4,50 \pm 0,92$ \\
\hline CAD & $5,10 \pm 0,83^{*}$ & $55,97 \pm 6,18^{*}$ & $5,11 \pm 0,76$ \\
\hline
\end{tabular}

Notas: CAS representa os animais companheiros dos animais saudáveis e CAD os animais companheiros dos animais doentes e $\mathrm{N}$ os animais naïve. ${ }^{*} \mathrm{p}<0,05$ representa diferença quando comparado com o grupo CAS. Os dados representam média \pm erro padrão de 7 animais por grupo

\subsection{EXPERIMENTO 2 - AVALIAÇÃO DOS EFEITOS INDUZIDOS PELA CONVIVÊNCIA POR 14 DIAS COM UM CONSPECÍFICO PORTADOR DO TAE SOBRE OS NÍVEIS DAS CITOCINAS IL-4, IL-5, IL-10 E IFN- $\gamma$ NO SOBRENADANTE DO LBA}

Vinte camundongos foram submetidos aos mesmos procedimentos descritos em 4.2.1 e 4.2.2; os animais foram eutanasiados 24 horas após o último desafio com OVA, isto é, no dia $\mathrm{D}_{(14)}$, sendo então coletado o LBA para posterior determinação da produção de citocinas conforme descrito no item 4.2.7.

\section{Resultados}

A figura 4 ilustra os efeitos da convivência por 14 dias com um conspecífico portador do TAE sobre a produção de citocinas no sobrenadante do LBA de camundongos OVA sensibilizados e desafiados. Observa-se que a sensibilização e o desafio com OVA aumentaram a produção de citocinas nos grupos CAS e CAD. A análise estatística dos dados obtidos mostrou existência de diferenças significantes $(p<0.05)$ entre os grupos CAS e CAD. Mais especificamente, a convivência por 14 dias com um conspecífico portador do TAE aumentou a produção de IL-4 $(\mathrm{F}(2,21)=54,47$; $<<0.05$, figura $4 \mathrm{~A})$ e IL-5 $(\mathrm{F}(2,21)=16,11$; 
$\mathrm{p}<0.05$, figura 4B) e diminuiu aquela de IL-10 $(\mathrm{F}(2,21)=24,33 ; \mathrm{p}<0.05$, figura $4 \mathrm{C})$ e IFN- $\gamma$ $(\mathrm{F}(2,21)=4,83 ; \mathrm{p}<0.05$, figura $4 \mathrm{D})$ em relação aos animais do grupo $\mathrm{N}$ e CAS.

Figura 4 - Efeitos da convivência por 14 dias com um conspecífico portador do TAE sobre a produção de IL-4 (A), IL-5 (B), IL-10 (C) e INF- $\gamma$ (D) no sobrenadante do LBA de camundongos OVA sensibilizados e desafiados
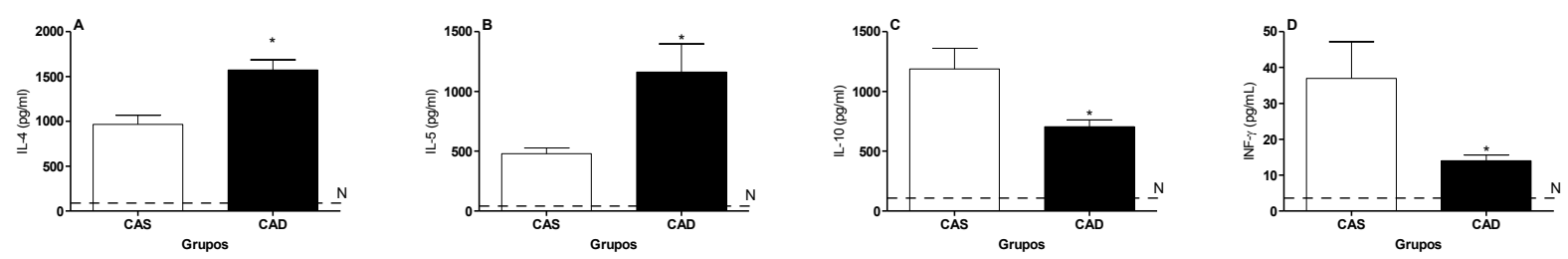

Legenda: Onde, CAS representa os animais companheiros dos animais saudáveis e CAD os animais companheiros dos animais doentes e a linha pontilhada indica valores de animais naïve (N). ${ }^{*} \mathrm{p}<0,05$ representa diferença quando comparado com o grupo CAS. Os dados representam média \pm desvio padrão de 5 animais por grupo

\subsection{EXPERIMENTO 3 - AVALIAÇÃO DOS EFEITOS INDUZIDOS PELA CONVIVÊNCIA POR 14 DIAS COM UM CONSPECÍFICO PORTADOR DO TAE SOBRE OS NÍVEIS DAS IMUNOGLOBULINAS IGE-OVA, IGG1-OVA E IGG2A- OVA NO SORO}

Foram empregados os mesmos camundongos usados no experimento 2, isto é, submetidos aos mesmos procedimentos descritos em 4.2.1 e 4.2.2; os animais foram eutanasiados 24 horas após o último desafio com OVA, isto é, no dia $\mathrm{D}_{(14)}$, sendo então deles coletado o sangue para posterior determinação dos níveis de imunoglobulinas conforme descrito no item 4.2.7. 


\section{Resultados}

A figura 5 ilustra os efeitos da convivência por 14 dias com um conspecífico portador do TAE sobre os níveis de imunoglobulinas no soro de camundongos OVA sensibilizados e desafiados. A análise estatística dos dados obtidos mostrou a existência de diferenças significantes $(p<0.05)$ entre os grupos CAS e CAD. Mais especificamente, observou-se um aumento de $\operatorname{IgG1-OVA}(\mathrm{F}(2,21)=57,11 ; \mathrm{p}<0.05$, figura $5 \mathrm{~A})$ e uma diminuição de $\operatorname{IgG} 2 \mathrm{a}-$ OVA $(\mathrm{F}(2,21)=102,30 ; \mathrm{p}<0.05$, figura $5 \mathrm{~B})$. Não se verificaram diferenças significantes ( $p>0,05$, figura 5C) nos níveis de IgE-OVA entre os animais dos grupos CAS e CAD. Como esperado, IgG1-OVA, IgG2a-OVA e IgE-OVA não foram detectadas nos animais do grupo N.

Figura 5 - Efeitos da convivência por 14 dias com um conspecífico portador do TAE sobre os níveis de IgG1OVA (A), IgG2a-OVA (B) e IgE-OVA (C) no soro de camundongos OVA sensibilizados e desafiados
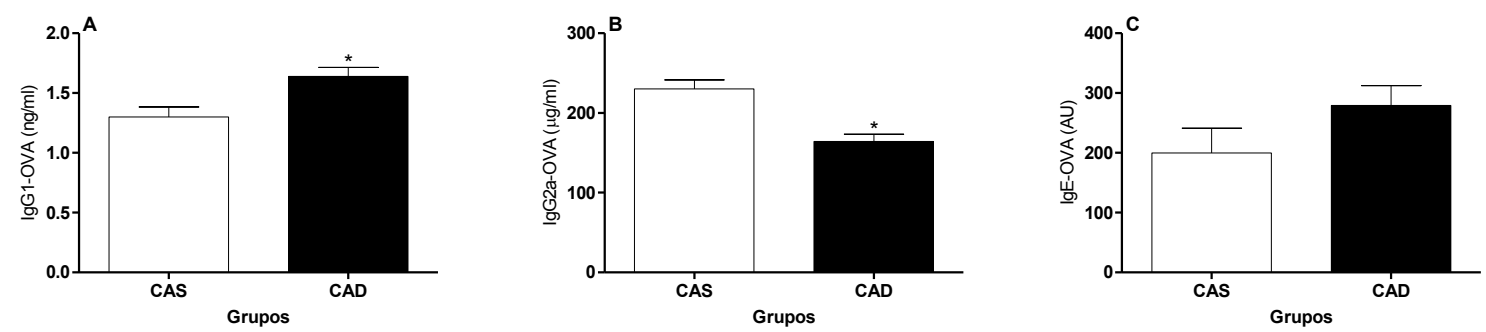

Legenda: CAS representa os animais companheiros dos animais saudáveis e CAD os animais companheiros dos animais doentes. Os dados representam média \pm erro padrão de 5 animais por grupo. 


\subsection{EXPERIMENTO $4-$ AVALIAÇÃO DOS EFEITOS INDUZIDOS PELA CONVIVÊNCIA POR 14 DIAS COM UM CONSPECÍFICO PORTADOR DO TAE SOBRE A EXPRESSÃO DAS MOLÉCULAS DE ADESÃO CELULAR ICAM-1, VCAM-1 E L-SELECTINA EM GRANULÓCITOS DO LBA}

Trinta e dois camundongos foram submetidos aos mesmos procedimentos descritos em 4.2.1 e 4.2.2; os animais foram eutanasiados 24 horas após o último desafio com OVA, isto é, no dia $\mathrm{D}_{(14)}$, sendo então deles coletado o LBA para posterior determinação da expressão das moléculas de adesão celular ICAM-1, VCAM-1 e L-selectina conforme descrito no item 4.2.8.

\section{Resultados}

A figura 6 ilustra os efeitos da convivência por 14 dias com um conspecífico portador do TAE sobre a expressão das moléculas de adesão ICAM-1 (A), VCAM-1 (B) e L-selectina (C) em granulócitos do LBA de camundongos OVA sensibilizados e desafiados. Como se observa, a sensibilização e o desafio com OVA produziram um aumento na expressão das moléculas de adesão avaliadas. A análise estatística dos dados obtidos mostrou existência de diferenças significantes $(\mathrm{p}<0.05)$ entre os grupos CAS e CAD. Mais especificamente, a convivência por 14 dias com um conspecífico portador do TAE aumentou a expressão de ICAM-1 $\left(\mathrm{F}_{(2,21)}=47,21 ; \mathrm{p}<0.05\right)$, VCAM-1 $\left(\mathrm{F}_{(2,21)}=76,05 ; \mathrm{p}<0.05\right)$ e L-selectina $\left(\mathrm{F}_{(2,21)}=\right.$ 22,55; $<<0.05)$ em granulócitos do LBA. 
Figura 6 - Efeitos da convivência por 14 dias com um conspecífico portador do TAE sobre a expressão das moléculas de adesão celular ICAM-1 (A), VCAM-1 (B) e L-selectina (C) em granulócitos do LBA de camundongos OVA sensibilizados e desafiados
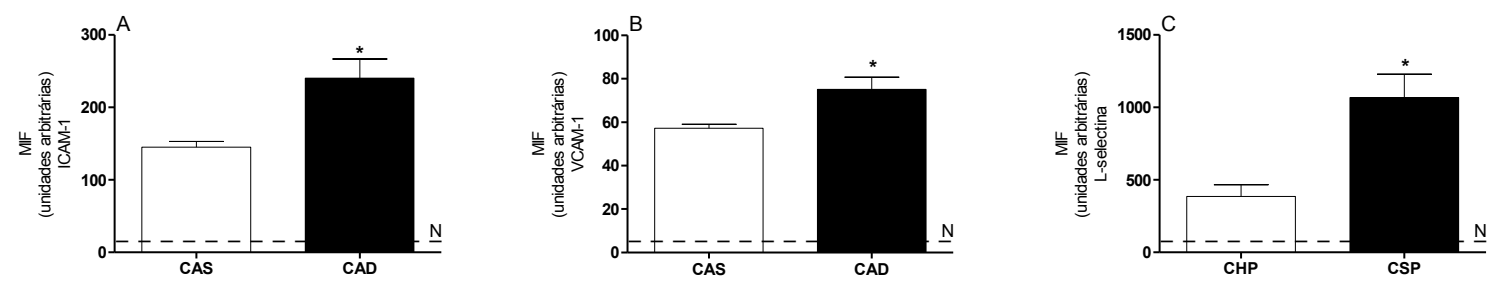

Legenda: Onde, CAS representa os animais companheiros dos animais saudáveis e CAD os animais companheiros dos animais doentes e a linha pontilhada indica valores de animais naïve $(\mathrm{N}) .{ }^{*} \mathrm{p}<0,05$ representa diferença quando comparado com o grupo CAS. Os dados representam média \pm erro padrão de 8 animais por grupo

\subsection{EXPERIMENTO 5 - AVALIAÇÃO DOS EFEITOS INDUZIDOS PELA CONVIVÊNCIA POR 14 DIAS COM UM CONSPECÍFICO PORTADOR DO TAE SOBRE A REATIVIDADE IN VITRO DA TRAQUÉIA À METACOLINA}

Trinta e dois camundongos foram submetidos aos mesmos procedimentos descritos em 4.2.1 e 4.2.2; os animais foram eutanasiados 24 horas após o último desafio com OVA, isto é, no dia $\mathrm{D}_{(14)}$, sendo então deles coletada a traquéia para análise de sua reatividade in vitro à metacolina conforme descrito no item 4.2.9.

\section{Resultados}

$\mathrm{O}$ teste ANOVA de duas vias mostrou a existência de diferenças significantes $\left(\mathrm{F}_{(2,6,147)}=52,81 \mathrm{p}<0.05\right)$ entre: os três grupos, as cinco diferentes doses de metacolina e a interação entre os efeitos da metacolina e entre os grupos. Como mostra a figura 7, a reatividade da traquéia à metacolina foi maior nos animais dos grupos CAS e CAD em relação ao grupo $\mathrm{N}(\mathrm{p}<0.05)$. Análise adicional mostra que a hiperreatividade da traquéia à metacolina foi reduzida nos animais do grupo $\mathrm{CAD}$ quando comparada àquela mensurada no grupo CAS ( $\mathrm{p}>0.05)$. Além disso, a curva dose- resposta para a metacolina foi deslocada para a direita e a contração máxima atingida foi menor nos animais do grupo $\mathrm{CAD}$ em relação àqueles do grupo $\mathrm{CAS}(\mathrm{p}<0.05)$. 
Figura 7 - Efeitos da convivência por 14 dias com um conspecífico portador do TAE sobre a reatividade in vitro da traquéia à metacolina de camundongos OVA sensibilizados e desafiados

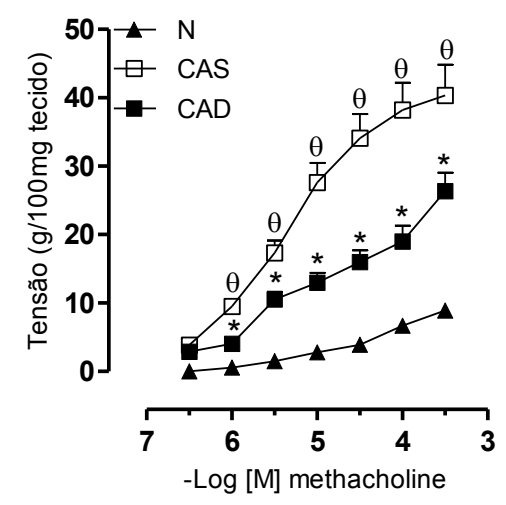

Legenda: Onde, CAS representa os animais companheiros dos animais saudáveis, CAD os animais companheiros dos animais doentes e $\mathrm{N}$ os animais do grupo nä̈ve. ${ }^{*} \mathrm{p}<0,05$ representa diferença quando comparado com o grupo CAS e $\mathrm{N}$. Os dados representam média \pm erro de 8 animais por grupo

\subsection{EXPERIMENTO $6-$ AVALIAÇÃO DOS EFEITOS INDUZIDOS PELA CONVIVÊNCIA POR 14 DIAS COM UM CONSPECÍFICO PORTADOR DO TAE SOBRE A DESGRANULAÇÃO DE MASTÓCITOS}

Vinte camundongos foram submetidos aos procedimentos descritos em 4.2.1 e 4.2.2; os animais foram eutanasiados 24 horas após o último desafio com OVA, isto é, no dia $\mathrm{D}_{(14)}$, sendo deles coletados os pulmões para posterior análise da desgranulação de mastócitos conforme descrito no item 4.2.10.

\section{Resultados}

A tabela 2 mostra os efeitos da convivência por 14 dias com um conspecífico portador do TAE sobre a desgranulação de mastócitos de camundongos OVA sensibilizados e desafiados. A análise estatística dos dados obtidos mostrou a existência de diferenças significantes $(\mathrm{p}<0.05)$ entre os grupos CAS e CAD. Mais especificamente, a convivência por 14 dias com um conspecífico portador do TAE aumentou o número de mastócitos desgranulados no pulmão. A figura 8 ilustra estes resultados. 
Tabela 2 - Efeitos da convivência por 14 dias com um conspecífico portador do TAE sobre a presença de mastócitos intactos, desgranulados, porcentagem relativa e total número de mastócitos pulmonares de camundongos OVA sensibilizados e desafiados

\begin{tabular}{ccccc}
\hline Grupos & Intacto & Desgranulado & $\%$ & Total \\
\hline CAS & $2,1 \pm 0,2$ & $0,5 \pm 0,2$ & 19,2 & $2,6 \pm 0,4$ \\
CAD & $0,5 \pm 0,2$ & $2,0 \pm 0,3^{*}$ & $80,0^{*}$ & $2,5 \pm 0,5$ \\
\hline $\begin{array}{l}\text { Notas: CAS representa os animais companheiros dos animais saudáveis e CAD os animais companheiros dos } \\
\text { animais doentes. }{ }^{*} \text { p }<0,05 \text { representa diferença quando comparado com o grupo CAS. Os dados } \\
\text { representam média } \pm \text { erro padrão de } 5 \text { animais por grupo }\end{array}$
\end{tabular}

Figura 8 - Efeitos da convivência por 14 dias com um conspecífico portador do TAE sobre a desgranulação de mastócitos pulmonares de camundongos OVA sensibilizados e desafiados
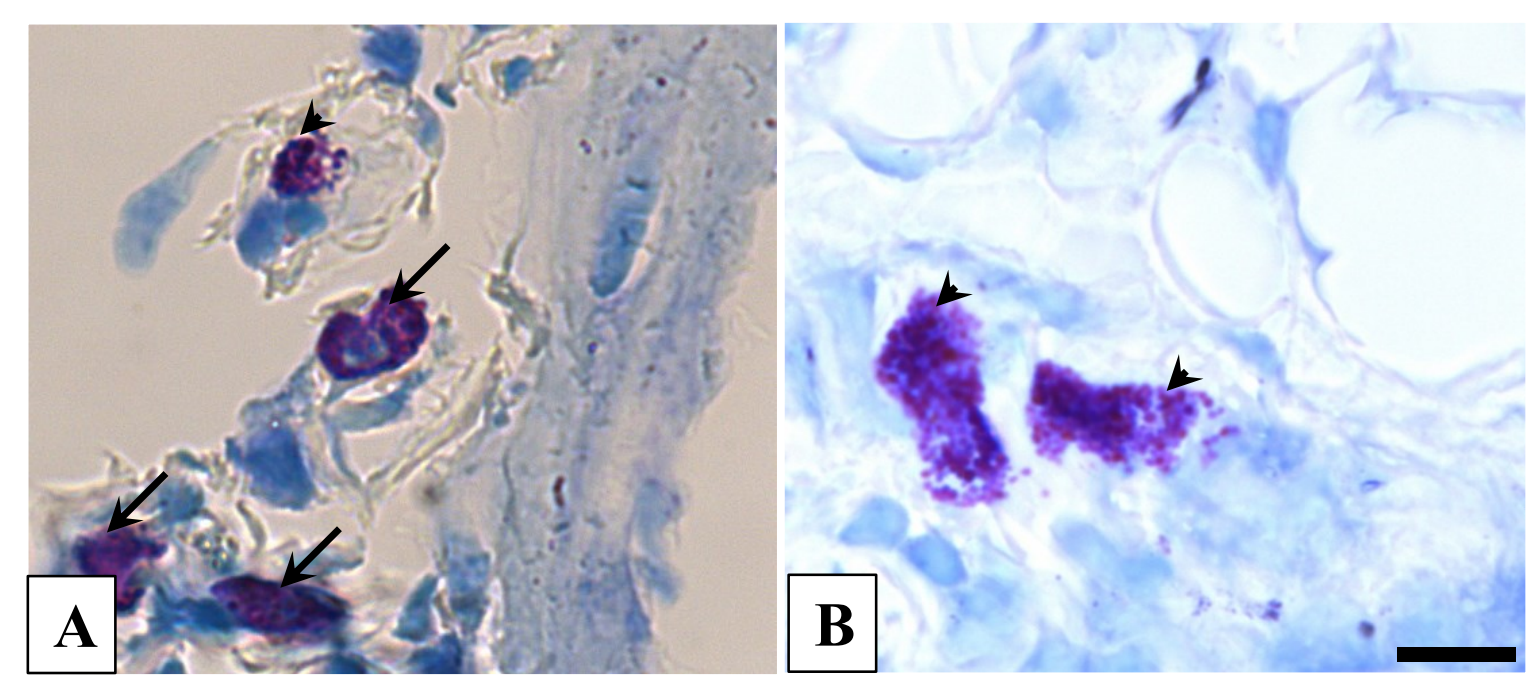

Fonte: (HAMASATO, E. K., 2015)

Notas: Análise dos mastócitos no tecido pulmonar. (A) grupo CAS, mostrando mastócitos intactos (setas) e mastócito desgranulado (cabeça de seta); (B) grupo CAD, mostrando mastócitos ativados (cabeça de seta). Coloração azul de toluidina. Barra: $5 \mu \mathrm{m}$ 


\subsection{EXPERIMENTO 7 - AVALIAÇÃO DOS EFEITOS INDUZIDOS PELA CONVIVÊNCIA POR 14 DIAS COM UM CONSPECÍFICO DOENTE SOBRE O PESO RELATIVO DE ÓRGÃOS PERIFÉRICOS (BAÇO, GLÂNDULAS ADRENAIS E TIMO)}

Foram empregados os mesmos camundongos usados no experimento 4, isto é, submetidos aos procedimentos descritos em 4.2.1 e 4.2.2; 24 horas após o último desafio com OVA, isto é, no dia $\mathrm{D}_{(14)}$, sendo deles coletados o baço, glândulas adrenais e timo para posterior análise do peso relativo de órgãos periféricos conforme descrito no item 4.2.11.

\section{Resultados}

A tabela 3 mostra os efeitos da coabitação por 14 dias com um animal portador do tumor de Ehrlich sobre o peso relativo de baço, das glândulas adrenais e do timo dos animais do grupo CAS e CAD. A análise estatística dos dados obtidos não mostrou existência de diferenças significantes $(p>0.05)$ entre os animais dos grupos CAS e CAD quanto ao peso relativo destes órgãos.

Tabela 3 - Efeitos da convivência por 14 dias com um conspecífico portador do TAE sobre o peso relativo de baço, glândulas adrenais e timo de camundongos OVA sensibilizados e desafiados

\begin{tabular}{cccc}
\hline Grupos/Tecidos & Baço & $\begin{array}{c}\text { Glândulas } \\
\text { adrenais }\end{array}$ & Timo \\
\hline CAS & $0,48 \pm 0,02$ & $0,05 \pm 0,01$ & $0,17 \pm 0,02$ \\
\hline CAD & $0,54 \pm 0,08$ & $0,04 \pm 0,01$ & $0,17 \pm 0,01$
\end{tabular}

Notas: Onde, CAS representa os companheiros dos animais saudáveis e CAD os companheiros dos animais doentes. Os dados representam média \pm erro padrão de 8 animais por grupo. 


\subsection{EXPERIMENTO 8 - AVALIAÇÃO DOS EFEITOS INDUZIDOS PELA CONVIVÊNCIA POR 3, 6, 9, 12 E 14 DIAS COM UM CONSPECÍFICO PORTADOR DO TAE SOBRE OS NÍVEIS PLASMÁTICOS DE CORTICOSTERONA}

Cinquenta camundongos foram submetidos aos mesmos procedimentos descritos em 4.2.1 e 4.2.2; os animais foram submetidos à coleta de sangue pelo plexo submandibular 3, 6 , 9, 12 e 14 dias após o início da convivência com o conspecífico doente, isto é, portador do TAE para dosagem dos níveis plasmáticos de corticosterona como descrito no item 4.2.12.

\section{Resultados}

A figura 9 ilustra os efeitos da convivência por 3, 6, 9, 12, 14 dias com um conspecífico portador do TAE sobre os níveis plasmáticos de corticosterona. A aplicação da ANOVA de duas vias mostrou existência de diferenças significantes entre os dias; contudo não foram encontradas diferenças entre os grupos CAS e CAD $\left(\mathrm{F}_{(1,4,70)}=31,42 ; \mathrm{p}>0.05\right)$ nos níveis plasmáticos deste hormônio. Especificamente, nenhuma diferença entre CAS e CAD foi encontrada ( $\mathrm{p}>0.05$ ) nos níveis plasmáticos de corticosterona nos dias $\mathrm{D}_{(3)}, \mathrm{D}_{(6)}, \mathrm{D}_{(9)}, \mathrm{D}_{(12)}$ e $\mathrm{D}_{(14)}$ de coabitação com o parceiro doente. Ressalta-se, no entanto o elevado erro padrão observado nos resultados dos grupos, fato que, seguramente, respondeu pela ausência de significâncias entre os dados dos diferentes grupos. 
Figura 9 - Efeitos da convivência por 3, 6, 9, 12 e 14 dias com um conspecífico portador do TAE sobre os níveis plasmáticos de corticosterona de camundongos OVA sensibilizados e desafiados

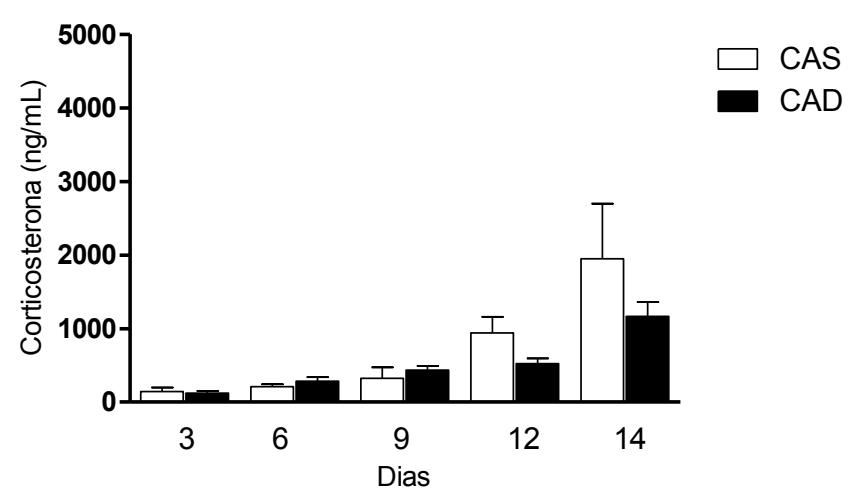

Legenda: CAS representa os animais companheiros dos animais saudáveis e CAD os animais companheiros dos animais doentes. Os dados representam média \pm erro padrão de 5 animais por grupo

\subsection{EXPERIMENTO $9-$ AVALIAÇÃO DOS EFEITOS INDUZIDOS PELA CONVIVÊNCIA POR 9 E 14 DIAS COM UM CONSPECÍFICO PORTADOR DO TAE SOBRE OS NÍVEIS PLASMÁticos DE ADRENALINA E NORADRENALINA}

Foram empregados os mesmos camundongos usados no experimento 8, isto é, submetidos aos procedimentos descritos em 4.2.1 e 4.2.2; os animais foram submetidos à coleta de sangue nos dia 9 e 14 dias após o início da convivência com um animal doente para dosagem dos níveis plasmáticos de adrenalina e noradrenalina como descrito no item 4.2.13.

\section{Resultados}

A tabela 4 mostra as concentrações plasmáticas de adrenalina e noradrenalina em camundongos dos grupos CAD e CAS, medidas nos dias de coabitação $\mathrm{D}_{(9)}$ e $\mathrm{D}_{(14)}$. Diferenças significantes entre CAD e CAS foram encontradas tanto para adrenalina como para noradrenalina. Em comparação aos animais do grupo CAS, as concentrações de adrenalina e de noradrenalina naqueles do grupo CAD foram maiores no dia $\mathrm{D}_{(9)}(\mathrm{p}<0,05)$. No entanto, e curiosamente, os níveis plasmáticos de noradrenalina foram menores $(p<0,05)$ em CAD do que em CAS no dia $\mathrm{D}_{(14)}$. Neste dia $\left(\mathrm{D}_{(14)}\right)$ não foram encontradas diferenças significantes nos níveis de adrenalina entre CAD e CAS. 
Tabela 4 - Efeitos da convivência por 9 e 14 dias com um conspecífico portador do TAE sobre os níveis plasmáticos de adrenalina e noradrenalina de camundongos OVA sensibilizados e desafiados

\begin{tabular}{ccccc}
\hline \multirow{2}{*}{$\begin{array}{c}\text { Dias de } \\
\text { coabitação }\end{array}$} & \multicolumn{2}{c}{ Adrenalina (ng/mL) } & \multicolumn{2}{c}{ Noradrenalina (ng/mL) } \\
\cline { 2 - 5 } & CAS & CAD & CAS & CAD \\
\hline $\mathbf{9}$ & $0,29 \pm 0,04$ & $0,45 \pm 0,11^{*}$ & $1,85 \pm 0,19$ & $3,98 \pm 0,69^{*}$ \\
$\mathbf{1 4}$ & $0,22 \pm 0,10$ & $0,21 \pm 0,06$ & $3,34 \pm 0,79$ & $2,29 \pm 0,54^{*}$ \\
\hline
\end{tabular}

Notas: CAS representa os animais companheiros dos animais saudáveis e CAD os animais companheiros dos animais doentes. ${ }^{*} \mathrm{p}<0,05$ representa diferença quando comparado com o grupo CAS. Os dados representam média \pm erro padrão de 5 animais por grupo

\subsection{EXPERIMENTO 10 - AVALIAÇÃO DOS EFEITOS INDUZIDOS PELA CONVIVÊNCIA POR 14 DIAS COM UM CONSPECÍFICO PORTADOR DO TAE SOBRE A ATIVIDADE GERAL NO CAMPO ABERTO}

Quarenta camundongos foram submetidos aos mesmos procedimentos descritos em 4.2.1 e 4.2.2; 24 horas após o último desafio com OVA, isto é, no dia $\mathrm{D}_{(14)}$, os animais dos diferentes grupos foram colocados individualmente no centro da arena do campo aberto para o registro da atividade geral como descrito no item 4.2.14.

\section{Resultados}

A figura 10 ilustra os efeitos da convivência por 14 dias com um conspecífico portador do TAE sobre a atividade geral dos animais dos grupos CAS e CAD no campo aberto. A análise estatística dos dados obtidos não mostrou existência de diferenças significantes $(p>0.05)$ entre os grupos CAS e CAD quanto aos parâmetros de distância percorrida $(\mathrm{cm})$, velocidade média $(\mathrm{cm} / \mathrm{s})$, porcentagem de tempo na zona central, porcentagem de tempo na zona tigmotáxica e porcentagem de tempo na zona intermediária do campo aberto. 
Figura 10 - Efeitos da convivência por 14 dias com um conspecífico portador do TAE sobre a distância percorrida (A), velocidade média (B), porcentagem de tempo na zona central (C), porcentagem de tempo na zona intermediária (D) e porcentagem de tempo na zona tigmotáxica (E) de camundongos sensibilizados e desafiados com OVA avaliados no campo aberto
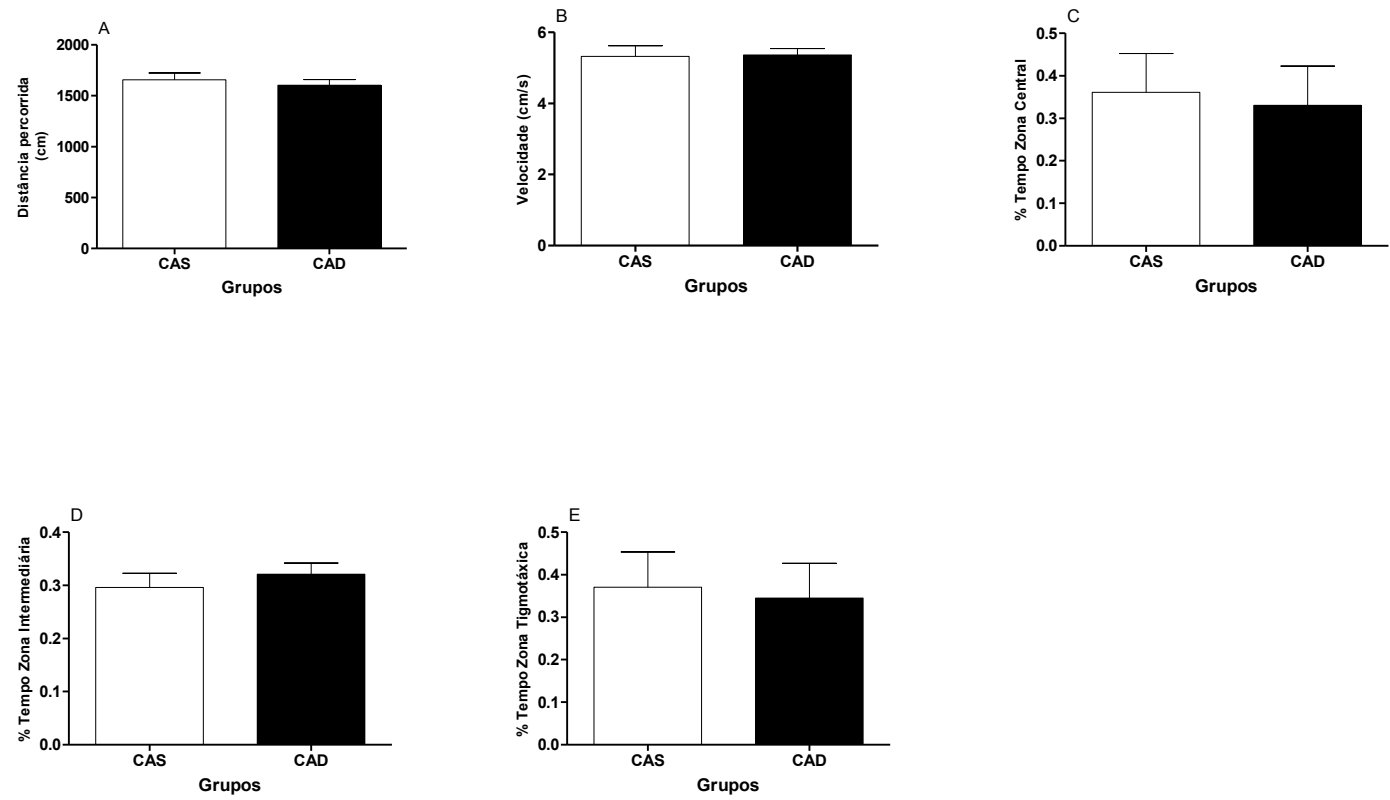

Legenda: Onde, CAS representa os animais companheiros dos animais saudáveis e CAD os animais companheiros dos animais doentes. Os dados representam média \pm erro padrão de 10 animais por grupo

\subsection{EXPERIMENTO 11 - AVALIAÇÃO DOS EFEITOS INDUZIDOS PELA CONVIVÊNCIA POR 14 DIAS COM UM CONSPECÍFICO PORTADOR DO TAE SOBRE OS NÍVEIS DE ANSIEDADE AVALIADOS NO LABIRINTO EM CRUZ ELEVADO (LCE)}

Os mesmos camundongos usados no experimento 9 foram submetido aos procedimentos descritos em 4.2.1 e 4.2.2; desta forma, 24 horas após o último desafio com OVA, isto é, no dia $\mathrm{D}_{(14)}$, os animais foram colocados individualmente no centro do labirinto em cruz elevado para o registro do comportamento como descrito no item 4.2.15. 


\section{Resultados}

A figura 11 ilustra os efeitos da convivência por 14 dias com um conspecífico portador do TAE sobre a distância percorrida $(\mathrm{cm})$, velocidade média $(\mathrm{cm} / \mathrm{s})$ e porcentagem de entradas e tempo nos braços abertos e fechados avaliados no labirinto em cruz elevado. A análise estatística dos dados obtidos mostrou existência de diferenças significantes $(p<0.05)$ entre os grupos CAS e CAD. Mais especificamente, a convivência por 14 dias com um conspecífico portador do TAE diminuiu a distância percorrida (A), a velocidade média (B), a porcentagem de entradas (C) e o tempo de permanência nos braços abertos (D) do labirinto em cruz elevado. Não observamos diferenças significantes $(p>0.05)$ na porcentagem de entradas (E) e no tempo (F) de permanência dos animais nos braços fechados do labirinto em cruz elevado.

Figura 11 - Efeitos da convivência por 14 dias com um conspecífico portador do TAE sobre a (A) distância percorrida, (B) velocidade média, (C) porcentagem de entradas e o (D) tempo de permanência nos braços abertos, (E) porcentagem de entradas e o (F) tempo de permanência nos braços fechados de camundongos OVA sensibilizados e desafiados avaliados no labirinto em cruz elevado
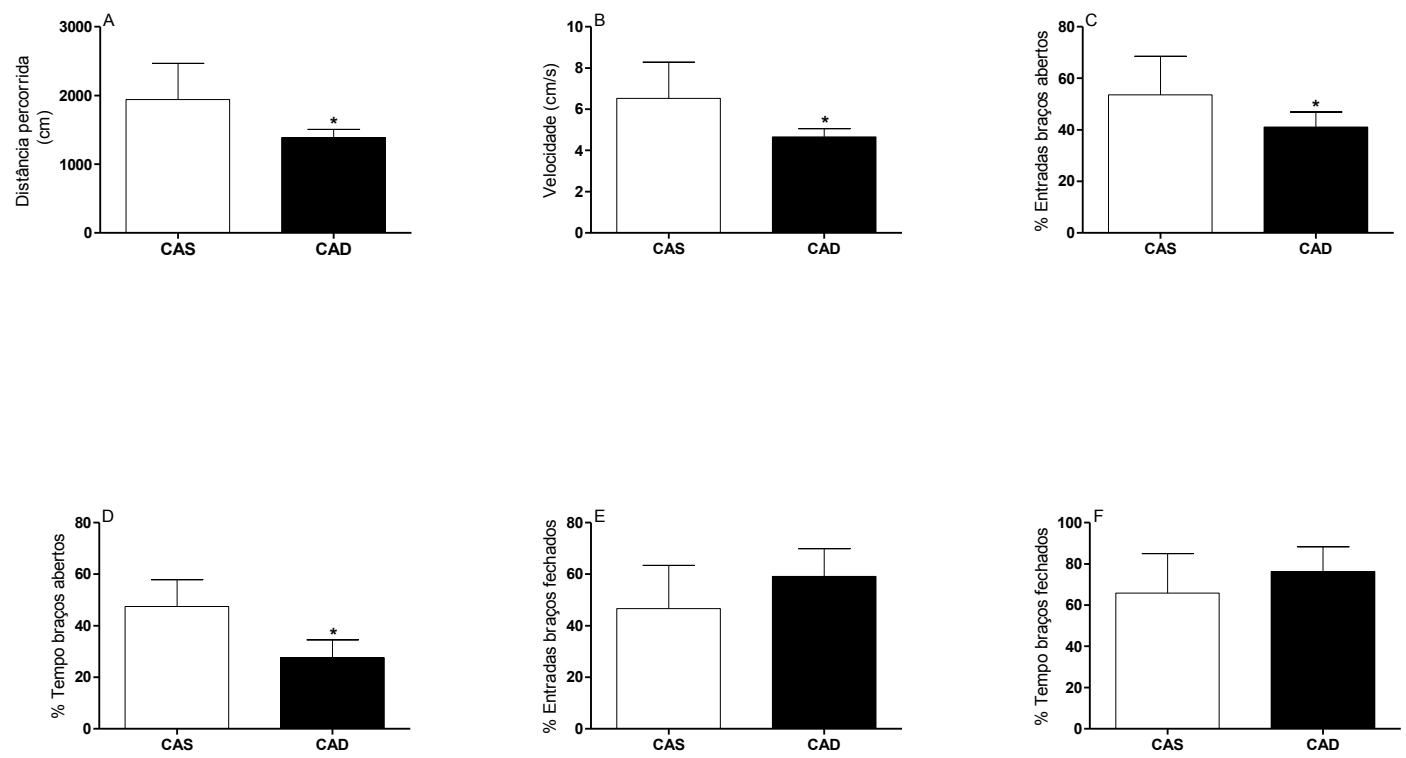

Legenda: Onde, CAS representa os animais companheiros dos animais saudáveis e CAD os animais companheiros dos animais doentes. ${ }^{*} \mathrm{p}<0,05$ representa diferença quando comparado com o grupo CAS. Os dados representam média \pm erro padrão de 10 animais por grupo 


\subsection{EXPERIMENTO 12 - AVALIAÇÃO DOS EFEITOS INDUZIDOS PELA CONVIVÊNCIA POR 14 DIAS COM UM CONSPECÍFICO PORTADOR DO TAE SOBRE A EXPRESSÃO DE CITOCINAS NO NÚCLEO PARAVENTRICULAR DO HIPOTÁLAMO, CENTRAL DA AMÍGDALA E CÓRTEX PRÉ-FRONTAL}

Trinta e dois camundongos foram submetidos aos procedimentos descritos em 4.2.1 e 4.2.2; os animais foram eutanasiados 24 horas após o último desafio com OVA, isto é, no dia $\mathrm{D}_{(14)}$, sendo deles coletado o cérebro para análise de citocinas no núcleo paraventricular do hipotálamo, central da amígdala e no córtex pré-frontal conforme descrito nos item 4.2.16.

\section{Resultados}

A figura 12 ilustra os efeitos da convivência por 14 dias com um conspecífico portador do TAE sobre a expressão de citocinas no núcleo paraventricular do hipotálamo (PVN) de camundongos OVA sensibilizados e desafiados. A análise estatística dos dados obtidos mostrou a existência de diferenças significantes $(p<0.05)$ entre os grupos CAS e CAD para a citocina IL-6. Mais especificamente, observou-se uma diminuição da expressão de IL-6 nos animais do grupo CAD em relação ao grupo CAS. Não observamos diferenças significantes ( $>$ >0.05) na expressão de C-fos e das citocinas IL-1 $\beta$, IL-4, IL-5,IL-13 e IL-33. Contudo, uma clara tendência para diminuição de IL-5 foi observada nos animais do grupo CAD nesta região em relação àqueles do grupo CAS. 
Figura 12 - Efeitos da convivência por 14 dias com um conspecífico portador do TAE sobre a expressão de Bactin (A), C-fos (B), IL-1 $\beta$ (C), IL-6 (D), IL-4 (E), IL-5 (F), IL-13 (G) ,IL-33 (H) no núcleo paraventricular do hipotálamo de camundongos OVA sensibilizados e desafiados
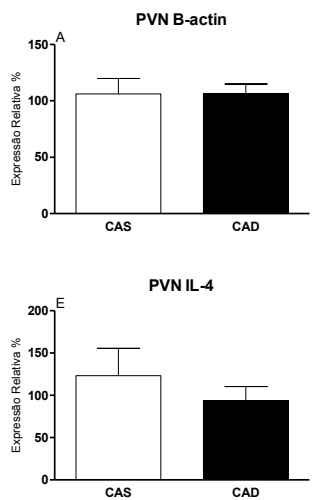
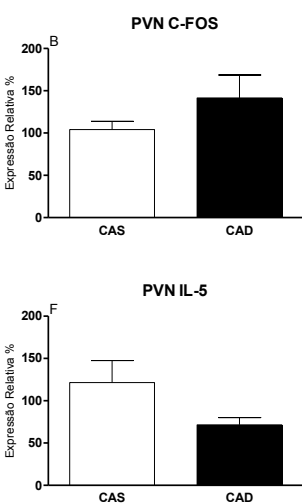
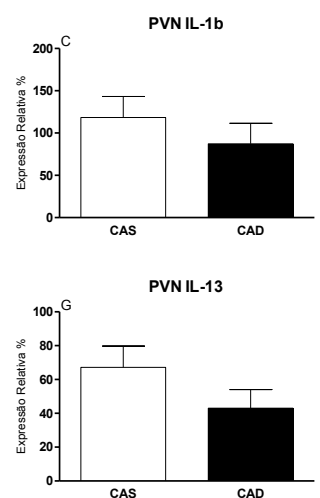
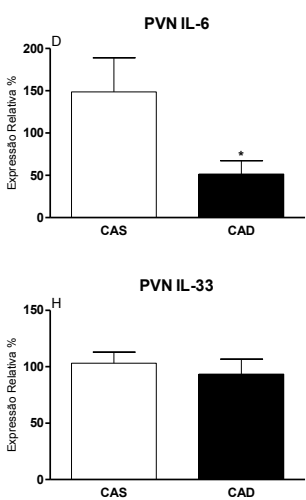

Legenda: Onde, CAS representa os animais companheiros dos animais saudáveis e CAD os animais companheiros dos animais doentes. ${ }^{*} \mathrm{p}<0,05$ representa diferença quando comparado com o grupo CAS. Os dados representam média \pm erro padrão de 8 animais por grupo.

A figura 13 ilustra os efeitos da convivência por 14 dias com um conspecífico portador do TAE sobre a expressão de citocinas no núcleo central da amígdala (CeA) de camundongos OVA sensibilizados e desafiados. Apesar de não observamos diferenças significantes ( $\mathrm{p}>0.05)$ na expressão de C-fos, IL-1 $\beta$, IL-4, IL-5, IL-6, IL-13 e IL-33 nesta região, notou-se uma clara tendência para aumento da expressão de IL-5 e diminuição de IL$1 \beta$ e IL-6 nos animais do grupo CAD em relação aos do grupo CAS.

Figura 13 - Efeitos da convivência por 14 dias com um conspecífico portador do TAE sobre a expressão de Bactin (A), C-fos (B), IL-1ß (C), IL-6 (D), IL-4 (E), IL-5 (F), IL-13 (G), IL-33 (H) no núcleo central da amígdala de camundongos OVA sensibilizados e desafiados
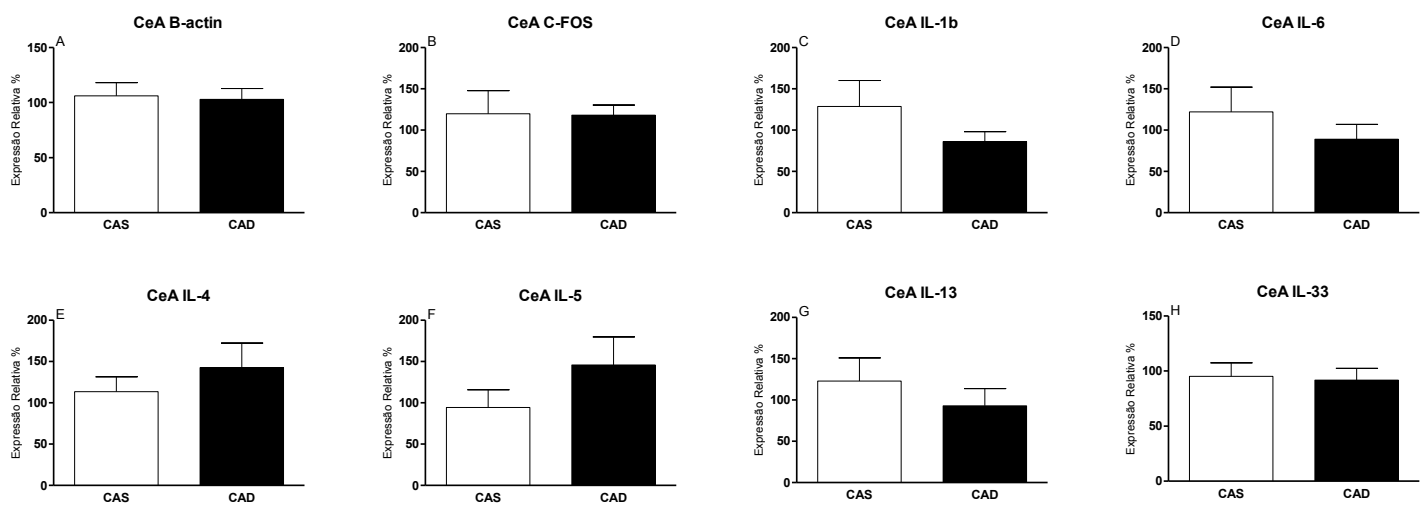

Legenda: Onde, CAS representa os animais companheiros dos animais saudáveis e CAD os animais companheiros dos animais doentes. Os dados representam média \pm erro padrão de 8 animais por grupo. 
A figura 14 ilustra os efeitos da convivência por 14 dias com um conspecífico portador do TAE sobre a expressão de citocinas no córtex pré-frontal (PFC) de camundongos OVA sensibilizados e desafiados. A análise estatística dos dados obtidos mostrou a existência de diferenças significantes $(\mathrm{p}<0.05)$ entre os animais dos grupos CAS e CAD para C-fos. Mais especificamente, observou-se uma diminuição da expressão de C-fos no grupo CAD em relação ao grupo CAS. Não observamos diferenças significantes ( $\mathrm{p}>0.05)$ na expressão das citocinas IL-1 $\beta$, IL-4, IL-5, IL-6, IL-13 e IL-33. Embora não significante, observa-se uma clara tendência para aumento da expressão de IL-4 e diminuição de IL-1 $\beta$ nos camundongos do grupo CAD.

Figura 14 - Efeitos da convivência por 14 dias com um conspecífico portador do TAE sobre a expressão de Bactin (A), C-fos (B), IL-1ß (C), IL-6 (D), IL-4 (E), IL-5 (F), IL-13 (G), IL-33 (H) no córtex préfrontal de camundongos OVA sensibilizados e desafiados
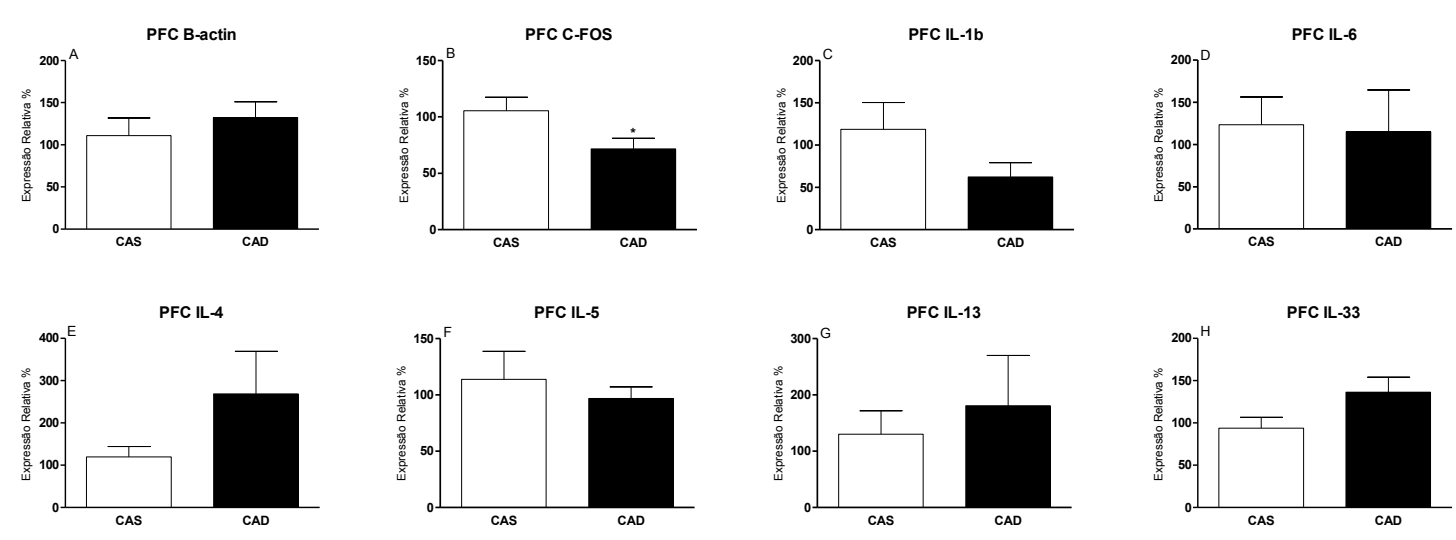

Legenda: Onde, CAS representa os animais companheiros dos animais saudáveis e CAD os animais companheiros dos animais doentes. ${ }^{*} \mathrm{p}<0,05$ representa diferença quando comparado com o grupo CAS. Os dados representam média \pm erro padrão de 8 animais por grupo. 


\section{DISCUSSÃO}

Nossos resultados mostram a influência da coabitação de camundongos OVA sensibilizados e desafiados com conspecíficos portadores do TAE; eles mostram que o estresse psicológico induzido pela coabitação durante 14 dias exacerba a resposta inflamatória alérgica pulmonar de camundongos OVA sensibilizados e desafiados. Especificamente, nossos resultados mostram: (1) aumento da migração de eosinófilos e neutrófilos para o LBA; (2) diminuição na celularidade da medula óssea (3) tendência de aumento de leucócitos no sangue periférico (4) aumento do perfil de citocinas de perfil $\mathrm{Th}_{2}$ e diminuição de citocinas perfil $\mathrm{Th}_{1}$ no sobrenadante do LBA; (5) aumento dos níveis de IgG1-OVA, diminuição do níveis de IgG2a-OVA e ausência de diferenças de IgE-OVA no soro; (6) aumento da expressão das moléculas de adesão celular ICAM-1, VCAM-1 e L-selectina em granulócitos do LBA; (7) aumento da desgranulação de mastócitos. No entanto, a coabitação com um parceiro doente (8) reduziu a capacidade de resposta in vitro da traquéia à metacolina e (9) não alterou os níveis plasmáticos de corticosterona avaliados nos dias $\mathrm{D}_{(3)}, \mathrm{D}_{(6)}, \mathrm{D}_{(9)}, \mathrm{D}_{(12)} \mathrm{e}$ $\mathrm{D}_{(14)}$ de coabitação com o parceiro doente; (10) aumentou no dia $\mathrm{D}_{(9)}$ os níveis plasmáticos de adrenalina e noradrenalina e diminuiu no dia $\mathrm{D}_{(14)}$ os níveis plasmáticos de noradrenalina. Além disso, mostram (11) aumento dos níveis de ansiedade avaliada no labirinto em cruz elevado; (12) ausência de alterações comportamentais indicativas de ansiedade no campo aberto; (13) diminuição na expressão de IL-6 no PVN e (14) diminuição na expressão de Cfos no PFC. Esses dados sugerem que a exacerbação da resposta inflamatória alérgica pulmonar observada nos animais do grupo CAD seja consequência do estresse psicológico induzido pela coabitação forçada com o animal doente por 14 dias. Neste contexto, sugerimos o envolvimento do Sistema Nervoso Autônomo Simpático (SNS) com a liberação de adrenalina e noradrenalina e uma mudança no perfil de citocinas $\mathrm{Th}_{1} / \mathrm{Th}_{2}$ para uma resposta do tipo $\mathrm{Th}_{2}$ como um dos mecanismos de recrutamento celular para as vias aéreas e consequente exacerbação da inflamação alérgica pulmonar. Esta hipótese será interpretada e discutida dentro de um contexto da Neuroimunomodulação.

Cabe prelinarmente destacar trabalhos prévios provenientes de nosso grupo de pesquisa que mostraram ser a coabitação por 11 dias de um camundongo com outro portador de tumor ascítico de Ehrlich capaz de produzir no mesmo alterações comportamentais, imunológicas e endócrinas (MORGULIS et al., 2004; ALVES et al., 2006; ALVES; 
VISMARI; PALERMO-NETO, 2007; ALVES; RIBEIRO; PALERMO-NETO, 2012). Além disso, mostramos também que estímulos olfativos provenientes do animal doente eram fundamentais para a manifestação das alterações induzidas pela convivência com camundongos portadores do tumor de Ehrlich (ALVES; RIBEIRO; PALERMO-NETO, 2012). De fato, mais recentemente Alves e Palermo Neto (2015) mostraram que os odores liberados por camundongos portadores de tumor ascítico de Ehrlich camundongos é aversivo e induz estresse psicológico em seus companheiros de gaiola (ALVES; PALERMO-NETO, 2015). Os dados do presente trabalho confirmam e ampliam o leque de mudanças neuroimunes já observadas neste modelo experimental.

O presente estudo mostra que camundongos do grupo CAD apresentam aumento do número de eosinófilos e neutrófilos colhidos no LBA e diminuição da celularidade da medula óssea em comparação com animais do grupo CAS. Além disso, observamos uma clara tendência de aumento do número de leucócitos no sangue periférico em camundongos do grupo CAD. Sabe-se, neste sentido que o número e a proporção de leucócitos presentes na medula óssea, sangue periférico e locais inflamatórios caracterizam um estado de ativação do sistema imune, ou seja, a distribuição de células imunes no organismo durante uma resposta imune/inflamatória (OTTAWAY; HUSBAND, 1994; STEFANSKI, 2000; ENGLER et al., 2004; AZPIROZ et al., 2008). Desta forma, parece possível afirmar que o estresse psicológico induzido pela convivência com um conspecífico doente foi capaz de modular o recrutamento celular para o pulmão em camundongos OVA sensibilizados e desafiados. De fato, foram encontradas diferenças entre os animais do grupo CAD e CAS na redistribuição de leucócitos a partir da medula óssea e do sangue periférico para o espaço das vias respiratórias, bem como da via aérea para o lavado broncoalveolar (LBA).

Trabalhos da literatura ressaltam ser o estresse um importante fator para o tráfego de leucócitos (DHABHAR, 2002; 2003) bem como para o aparecimento e agravamento de sintomas de inflamação alérgica pulmonar em modelos experimentais de asma (DATTI et al., 2002; FORSYTHE et al., 2004; OKUYAMA et al., 2007; QUARCOO; PAVLOVIC; JOACHIM, 2009; HAMASATO et al., 2013). Neste sentido, os resultados agora sendo discutidos não só concordam com os trabalhos de literatura e estudos anteriores de nosso grupo, mas também reforçam a idéia de que a coabitação com um conspecífico portador do TAE induz estresse psicológico (ALVES; PALERMO-NETO, 2015). 
A inflamação das vias respiratórias é uma das principais características da asma brônquica onde se observa um infiltrado celular de eosinófilos, neutrófilos e linfócitos no tecido pulmonar e consequente obstrução do espaço das vias respiratórias. Diferentes tipos de estímulos estressores têm sido discutidos como sendo capazes de alterar o equilíbrio de citocinas $\mathrm{Th}_{1} / \mathrm{Th}_{2}$ (TAUSK; ELENKOV; MOYNIHAN, 2008). O recrutamento e a migração de eosinófilos no tecido inflamado após o desafio com antígeno é controlado por citocinas, quimiocinas e mediadores inflamatórios. As respostas imunes alérgicas estão ligadas a um desequilíbrio na resposta $\mathrm{Th}_{1} / \mathrm{Th}_{2}$, com um aumento do perfil de citocinas de perfil $\mathrm{Th}_{2}$ (MARSHALL et al., 1998; NGOC et al., 2005). No decurso das doenças alérgicas, as citocinas $\mathrm{Th}_{2}$, tais como a IL- 4 e a IL -5 , o aumento da produção de IgE específica para o alérgeno induzem a migração de leucócitos, ou seja, de eosinófilos e neutrófilos para o local da inflamação por meio de moléculas de adesão, como por exemplo a L-selectina, VCAM-1 e ICAM-1 (COTRAN; MAYADAS-NORTON, 1998).

As citocinas $\mathrm{Th}_{2}$, incluindo a IL-4, IL-5 e IL-13, têm papel importante na patogênese da inflamação e hiperreatividade das vias aéreas em modelos animais de asma (FINKELMAN et al., 2010). Estas citocinas são produzidas por vários tipos celulares, tais como as células T, mastócitos, macrófagos e células epiteliais que são encontrados ou se infiltram no microambiente pulmonar. Tem sido relatado aumento da produção de IL-4, IL-5 e IL-13 em uma série de reações alérgicas, incluindo-se aqui a asma (LEWIS et al., 2009). Sabe-se ser a IL-4 necessária para a diferenciação de células $\mathrm{T}$ em células do tipo $\mathrm{Th}_{2}$, sendo este fato primordial para a mudança do isótipo IgE em células B (ROBINSON et al., 1992). A IL-5 é uma citocina que contribui para a ativação e sobrevida dos eosinófilos e seu nível é elevado na asma de origem alérgica (HOGAN; KOSKINEN; FOSTER, 1997). A IL-10, por sua vez, é uma citocina anti-inflamatória, produzida pelos linfócitos $\mathrm{Th}_{1}$ e $\mathrm{Th}_{2}$, monócitos e macrófagos; atuando na inibição da produção de citocinas por fagócitos mononucleares, células NK e linfócitos $\mathrm{Th}_{2}$. Mostrou-se que a IL-10 suprime a atividade de mastócitos e eosinófilos e que reduz a síntese de IgE (SUGITA et al., 2003; TAILOR; TAMURA; OZATO, 2006).

Neste sentido, os resutados deste trabalho mostram que em relação ao grupo CAS os camundongos do grupo CAD apresentavam níveis aumentados de IL- 4 e IL-5 e níveis diminuídos de IL-10 e IFN- $\gamma$ no sobrenadante do LBA. Um aumento da expressão das moléculas de adesão celular ICAM-1, VCAM-1 e L- selectina, também foi observado em granulócitos do LBA de camundongos do grupo CAD. Esses dados, em seu conjunto, parecem explicar o aumento do número de leucócitos observado no LBA de animais do grupo 
CAD e sugerem que o estresse psicológico induzido pela convivência com um animal portador do TAE favorece a liberação de citocinas $\mathrm{Th}_{2}$. De fato, a citocina IL-4 é essencial para dirigir a diferenciação de células $\mathrm{Th}_{0}$ naïve em células $\mathrm{Th}_{2}$ no curso de uma inflamação alérgica (RENAULD, 2001). A IL-4 foi também relatada como sendo capaz de facilitar a troca de isótipo e a produção da imunoglobulina $\mathrm{E}(\mathrm{IgE})$, uma importante característica presente em doenças alérgicas. Por outro lado, entre as funções da IL-5 destacam-se: diferenciar, ativar e aumentar a viabilidade de eosinófilos (BARNES, 2008; FINKELMAN et al., 2010). Os eosinófilos ativados são conhecidos por liberar potentes mediadores próinflamatórios, tais como os leucotrienos e a histamina (HOLGATE, 2008). As células $\mathrm{Th}_{1}$ secretam um perfil específico de citocinas, incluindo a IFN- $\gamma$ e TNF- $\alpha$, que favorecem a resposta imune celular (NGUYEN; CASALE, 2011). Em particular, o IFN- $\gamma$ foi relatado por antagonizar a atividade de citocinas $\mathrm{Th}_{2}$ (BUSSE; ROSENWASSER, 2003). Em contraste, a IL-10 é uma citocina conhecida por regular a atividade das citocinas $\mathrm{Th}_{1}$ (HAWRYLOWICZ; O'GARRA, 2005).

A análise do perfil de imunoglobulinas no plasma mostrou que os animais do grupo CAD apresentavam aumento dos níveis de IgG1-OVA e diminuição dos de IgG2a-OVA em comparação aos animais do grupo CAS. Com relação aos níveis de IgE-OVA não se observaram diferenças entre os animais dos grupos CAS e CAD, um fato que concorda com dados da literatura (CHIDA et al., 2007). De fato, tanto a IgE como a IgG1 estão ligadas ao desenvolvimento de uma resposta $\mathrm{Th}_{2}$ (NURIEVA; CHUNG, 2010). Portanto, quer nos parecer que a avaliação do perfil de imunoglobulinas juntamente com o balanço de citocinas $\mathrm{Th}_{1} / \mathrm{Th}_{2}$ sejam consistentes com a idéia de que os animais sensibilizados e desafiados com OVA que coabitaram por 14 dias com um conspecífico portador de TAE apresentam uma mudança no perfil $\mathrm{Th}_{1} / \mathrm{Th}_{2}$ para uma resposta em favor ao perfil de citocinas $\mathrm{Th}_{2}$. Além disso, e de relevância, a ausência de diferenças nos níveis de IgE-OVA observada neste trabalho parece excluir a possibilidade de que o estresse de coabitação tenha afetado a resposta de sensibilização ao antígeno.

Neste contexto, relatou-se ser a eosinofilia nas vias aéreas fator essencial para o desenvolvimento de uma inflamação alérgica (DUEZ et al., 2004). O recrutamento de eosinófilos e a subsequente ativação dessas células nas vias aéreas são reguladas principalmente pela IL-5 e IL-13, bem como pelas quimiocinas e moléculas de adesão como a eotaxina e VCAM-1 (BUSSE; LEMANSKE, 2001). De fato, sabe-se que o recrutamento de 
leucócitos a partir da medula óssea, passando pelos vasos sanguíneos e por fim chegando a um foco inflamatório é primordial para o desenvolvimento de uma resposta inflamatória sendo importante para a sequência de eventos que levam às doenças inflamatórias de origem alérgica (KELLY; HWANG; KUBES, 2007).

A migração de leucócitos para o tecido inflamado envolve interações complexas dos leucócitos com o endotélio por meio da expressão de moléculas de adesão. Para que ocorra a migração celular de leucócitos da circulação para o foco inflamatório é essencial que ocorra uma interação leucócito-endotélio mediada pelas moléculas de adesão. No presente estudo, mostramos que camundongos CAD apresentaram um aumento da expressão de ICAM-1, VCAM-1 e L- selectina em granulócitos LBA, o que pode explicar o aumento do número de eosinófilos e neutrófilos colhidas do LBA de camundongos do grupo CAD. De fato, a Lselectina atua como um receptor para que os leucócitos adentrem nos tecidos linfóides secundários via vênulas endoteliais (SCOLA et al., 2009); quanto à ICAM-1 ela é normalmente encontrada na superfície das células endoteliais, podendo sua expressão ser significativamente aumentada em decorrência da ativação endotelial por citocinas ou endotoxinas (YUSUF-MAKAGIANSAR et al., 2002). Por sua vez, mostrou-se ser a VCAM1 importante no rolamento e adesão de eosinófilos; desta forma, no endotélio de um pulmão alérgico há uma maior expressão de VCAM-1, o que implica no recrutamento de eosinófilos da circulação sanguínea para as vias aéreas. Assim, quer nos parecer que um maior número de células imunes tenham conseguido rolar e transmigrar pelo endotélio e, consequentemente, migrar e chegar ao LBA. Se verdadeira, esta hipótese justificaria o maior número de eosinófilos e neutrófilos encontrado no LBA dos animais que coabitaram por 14 dias com conspecíficos portadores do TAE.

No mesmo sentido, um estresse psicológico de disrupção social, caracterizado pela introdução de um camundongo intruso agressivo na gaiola de um camundongo residente, onde existe uma hierarquia social bem estabelecida resultou na quebra do ambiente social fato que foi correlacionado ao aumento da inflamação pulmonar via aumento da expressão no pulmão das moléculas de adesão celular ICAM-1, P-selectina e E-selectina, que localizariam e recrutariam células do sistema imune (CURRY et al., 2010). Propôs-se, assim, que o estresse psicológico de disrupção social induz a secreção de citocinas e quimiocinas próinflamatórias, aumentando assim a expressão de moléculas de adesão e o recrutamento celular para os pulmões. 
Além da migração celular para as vias aéreas, o modelo murino de asma experimental envolve, também, alterações na reatividade das vias aéreas e ativação de células residentes (células epiteliais, macrófagos e mastócitos), que secretam mediadores químicos responsáveis, entre outras funções, pela constrição das vias aéreas e pelo influxo de leucócitos para o foco inflamatório (MARTIN; FREVERT, 2005). Assim, pareceu-nos relevante avaliar também a reatividade in vitro das vias aéreas de camundongos OVA sensibilizados e desafiados após 14 dias de convivência. Nossos dados mostraram que camundongos do grupo CAD apresentam uma menor resposta in vitro da traquéia ao estímulo da metacolina.

Como relatado, observamos um maior influxo de células para o espaço broncoalveolar nos animais alérgicos do grupo CAD. Por outro lado, observamos neste mesmo grupo de animais uma menor contratilidade do músculo liso da traquéia em relação ao observado em animais alérgicos do grupo CAS. Neste sentido, e segundo a literatura, o aumento do influxo de células para o espaço broncoalveolar não necessariamente precisa coexistir com um aumento da reatividade das vias aéreas, visto que esses eventos podem ocorrer de forma dissociada (TOURNOY et al., 2000; LINO DOS SANTOS FRANCO et al., 2006). Portanto, podemos admitir que a hiporreatividade observada nos animais do grupo CAD poderia ter sido relacionada a outros fenômenos, como o balanço entre a liberação de mediadores inflamatórios que causam a broncoconstrição (leucotrienos e tromboxanos) e aqueles que causam a broncodilatação (óxido nítrico). Neste sentido, tais mediadores não são produzidos apenas pelas células inflamatórias recrutadas para o ambiente pulmonar, mas também pelo músculo liso, células epiteliais e células do sistema nervoso sensorial (SHANG et al., 2010). Assim, a hiporreatividade observada nos animais do grupo CAD pode ser entendida como um reflexo a um aumento na produção de mediadores que induzem a broncodilatação. De fato Vaniotis et al. (2013) mostraram a ativação de receptores adrenérgicos acoplados a proteína $G$ induzidos pela produção de óxido nítrico no tecido cardíaco.

O modelo murino de asma experimental envolve, também, a ativação de células residentes tais como os mastócitos, as células epiteliais e os macrófagos; que secretam mediadores químicos responsáveis, entre outras funções, pela constrição das vias aéreas e pelo influxo de leucócitos para o foco inflamatório (MARTIN; FREVERT, 2005). Uma vez que nossos resultados mostraram uma exacerbação da resposta inflamatória alérgica pulmonar em camundongos OVA sensibilizados e desafiados com um aumento no número de leucócitos no LBA de camundongos que conviveram com um conspecífico portador do TAE, pareceunos relevante avaliar também a desgranulação de mastócitos no tecido pulmonar desses 
camundongos após 14 dias de coabitação com o animal doente. Nossos dados demonstram um aumento na desgranulação de mastócitos nos camundongos do grupo CAD em relação aos animais do grupo CAS. Estes dados são coerentes com os demais resultados obtidos neste estudo, uma vez que, neste grupo de animais o maior número de mastócitos desgranulados resultou em uma maior liberação de mediadores inflamatórios, o que levaria, consequentemente, a um aumento do recrutamento celular de eosinófilos e neutrófilos para o LBA como observado nos animais do grupo CAD. Estes achados parecem ser muito importantes uma vez que a desgranulação de mastócitos é essencial para o estabelecimento da inflamação alérgica pulmonar e para a ativação fagocitária. Este resultado pode, então, explicar o aumento na migração leucocitária para os pulmões nos animais que conviveram por 14 dias com um conspecífico portador do TAE.

Os estressores físicos e psicológicos são conhecidos por induzir mudanças neuroendócrinas (MASINI et al., 2012) e imunes (ELENKOV et al., 2000; KOHM; SANDERS, 2000). É de amplo conhecimento que os glicocorticóides e as catecolaminas liberados em consequência de um estímulo estressor são potentes imunomoduladores, sendo capazes de direcionar o balanço $\mathrm{Th}_{1} / \mathrm{Th}_{2}$ para uma resposta do tipo $\mathrm{Th}_{2}$. Neste sentido, a literatura vem mostrando que o estresse psicológico induz rápida e reversível mudança na distribuição de subpopulações de leucócitos do sangue periférico, sendo a corticosterona e as catecolaminas os principais mediadores dessas mudanças (DHABHAR et al., 1996; ELENKOV et al., 2000; ZHANG et al., 2009). Segundo Dhabhar (1994), os animais estressados apresentam níveis elevados de corticosterona no plasma, acompanhados por significante diminuição no número e porcentagem de linfócitos e aumento no número e porcentagem de neutrófilos; sendo estes efeitos reduzidos em animais adrenalectomizados.

Segundo Iwakabe et al. (1998), ratos submetidos a um estresse de imobilização exibiram um aumento dos níveis séricos de corticosterona, diminuição da atividade de células NK e diminuição da produção de IFN- $\gamma$ e IL-4, o que demonstrou ser o estresse capaz de induzir uma mudança no equilíbrio de citocinas $\mathrm{Th}_{1} / \mathrm{Th}_{2}$, favorecendo uma resposta $\mathrm{Th}_{2}$. Trabalhos de nossos laboratórios conduzidos por Portela et al. (2001), mostraram que ratos submetidos ao estresse de choque nas patas apresentaram sinais comportamentais indicativos de elevados níveis de estresse avaliado por meio do teste de vocalização ultrassônica e do campo aberto e aumento do número de leucócitos no LBA em comparação com os 
sensibilizados e desafiados com OVA, mostrando uma correlação positiva entre as mudanças comportamentais observadas e o agravamento da resposta inflamatória pulmonar alérgica.

No presente estudo, e mais uma vez não foram encontradas diferenças nos níveis de corticosterona no plasma entre os animais dos grupos CAD e CAS entre os dias $\mathrm{D}_{(3)}$ e $\mathrm{D}_{(14)}$. $\mathrm{O}$ aumento dos níveis de corticosterona observado em camundongos $\mathrm{CAD}$ no dia $\mathrm{D}_{(12)}$ parece estar relacionado ao estresse imposto pelo procedimento de coleta por meio do plexo submandibular das amostras de sangue do que a própria convivência com um conspecífico doente. De fato, este efeito foi também observado nos animais CAS no dia $\mathrm{D}_{(12)}$. A ausência de alterações nos níveis de corticosterona observados no presente trabalho está de acordo com os dados anteriores relatados por nós em outros trabalhos de nossos laboratórios em camundongos fêmeas (MORGULIS et al., 2004; ALVES et al., 2010) e machos (MACHADO, 2013). Além disso, a coabitação com um conspecífico não alterou os pesos das glândulas adrenais, do baço e do timo e os níveis de corticosterona nos camundongos CAD. Isto sugere que as alterações impostas nos camundongos CAD pelo estresse psicológico de coabitação com um conspecífico doente não dependa exclusivamente da atividade do eixo HPA. Estes dados, no entanto, não excluem uma possível alteração na atividade do eixo HPA. $\mathrm{Na}$ verdade, a diminuições dos níveis de $\mathrm{ACTH}$, na presença de níveis semelhantes de corticosterona já foram relatados em ratos submissos após um estresse psicológico induzido por confronto social (LIGHTMAN et al., 2002; JAHNG, 2011). Neste sentido, não nos parece impossível sugerir que a falta de mudanças significantes nos níveis de corticosterona plasmática entre os animais dos grupos CAD e CAS possa também estar relacionada a mecanismos de feedback ocorridos no eixo HPA e induzidos pelas condições de estresse psicológico mantido por 14 dias nos animais do grupo CAD.

A ativação do SNS, em resposta ao estresse aumenta os níveis plasmáticos de catecolaminas (ELENKOV et al., 2000; KOHM; SANDERS, 2000; POWELL; TARR; SHERIDAN, 2013). Observou-se neste trabalho um aumento nos níveis plasmáticos de adrenalina e noradrenalina no dia $\mathrm{D}_{(9)}$ em camundongos $\mathrm{CAD}$ em comparação com os animais do grupo CAS, o que é consistente com os dados por nós relatados anteriormente em camundongos fêmeas (ALVES; PALERMO-NETO, 2015). Naquele trabalho, utilizando um modelo experimental semelhante ao do presente estudo, relatou-se um aumento dos níveis de catecolaminas no plasma entre os dias $\mathrm{D}_{(2)}$ e $\mathrm{D}_{(9)}$ de convivência. As catecolaminas são conhecidas por alterar a atividade de células do sistema imune por meio de efeitos em receptores beta-adrenérgicos acoplados à proteína G (KOHM; SANDERS, 2000). A este 
respeito, as catecolaminas regulam vários aspectos das respostas humorais envolvidos na inflamação alérgica pulmonar, incluindo: (1) a expressão de IL-4, IL-5 e IL-13 na sequência a exposição ao alérgeno (TORRES et al., 2005); (2) a liberação de histamina pelos mastócitos ativados (ELENKOV; CHROUSOS, 1999) e (3) o recrutamento e ativação de eosinófilos nas vias aéreas (TRUEBA; RITZ, 2013). Assim, sugerimos que a ativação do SNS e a subsequente liberação de catecolaminas com a mudança para uma resposta $\mathrm{Th}_{2}$ como um dos mecanismos de recrutamento celular para as vias aéreas e exacerbação da inflamação alérgica pulmonar observada neste trabalho nos camundongos do grupo CAD.

Entretanto, uma significante diminuição dos níveis de noradrenalina no plasma foi observada em camundongos do grupo $\mathrm{CAD}$ no dia $\mathrm{D}_{(14)}$, ou seja, depois de 14 dias de convivência com o parceiro doente. Estes dados são também consistentes com aqueles previamente relatados por nosso grupo de pesquisa (ALVES; PALERMO-NETO, 2015), eles sugerem que o SNS pode também passar por adaptações fisiológicas de homeostase em resposta ao estresse imposto pela convivência de longo prazo com os camundongos portadores do TAE.

Uma vez caracterizadas as alterações neuroimunes, pareceu-nos interessante avaliar em dois testes independentes as possíveis alterações comportamentais induzidas pela coabitação por 14 dias com um conspecífico doente sobre a atividade geral dos animais OVA sensibilizados e desafiados no campo aberto e sobre os níveis de ansiedade em um labirinto em cruz elevado. No que diz respeito ao comportamento dos animais dos grupos CAS e CAD no campo aberto os dados do presente trabalho não mostraram diferenças significantes entre os mesmos quanto à atividade locomotora, velocidade média e tempo de permanência nas áreas central, tigmotáxica e intermediária do campo aberto.

Segundo a literatura, camundongos OVA sensibilizados e desafiados não mostram diferenças na atividade locomotora no campo aberto e na contagem de bolus fecais (cujo aumento indica ansiedade) em relação aos animais de um grupo controle (TONELLI et al., 2009). Contudo, já se mostrou uma redução significante no tempo dispendido na área central do campo aberto em animais alérgicos em relação aos animais controle, um fato indicativo de aumento da ansiedade. Em camundongos alérgicos e submetidos ao estresse de disrupção social (um modelo experimental de estressor psicológico), no qual o animal foi exposto a um camundongo agressivo e intruso colocado em sua gaiola de moradia por um período de 120 minutos por 6 ciclos consecutivos, mostrou-se uma diminuição de atividade dos animais na 
área central do campo aberto juntamente com aumento da atividade ambulatorial e da contagem de bolus fecais (LI et al., 2013). Segundo os autores, os dados sugeriram um aumento dos níveis de ansiedade destes animais imposto pelo estresse de disrupção social.

Por outro lado, mostrou-se que a natação forçada (um estressor agudo e classificado como um estressor físico e ou psicológico na literatura (CULLINAN et al., 1995; NEUMANN et al., 1998; DAYAS et al., 2001; SEQUEIRA-CORDERO et al., 2014)) aplicado a camundongos alérgicos não produziu efeitos quer no tempo de natação quer no tempo de imobilidade gasto pelos animais alérgicos em relação a outros não alérgicos, mostrando este fato que a alergia per se não induz comportamento do tipo depressivo em camundongos (SUTHERLAND et al., 2009). No entanto, uma importante constatação do trabalho destes autores foi que os camundongos independentemente do estado alérgico, passaram menos tempo nadando horizontalmente e mais tempo nadando verticalmente. Esta mudança de posição de natação horizontal para vertical sugere que estes animais tenham se cansado durante o teste, ou seja, que eles não tenham tido energia suficiente para manter uma postura horizontal. O interessante deste estudo, foi a observação de que dos nove (9) camundongos resgatados para que não morresem afogados durante o teste, sete (7) eram alérgicos, sugerindo este fato que a indução da alergia pela sensibilização e desafio por OVA tenha dificultado sua capacidade respiratória dos animais, muito provavelmente em decorrênca do aumento da inflamação pulmonar; de fato, uma situação como esta resulta em redução da capacidade respiratória, aumentando a fadiga e consequentemente a probabilidade de "afogamentos" no teste de natação forçada (SUTHERLAND et al., 2009).

Os resultados comportamentais do campo aberto obtidos neste estudo, diferem dos observados anteriormente em nossos laboratórios com camundongos fêmeas no mesmo modelo de coabitação com um conspecífico portador do TAE descritos por Alves et al. (2010); neste último trabalho, mostrou-se um grande aumento da atividade locomotora nos animais do grupo CAD em todas as zonas do campo aberto. Por outro lado, eles concordam com dados provenientes de camundongos machos obtidos também em nossos laboratórios por Machado (2013), qual seja, ausência de aumento de atividade locomotora. Neste sentido, se compararmos resultados de camundongos machos (presente estudo) com os de fêmeas (ALVES et al., 2010; PALERMO-NETO; ALVES, 2014; ALVES; PALERMO-NETO, 2015), pode-se sugerir que a coabitação com um conspecífico do mesmo gênero e sexo, portador de um TAE tenha uma resposta comportamental ao efeito estressor, de natureza bastante distinta entre camundongos machos e fêmeas. $\mathrm{O}$ que para as fêmeas poderia ser 
considerado um estímulo para afastamento, em machos poderia ser um estímulo para aproximação e em último caso até mesmo para o estabelecimento de nova hierarquia social. Ou seja, seria natural de se esperar que para uma fêmea a existência de uma companheira doente seja um fator estressante maior que para os machos, uma vez que este contato representaria um risco não apenas para ela, mas para toda a sua prole e descendência, fato que não ocorreria com os machos, que simplesmente participam do ato sexual.

De fato, um dos maiores custos do comportamento social é o aumento do risco de exposição a doenças. Esta pode ser a razão para as diferenças de gênero relatadas nos efeitos comportamentais observados no teste de campo aberto induzidos pela coabitação com conspecíficos portadores do TAE. Os machos e fêmeas apresentam níveis diferentes de investimento em relação ao comportamento de acasalamento, por exemplo. Neste sentido, sugeriu-se que a aversão de fêmeas ao cruzamento com os machos doentes reduziria o risco de que venham a contrair doenças contagiosas e, potencialmente colocar em risco o investimento parental, isto é, expondo a sua prole a doenças (BARBER et al., 2001). Como alternativa, é possível que as fêmeas escolham machos saudáveis não apenas para obter 'bons genes' de resistência à doenças, mas também para evitar uma possível contaminação. Além de ter um menor investimento em relação ao acasalamento, tem sido especulado que os camundongos machos poderiam ter vantagens com a presença de um conspecífico doente da mesma espécie, como por exemplo, nas relações de dominância e subordinação. Neste sentido, foi demonstrado elegantemente por Cohn et al. (2012) que em duplas de camundongos subordinados, na presença de companheiro de gaiola dominante doente, isto é, com comportamento doentio, aparece o comportamento agressivo nos subordinados não apenas em relação ao dominante, mas também entre si, na tentativa de estabelecer uma nova hierarquia na gaiola (COHN et al., 2012). As diferenças observadas para os efeitos do LPS e IL-1 sobre o comportamento sexual de ratos machos e fêmeas são consistentes com esta hipótese (AVITSUR; COHEN; YIRMIYA, 1997; AVITSUR; YIRMIYA, 1999). Neste sentido, as diferenças de gênero relatadas para os efeitos comportamentais da coabitação com um doente, no campo aberto podem estar relacionadas com diferenças na capacidade de machos e fêmeas em detectar, processar e responder às pistas olfativas liberadas por seus conspecíficos portadores do TAE.

Em relação aos níveis de ansiedade avaliados no labirinto em cruz elevado, os animais do grupo CAD apresentaram diminuição na atividade locomotora, velocidade média, porcentagem do número de entradas e tempo de permanência nos braços abertos do labirinto 
em cruz elevado em relação ao grupo CAS. Segundo Pellow et al. (1985), define-se ansiedade como uma resposta a uma situação na qual o comportamento é influenciado por duas forças motivacionais opostas: a curiosidade natural para explorar um ambiente novo versus uma aversão por áreas abertas. Portanto, a diminuição no número de entradas e do tempo gasto na exploração dos braços abertos do labirinto em cruz elevado encontrada nos animais do grupo CAD parece indicar a presença de níveis aumentados de ansiedade nesses animais. Interessante relatar, que não observamos um aumento no número de entradas e no tempo gasto na exploração dos braços fechados do labirinto em cruz elevado.

Trabalho de Tonelli et al. (2009) mostrou uma redução na porcentagem de tempo gasto por camundongos alérgicos nos braços abertos do LCE. Nesse sentido, e de relevância, o trabalho não apontou diferenças na atividade locomotora dos animais, medida pela distância percorrida nos braços abertos e fechados do labirinto, indicando que os efeitos diferenciais observados no tempo de permanência nos braços abertos não estavam relacionados a alterações na função motora dos animais. É relevante comentar que altos níveis de estresse e ansiedade foram mostrados em ratos OVA sensibilizados, 40 minutos após um desafio com OVA por via inalatória, fato não observado em ratos apenas sensibilizados (PALERMONETO; GUIMARAES, 2000). Desta forma, os resultados do presente trabalho sugerem que a convivência com o parceiro doente pode ter aumentado os níveis de ansiedade nos animais sensibilizados e desafiados do grupo CAD em relação àqueles do grupo CAS.

Estes dados, no entanto, contrastam com outros relatados anteriormente por nosso grupo, em fêmeas. De fato, relatamos ausência de alterações nos níveis de ansiedade de camundongos fêmeas avaliados no labirinto em cruz elevado (MORGULIS et al., 2004). Estes resultados foram atribuídos pelos autores ao grande aumento da atividade locomotora observado nas camundongas do grupo CAD dentro do labirinto em cruz elevado; de fato, em situações de aumento de atividade locomotora, como por exemplo, após a administração de psicoestimulantes como anfetamina (BIALA; KRUK, 2009), o labirinto em cruz elevado deixa de discriminar o número de entradas e a porcentagem de tempo nos braços abertos e fechados do labirinto e consequentemente, avaliar os níveis de ansiedade (PELLOW et al., 1985; LISTER, 1987). Assim, é possível que a ausência de alterações na atividade locomotora de machos do grupo CAD observada nos presente estudo tenha permitido que se observassem as alterações comportamentais induzidas pela coabitação no labirinto em cruz elevado. 
Pistas olfativas desempenham um papel fundamental na modulação de reconhecimento e interações social em uma ampla variedade de mamíferos (KAVALIERS; COLWELL; CHOLERIS, 2000; KAVALIERS; CHOLERIS; PFAFF, 2005a). Os roedores em especial, utilizam sinais químicos para reconhecer e evitar conspecíficos infectados com TAE (ALVES; RIBEIRO; PALERMO-NETO, 2012; ALVES; PALERMO-NETO, 2015), parasitas (KAVALIERS; CHOLERIS; PFAFF, 2005a) e agentes patogênicos como o LPS (KAVALIERS; CHOLERIS; PFAFF, 2005b; ARAKAWA et al., 2008; ARAKAWA; CRUZ; DEAK, 2011). Mostrou-se a presença de indivíduos doentes que convivem em uma mesma gaiola provoca uma dramática e ampla resposta comportamental e fisiológica (KAVALIERS; COLWELL; CHOLERIS, 2000; ALVES; RIBEIRO; PALERMO-NETO, 2012). Assim, e como já comentado, a capacidade de reconhecer e evitar indivíduos infectados ou potencialmente infectados se torna crucial para a manutenção da espécie. De fato, e como já comentado, quando da escolha de um companheiro para acasalamento, ratas preferem odores de machos saudáveis, evitando aquele proveniente de doentes (PENN; POTTS, 1998).

Os roedores distinguem animais infectados e não infectados com base em estímulos olfativos; mais especificamente, pelo odor exalado pelo doente. Assim, por exemplo, mostrou-se que eles têm aversão aos odores provenientes da urina de indivíduos infectados (ARAKAWA et al., 2008; TAKAHASHI, 2014). Uma resposta de aversão similar foi relatada para os odores liberados por ratos injetados com LPS (ARAKAWA; ARAKAWA; DEAK, 2009; ARAKAWA; CRUZ; DEAK, 2011) e para aqueles provenientes de camundongas injetadas com o TAE (ALVES et al., 2010; ALVES; PALERMO-NETO, 2015). Neste sentido, sabe-se que o tumor ascítico de Ehrlich e os tumores em geral produzem e liberam compostos orgânicos voláteis que são liberados no ar pelo suor, urina e/ou pela respiração (KWAK et al., 2009; MATSUMURA et al., 2010). Recentemente, postulou-se que a ligação neuroimune entre as mudanças observadas em conspecíficos de camundongos portadores de TAE envolveria o estresse psicológico gerado pela coabitação com o parceiro doente, via ativação de vias catecolaminérgicas no SNC e no SNS (HAMASATO et al., 2014; ALVES; PALERMO-NETO, 2015).

Dimorfismo sexual tem sido relatado em diversos contextos como, por exemplo: (a) em genes que codificam os neuropeptídeos envolvidos no reconhecimento e prevenção a odores de indivíduos infectados (KAVALIERS; CHOLERIS; PFAFF, 2005a); (b) no sistema do locus coeruleus de excitação durante o estresse (VALENTINO et al., 2012); (c) nos efeitos da IL-1 e do LPS no comportamento sexual (AVITSUR; YIRMIYA, 1999; ARAKAWA; 
CRUZ; DEAK, 2012); (d) no sistema vomeronasal, uma rede neural complexa envolvida no controle do comportamento de roedores (GUILLAMÓN; SEGOVIA, 1997); e (e) em algumas estruturas cerebrais que recebem a entrada em estímulos originados na região vomeronasal, tais como a área pré-óptica mediana, o núcleo hipotalâmico ventromedial e o núcleo amigdalóide medial (GUILLAMÓN; SEGOVIA, 1997). Estas são importantes áreas do SNC ativadas durante o estresse e/ou ansiedade (VALENTINO; VAN BOCKSTAELE, 2008; VALENTINO et al., 2012).

Portanto, sugerimos que a ameaça representada pelos animais portadores de TAE pode ser interpretada de forma diferente em camundongos machos e fêmeas, pelo menos em termos das repercussões na esfera comportamental. Se verdadeira, esta hipótese estaria indicando a presença de dimorfismo sexual para os efeitos comportamentais, mas não para os imunes desencadeados pela convivência com o parceiro doente. De fato, tanto camundongos machos como fêmeas apresentaram importantes alterações na esfera imune (ALVES; RIBEIRO; PALERMO-NETO, 2012; HAMASATO et al., 2014; PALERMO-NETO; ALVES, 2014).

Neste sentido, parece-nos importante relatar que existem dois sistemas olfativos que são morfologicamente e funcionalmente distintos em espécies de vertebrados: o sistema olfativo principal e o sistema olfativo acessório ou vomeronasal (GUILLAMÓN; SEGOVIA, 1997). Mostrou-se ser o sistema vomeronasal uma estrutura que apresenta dimorfismo sexual e cujo desenvolvimento é influenciado pelos hormônios gonadais presentes logo após o nascimento (GUILLAMÓN; SEGOVIA, 1997). Sabe-se que os estímulos aferentes provenientes do sistema vomeronasal são relevantes para as resposta comportamentais que se caracterizam pela presença de dimorfismo sexual (GUILLAMÓN; SEGOVIA, 1997). Embora os dados obtidos até o momento em nossos laboratórios não permitam uma análise mais aprofundada, parece-nos possível sugerir que as diferenças de gênero relatadas neste trabalho para as alterações comportamentais diferenciais entre camundongos machos e fêmeas, também relatadas em outros locais (ALVES; RIBEIRO; PALERMO-NETO, 2012; (HAMASATO et al., 2014) possam estar relacionadas a uma diferença nas capacidade de camundongos machos e fêmeas de detectar e/ou responder às pistas de odores liberados por seus conspecíficos doentes, isto é, portadores do TAE. Interessante relatar uma importante diferença neuroanatômica entre machos e fêmeas: o sistema de excitação proveniente do locus coeruleus em fêmeas que tem sido descrito como mais responsivo no processamento de informações destinadas ao lobo límbico que em machos (VALENTINO; VAN BOCKSTAELE, 2008; VALENTINO et al., 2012). Neste sentido, futuros experimentos que 
visem analisar comparativamente os efeitos comportamentais decorrentes da coabitação com animais portadores do TAE em camundongos machos e fêmeas, poderão trazer informações adicionais.

Estudos em roedores e humanos sugerem que exista uma relação direta entre a exposição a antígenos e alterações na função do SNC que poderiam justificar o aumento de ansiedade agora discutido nos animais do grupo CAD. Tanto o desafio por nebulização como aquele feito por via intranasal com OVA em camundongos sensibilizados fez com que estes evitassem passar ao lado da caixa de esquiva associado ao alérgeno; esta mesma situação, aumentou a atividade neuronal por meio da avaliação de C-fos em regiões límbicas, como no núcleo central da amígdala e no núcleo paraventricular do hipotálamo (COSTA-PINTO et al., 2005; COSTA-PINTO et al., 2006; COSTA-PINTO; BASSO; RUSSO, 2007). Como já comentado, observou-se um aumento de ansiedade avaliada pelos testes de campo aberto e labirinto em cruz elevado após nebulização de OVA em ratos OVA sensibilizados, um modelo de inflamação alérgica pulmonar (PALERMO-NETO; GUIMARÃES, 2000). No mesmo sentido, mostrou-se um aumento de ansiedade no campo aberto e ativação do núcleo paraventricular do hipotálamo e do núcleo central da amígdala no modelo de alergia alimentar em camundongos (BASSO et al., 2003; BASSO et al., 2004). Em humanos, um aumento da atividade do córtex pré-frontal foi observada por meio de ressonância magnética funcional durante a fase tardia da asma em pacientes asmáticos (ROSENKRANZ et al., 2005). Tomados em seu conjunto, estes estudos, fornecem uma base para a identificação de algumas regiões do SNC ligadas às respostas comportamentais associadas com o desafio à OVA em animais OVA sensibilizados, e reforçam a noção de que as alergias podem iniciar, perpetuar e agravar a ansiedade e vice-versa.

Neste sentido, no presente estudo, avaliamos a expressão de citocinas $\mathrm{Th}_{2}$ (IL-4, IL-5 e IL-13); pró-inflamatórias (IL-1 $\beta$ e IL-6) e IL-33 no núcleo paraventricular do hipotálamo (PVN), no núcleo central da amígdala (CeA) e no córtex pré-frontal (PFC), dos camundongos CAD e CAS, regiões estas que contêm estruturas que, como já discutido, se mostraram especialmente responsivas em modelos de alergias induzidas experimentalmente (BASSO et al., 2003; ROSENKRANZ et al., 2005; COSTA-PINTO et al., 2006).

Observamos uma diminuição significante do mRNA para IL-6 no PVN e de C-fos no PFC em animais do grupo CAD em relação a CAS no dia $\mathrm{D}_{(14)}$. Estes resultados são contrários aos relatados em outro trabalho, durante uma situação de estresse (ROHLEDER; 
ARINGER; BOENTERT, 2012). Quer nos parecer que a discrepância de dados devam-se aos diferentes protocolos experimentais usados, de fato em nosso contexto empregamos animais OVA sensibilizados e/ou OVA desafiados. Especificamente, a sensibilização e desafio com OVA per se, poderiam ter aumentado a expressão de citocinas chegando a seus níveis máximos, de forma tal que os efeitos do estresse de coabitação estaria sendo mascarado. Trabalho de Tonelli et al. (2009) mostra que camundongos alérgicos apresentam um aumento na expressão de citocinas IL-4 e IL-5 no bulbo olfatório e no PFC em relação a animais de um grupo controle. Alternativamente, a avaliação de citocinas no presente estudo foi feita no dia $\mathrm{D}_{(14)}$ de coabitação e, desta forma poderia refletir algum tipo de recuperação ou adaptação orgânica na expressão de citocinas no SNC em função do prolongado estresse imposto pela coabitação com o conspecífico doente. Este fato, já discutido anteriormente para a ativação do eixo HPA poderia justificar a diminuição na expressão de IL-6 no PVN e de C-fos no PFC.

Neste sentido, as citocinas secretadas tanto pelas células imunes como não imunes podem afetar a neurotransmissão em circuitos cerebrais relacionados com a regulação da expressão de emoções, podem também produzir mudanças hormonais semelhantes àquelas observados após a exposição ao estresse. Relevante comentar que citocinas pró-inflamatórias, incluindo a IL1- $\beta$, IL-6 e TNF- $\alpha$ já foram implicadas na etiologia de desordens de ansiedade e depressão (GADEK-MICHALSKA et al., 2013).

Curiosamente, utilizando o mesmo protocolo experimental do presente estudo, Machado (2013) mostraram que a coabitação com um conspecífico por 11 dias também não alterou a expressão das citocinas pró-inflamatórias, IL-1 $\beta$, IL-6 e TNF- $\gamma$ no hipotálamo e córtex pré-frontal avaliados por RT-PCR, o que sugere uma possível adaptação do organismo ao estresse imposto. Por outro lado, observaram que esplenócitos colhidos de camundongos submetidos ao estresse de coabitação com um parceiro doente e cultivados in vitro produziram mais IL-6, TNF- $\alpha$ e INF- $\gamma$ quando estimulados com LPS, suportando a existência de um ambiente imune pró-inflamatório induzido pelo estresse de coabitação com o conspecífico doente.

Tomados em seu conjunto, os resultados deste estudo, sugerem que o estresse psicológico gerado pela coabitação com um conspecífico doente não modificou a expressão de citocinas pró-inflamatórias no SNC, mas o fez na periferia do organismo, isto é, no ambiente pulmonar onde produziu um aumento de IL-4 e IL-5 e no baço onde aumentou os níveis de IL-6, TNF- $\alpha$ e INF- $\gamma$ (MACHADO, 2013). 
Neste sentido, as áreas límbicas avaliadas, incluindo o PVN, CeA e PFC exibem uma rápida e larga ativação no turnover de noradrenalina em resposta a estressores (TANAKA et al., 1982; IIMORI et al., 1982). Sabban e Kvetnansky (2001) relataram uma diminuição nos níveis plasmáticos de noradrenalina e adrenalina no SNC de ratos cronicamente estressados, sugerindo a possível ocorrência de uma adaptação homeostática. Neste sentido estímulos estressores foram relatados como sendo capazes de alterar de forma diferencial os fatores de transcrição relacionados com as enzimas de síntese das catecolaminas, tais como a tirosina hidroxilase e a pheniletanoamina-metiltransferase, em áreas específicas do SNC (SABBAN; KVETNANSKY, 2001). Nossos dados mostram que os camundongos do grupo CAD apresentaram uma diminuição nos níveis de noradrenalina no dia $\mathrm{D}_{(14)}$ em relação aos do grupo CAS.

Os dados gerados no presente estudo fornecem evidências experimentais de que o estresse psicológico de coabitação de 14 dias com um parceiro portador de um tumor ascítico de Ehrlich exacerbe a resposta inflamatória alérgica pulmonar em camundongos OVA sensibilizados e desafiados. Neste contexto, sugerimos o envolvimento do Sistema Nervoso Autônomo Simpático via liberação de adrenalina e de noradrenalina e consequente mudança do perfil de citocinas $\mathrm{Th}_{1} / \mathrm{Th}_{2}$ para uma resposta do tipo $\mathrm{Th}_{2}$ como diretamente envolvidos no recrutamento celular para as vias aéreas, com consequente exacerbação da resposta alérgica pulmonar.

Finalmente, e ainda no contexto da presente discussão, parece pertinente comentar dados preliminares (Anexo B), obtidos em um experimento agudo que estamos realizando; neste estudo, analisamos o perfil neuroimune de ratos que coabitaram por 15 horas com um conspecífico injetado com LPS $(500 \mu \mathrm{g} / \mathrm{Kg})$, uma endotoxina que nesta dose induz comportamento doentio. Os dados até agora obtidos (Fig. 1B) mostram que os animais do grupo CAD (que conviveram com o companheiro injetado com LPS) quando avaliados em um teste de interação social com um parceiro naïve, mostraram um aumento na frequência de escores indicativos de contato social, tais como passar sob e sobre o parceiro, perseguir o parceiro e comportamento de brincar. Estes dados sugerem que os animais do grupo CAD durante o período de coabitação com o conspecífico doente devem ter experimentado algum tipo de privação social, provavelmente em função de estar o companheiro de gaiola "doente" ou com "comportamento doentio", isto é, impossibilitado de responder a estímulos de interação social. Importante ressaltar que os animais injetados com LPS apresentaram sinais indicativos do comportamento doentio detectado pela significante diminuição da: (a) 
frequência de contato social com um novo parceiro (Fig. 1B); (b) frequência de cruzamentos em direção ao novo parceiro (Fig. 1C) e (c) atividade locomotora avaliada pela frequência de cruzamentos na caixa de avaliação comportamental (Fig. 1E). Curiosamente, os dados (Figura 2) mais uma vez, mostram que a coabitação aguda com o conspecífico injetado com LPS não alterou os níveis de corticosterona plasmáticos dos grupos CSP em relação aos do grupo CHP (que conviveram com parceiro que não foi tratado com LPS) até mesmo após um desafio por estresse de contenção. Por outro lado, e de relevância, quando desafiados após o período de coabitação com uma menor dose de LPS $(25 \mu \mathrm{g} / \mathrm{Kg})$ os animais do grupo CAD apresentaram um aumento significante na expressão de citocinas pró-inflamatórias IL-1 $\beta$, IL-6, TNF- $\alpha$ e I $\mathrm{B} \alpha$ no bulbo olfatório, núcleo central da amígdala e núcleo paraventricular do hipotálamo em relação aos do grupo CAS (Figura 3). Quer nos parecer, desta forma e ainda que preliminarmente, que a coabitação aguda com um conspecífico injetado com LPS também produza mudanças comportamentais e neuroendócrinas semelhantes àquelas relatadas para a coabitação com um conspecífico portador de TAE. 


\section{CONCLUSÕES}

\subsection{CONCLUSÕES ESPECÍFICAS}

Concluímos que o estresse psicológico induzido pela coabitação com um conspecífico portador do tumor ascítico de Ehrlich por 14 dias exacerba a resposta inflamatória alérgica pulmonar de camundongos OVA sensibilizados e desafiados avaliados pelo:

$\checkmark$ Aumento do número de leucócitos totais bem como o número de eosinófilos e neutrófilos no LBA;

$\checkmark$ Aumento de citocinas perfil $\mathrm{Th}_{2}$ e diminuição de citocinas perfil $\mathrm{Th}_{1}$ no sobrenadante do LBA;

$\checkmark$ Aumento dos níveis plasmáticos de IgG1-OVA e diminuição dos níveis de IgG2aOVA;

$\checkmark$ Aumento da expressão das moléculas de adesão celular ICAM-1, VCAM-1 e Lselectina em granulócitos do LBA;

$\checkmark$ Aumento da desgranulação de mastócitos pulmonares;

$\checkmark$ Redução na capacidade de resposta in vitro da traquéia à metacolina.

Observamos, ainda e de relevância que a coabitação com um conspecífico portador do tumor ascítico de Ehrlich por 14 dias em camundongos OVA sensibilizados e desafiados:

$\checkmark$ Não alterou os níveis de corticosterona plasmáticos nos dias $\mathrm{D}_{(3)}, \mathrm{D}_{(6)}, \mathrm{D}_{(9)} \mathrm{D}_{(12)}$ e $\mathrm{D}_{(14)}$ de coabitação ; 
$\checkmark$ Aumentou os níveis plasmáticos de adrenalina e noradrenalina no dia $\mathrm{D}_{(9)}$ de coabitação;

$\checkmark$ Diminuiu os níveis plasmáticos de noradrenalina no dia $\mathrm{D}_{(14)}$ de coabitação;

$\checkmark$ Aumentou os níveis de ansiedade avaliada no labirinto em cruz elevado mas não no campo aberto;

$\checkmark$ Diminuiu a expressão de IL-6 no núcleo paraventricular do hipotálamo e C-fos no córtex pré-frontal.

\subsection{CONCLUSÕES GERAIS}

Concluímos, que o estresse psicológico de coabitação com um conspecífico portador do tumor ascítico de Ehrlich exacerba a resposta inflamatória alérgica pulmonar de camundongos OVA sensibilizados e desafiados. Tomados em seu conjunto, quer nos parecer que a coabitação prolongada de 14 dias com o conspecífico injetado com o TAE ative o Sistema Nervoso Autônomo Simpático com a subsequente liberação de adrenalina e noradrenalina que, por sua vez modificaria o perfil de citocinas $\mathrm{Th}_{1} / \mathrm{Th}_{2}$ em favor do tipo $\mathrm{Th} 2$, sendo estes os prováveis mecanismos que resultariam no maior recrutamento celular agora observado nas vias aéreas dos animais do grupo CAD em relação a CAS. 


\section{REFERÊNCIAS}

ADER, R.; COHEN, N.; FELTEN, D. Psychoneuroimmunology: interactions between the nervous system and the immune system. Lancet, v. 345, n. 8942, p. 99-103, 1995.

AHMED, H.; CHATTERJEE, B. P.; DEBNATH, A. K. Interaction and in vivo growth inhibition of Ehrlich ascites tumor cells by jacalin. Journal of Biosciences, v. 13, n. 4, p. 419-424, 1988.

ALVES, G. J.; VISMARI, L.; FLORIO, J. C.; PALERMO-NETO, J. Cohabitation with a sick cage mate: Effects on noradrenaline turnover and neutrophil activity. Neuroscience

Research, v. 56, n. 2, p. 172-179, 2006.

ALVES, G. J.; VISMARI, L.; PALERMO-NETO, J. Cohabitation with a sick cage mate: effects on ascitic form of Ehrlich tumor growth and macrophage activity.

Neuroimmunomodulation, v. 14, n. 6, p. 297-303, 2007.

ALVES, G. J.; VISMARI, L.; LAZZARINI, R.; MERUSSE, J. L.; PALERMO-NETO, J. Odor cues from tumor-bearing mice induces neuroimmune changes. Behavioural Brain Research, v. 214, n. 2, p. 357-367, 2010.

ALVES, G. J.; RIBEIRO, A.; PALERMO-NETO, J. The neuroimmune changes induced by cohabitation with an Ehrlich tumor-bearing cage mate rely on olfactory information. Brain, Behavior, and Immunity, v. 26, n. 1, p. 32-39, 2012.

ALVES, G. J.; PALERMO-NETO, J. Odor Cues Released by Ehrlich Tumor-Bearing Mice Are Aversive and Induce Psychological Stress. Neuroimmunomodulation, v.22, n.3, p.1219, 2015.

ARAKAWA, H.; BLANCHARD, D. C.; ARAKAWA, K.; DUNLAP, C.; BLANCHARD, R. $\mathrm{J}$. Scent marking behavior as an odorant communication in mice. Neuroscience \&

Biobehavioral Reviews, v. 32, n. 7, p. 1236-1248, 2008.

ARAKAWA, H.; ARAKAWA, K.; DEAK, T. Acute illness induces the release of aversive odor cues from adult, but not prepubertal, male rats and suppresses social investigation by conspecifics. Behavioral Neuroscience, v. 123, n. 5, p. 964-978, 2009.

ARAKAWA, H.; CRUZ, S.; DEAK, T. From models to mechanisms: Odorant communication as a key determinant of social behavior in rodents during illness-associated states. Neuroscience \& Biobehavioral Reviews, v. 35, n. 9, p. 1916-1928, 2011. 
ARAKAWA, H.; CRUZ, S.; DEAK, T. Attractiveness of illness-associated odorant cues in female rats is modulated by ovarian hormones, but not associated with pro-inflammatory cytokine levels. Brain, Behavior, and Immunity, v. 26, n. 1, p. 40-49, 2012.

AVITSUR, R.; COHEN, E.; YIRMIYA, R. Effects of Interleukin-1 on Sexual Attractivity in a Model of Sickness Behavior. Physiology \& Behavior, v. 63, n. 1, p. 25-30, 1997.

AVITSUR, R.; YIRMIYA, R. The Immunobiology of Sexual Behavior: Gender Differences in the Suppression of Sexual Activity During Illness. Pharmacology Biochemistry and Behavior, v. 64, n. 4, p. 787-796, 1999.

AZPIROZ, A.; DE MIGUEL, Z.; FANO, E.; VEGAS, O. Relations between different coping strategies for social stress, tumor development and neuroendocrine and immune activity in male mice. Brain, Behavior, and Immunity, v. 22, n. 5, p. 690-698, 2008.

BAILEY, M. T. Stress, asthma, and infection: putting the pieces together. Brain, Behavior, and Immunity, v. 29, p. 9-10, 2013.

BALAMURUGAN, E.; REDDY, B.; MENON, V. Antitumor and antioxidant role of Chrysaora quinquecirrha (sea nettle) nematocyst venom peptide against ehrlich ascites carcinoma in Swiss Albino mice. Molecular and Cellular Biochemistry, v. 338, n. 1-2, p. 69-76, 2010.

BARBER, I.; ARNOTT, S. A.; BRAITHWAITE, V. A.; ANDREW, J.; HUNTINGFORD, F. A. Indirect fitness consequences of mate choice in sticklebacks: offspring of brighter males grow slowly but resist parasitic infections. Proceedings. Biological Sciences / The Royal Society, v. 268, n. 1462, p. 71-76, 2001.

BARNES, P. J. Molecular mechanisms of glucocorticoid action in asthma. Pulmonary Pharmacology Therapeutics, v. 10, n. 1, p. 3-19, 1997.

BARNES, P. J. Immunology of asthma and chronic obstructive pulmonary disease. Nature Reviews. Immunology, v. 8, n. 3, p. 183-192, 2008.

BARTROP, R. W.; LUCKHURST, E.; LAZARUS, L.; KILOH, L. G.; PENNY, R. Depressed lymphocyte function after bereavement. Lancet, v. 1, n. 8016, p. 834-836, 1977.

BASSO, A.; COSTA-PINTO, F.; BRITTO, L.; DE SÁ-ROCHA, L.; PALERMO-NETO, J. Neural pathways involved in food allergy signaling in the mouse brain: role of capsaicinsensitive afferents. Brain Research, v. 1009, n. 1-2, p. 181-188, 2004. 
BASSO, A. S.; DE SA-ROCHA, L. C.; PALERMO-NETO, J. Immune-induced flavor aversion in mice: modification by neonatal capsaicin treatment. Neuroimmunomodulation, v. 9, n. 2, p. 88-94, 2001.

BASSO, A. S.; PINTO, F. A.; RUSSO, M.; BRITTO, L. R.; DE SA-ROCHA, L. C.; PALERMO NETO, J. Neural correlates of IgE-mediated food allergy. Journal of Neuroimmunology, v. 140, n. 1-2, p. 69-77, 2003.

BESEDOVSKY; DEL REY, A. Immune-neuro-endocrine interactions: facts and hypotheses. Endocrine Reviews, v. 17, n. 1, p. 64-102, 1996.

BIALA, G.; KRUK, M. Effects of co-administration of bupropion and nicotine or damphetamine on the elevated plus maze test in mice. Journal of Pharmacy and Pharmacology, v. 61, n. 4, p. 493-502, 2009.

BICE, D.; SEAGRAVE, J.; GREEN, F. Animal models of asthma: potential usefulness for studying health effects of inhaled particles. Inhalation Toxicology, v. 12, n. 9, p. 829-862, 2000 .

BLALOCK, J. E. The immune system as a sensory organ. Journal of Immunology, v. 132, n. 3, p. 1067-1070, 1984.

BLANCHARD, R. J.; MCKITTRICK, C. R.; BLANCHARD, D. C. Animal models of social stress: effects on behavior and brain neurochemical systems. Physiology \& Behavior, v. 73, n. 3, p. 261-271, 2001.

BLANCHET, M. R.; MCNAGNY, K. M. Stem cells, inflammation and allergy. Allergy, Asthma, and Clinical Immunology, v. 5, n. 1, p. 13, 2009.

BUSSE, W. W.; LEMANSKE, R. F., JR. Asthma. The New England Journal of Medicine, v. 344, n. 5, p. 350-362, 2001.

BUSSE, W. W.; ROSENWASSER, L. J. Mechanisms of asthma. The Journal of Allergy and Clinical Immunology, v. 111, n. 3, p. S799-S804, 2003.

CHIDA, Y.; SUDO, N.; SONODA, J.; HIRAMOTO, T.; KUBO, C. Early-Life Psychological Stress Exacerbates Adult Mouse Asthma via the Hypothalamus-Pituitary-Adrenal Axis. American Journal of Respiratory and Critical Care Medicine, v. 175, n. 4, p. 316-322, 2007. 
COHN, D. W. H.; GABANYI, I.; KINOSHITA, D.; DE SÁ-ROCHA, L. C.

Lipopolysaccharide administration in the dominant mouse destabilizes social hierarchy.

Behavioural Processes, v. 91, n. 1, p. 54-60, 2012.

CONNOR, T. Methylenedioxymethamphetamine (MDMA, 'Ecstasy'): a stressor on the immune system. Immunology, v. 111, n. 4, p. 357-367, 2004.

COSTA-PINTO, F.; BASSO, A.; RUSSO, M. Role of mast cell degranulation in the neural correlates of the immediate allergic reaction in a murine model of asthma. Brain, Behavior, and Immunity, v. 21, n. 6, p. 783-790, 2007.

COSTA-PINTO, F. A.; BASSO, A. S.; BRITTO, L. R.; MALUCELLI, B. E.; RUSSO, M. Avoidance behavior and neural correlates of allergen exposure in a murine model of asthma. Brain, Behavior, and Immunity, v. 19, n. 1, p. 52-60, 2005.

COSTA-PINTO, F. A.; BASSO, A. S.; DE SA-ROCHA, L. C.; BRITTO, L. R.; RUSSO, M.; PALERMO-NETO, J. Neural correlates of IgE-mediated allergy. Annals of the New York Academy of Sciences, v. 1088, p. 116-131, 2006.

COTRAN, R. S.; MAYADAS-NORTON, T. Endothelial adhesion molecules in health and disease. Pathologie-Biologie, v. 46, n. 3, p. 164-170, 1998.

CULlinAN, W. E.; HERMAN, J. P.; BATTAGLIA, D. F.; AKIL, H.; WATSON, S. J. Pattern and time course of immediate early gene expression in rat brain following acute stress. Neuroscience, v. 64, n. 2, p. 477-505, 1995.

CURRY, J. M.; HANKE, M. L.; PIPER, M. G.; BAILEY, M. T.; BRINGARDNER, B. D.; SHERIDAN, J. F.; MARSH, C. B. Social disruption induces lung inflammation. Brain, Behavior, and Immunity, v. 24, n. 3, p. 394-402, 2010.

DATTI, F.; DATTI, M.; ANTUNES, E.; TEIXEIRA, N. A. Influence of chronic unpredictable stress on the allergic responses in rats. Physiology \& Behavior, v. 77, n. 1, p. 79-83, 2002.

DAYAS, C. V.; BULLER, K. M.; CRANE, J. W.; XU, Y.; DAY, T. A. Stressor categorization: acute physical and psychological stressors elicit distinctive recruitment patterns in the amygdala and in medullary noradrenergic cell groups. European Journal of Neuroscience, v. 14, n. 7, p. 1143-1152, 2001.

DE OLIVEIRA, A. P.; LINO-DOS-SANTOS-FRANCO, A.; HAMASATO, E. K.; QUINTEIRO-FILHO, W.; HEBEDA, C. B.; DAMAZO, A. S.; FARSKY, S. H.; TAVARESDE-LIMA, W.; PALERMO-NETO, J. Amphetamine modulates cellular recruitment and 
airway reactivity in a rat model of allergic lung inflammation. Toxicology letters, v. 200, n. $1-2$, p. 117-123, 2011.

DE VRIES, G. J.; VILLALBA, C. Brain Sexual Dimorphism and Sex Differences in Parental and Other Social Behaviors. Annals of the New York Academy of Sciences, v. 807, n. 1, p. 273-286, 1997.

DHABHAR, F. S.; MILLER, A. H.; STEIN, M.; MCEWEN, B. S.; SPENCER, R. L. Diurnal and acute stress-induced changes in distribution of peripheral blood leukocyte subpopulations. Brain, Behavior, and Immunity, v. 8, n. 1, p. 66-79, 1994.

DHABHAR, F. S.; MILLER, A. H.; MCEWEN, B. S.; SPENCER, R. L. Stress-induced changes in blood leukocyte distribution. Role of adrenal steroid hormones. Journal of Immunology, v. 157, n. 4, p. 1638-1644, 1996.

DHABHAR, F. S.; MCEWEN, B. S. Acute Stress Enhances while Chronic Stress Suppresses Cell-Mediated Immunityin Vivo:A Potential Role for Leukocyte Trafficking. Brain, Behavior, and Immunity, v. 11, n. 4, p. 286-306, 1997.

DHABHAR, F. S. Stress-induced augmentation of immune function--The role of stress hormones, leukocyte trafficking, and cytokines. Brain, Behavior, and Immunity, v. 16, n. 6, p. $785-798,2002$.

DHABHAR, F. S. Stress, Leukocyte Trafficking, and the Augmentation of Skin Immune Function. Annals of the New York Academy of Sciences, v. 992, n. 1, p. 205-217, 2003.

DUEZ, C.; DAKHAMA, A.; TOMKINSON, A.; MARQUILLIES, P.; BALHORN, A.; TONNEL, A. B.; BRATTON, D. L.; GELFAND, E. W. Migration and accumulation of eosinophils toward regional lymph nodes after airway allergen challenge. The Journal of Allergy and Clinical Immunology, v. 114, n. 4, p. 820-825, 2004.

ELENKOV, I. J.; CHROUSOS, G. P. Stress Hormones, Th1/Th2 patterns, Pro/Antiinflammatory Cytokines and Susceptibility to Disease. Trends in Endocrinology and Metabolism, v. 10, n. 9, p. 359-368, 1999.

ELENKOV, I. J.; WILDER, R. L.; CHROUSOS, G. P.; VIZI, E. S. The Sympathetic NerveAn Integrative Interface between Two Supersystems: The Brain and the Immune System. Pharmacological Reviews, v. 52, n. 4, p. 595-638, 2000.

ELENKOV, I. J.; CHROUSOS, G. P. Stress Hormones, Proinflammatory and Antiinflammatory Cytokines, and Autoimmunity. Annals of the New York Academy of Sciences, v. 966, n. 1, p. 290-303, 2002. 
ENGLER, H.; BAILEY, M. T.; ENGLER, A.; SHERIDAN, J. F. Effects of repeated social stress on leukocyte distribution in bone marrow, peripheral blood and spleen. Journal of Neuroimmunology, v. 148, n. 1-2, p. 106-115, 2004.

FINKELMAN, F.; HOGAN, S.; HERSHEY, G.; ROTHENBERG, M.; WILLS-KARP, M. Importance of cytokines in murine allergic airway disease and human asthma. Journal of Immunology, v. 184, n. 4, p. 1663-1674, 2010.

FORSYTHE, P.; EBELING, C.; GORDON, J. R.; BEFUS, A. D.; VLIAGOFTIS, H. Opposing effects of short- and long-term stress on airway inflammation. American Journal of Respiratory and Critical Care Medicine, v. 169, n. 2, p. 220-226, 2004.

GADEK-MICHALSKA, A.; TADEUSZ, J.; RACHWALSKA, P.; BUGAJSKI, J. Cytokines, prostaglandins and nitric oxide in the regulation of stress-response systems. Pharmacological Reports, v. 65, n. 6, p. 1655-62, 2013.

GUILlAMÓN, A.; SEGOVIA, S. Sex Differences in the Vomeronasal System. Brain Research Bulletin, v. 44, n. 4, p. 377-382, 1997.

GUPTA, M.; MAZUMDER, U. K.; KUMAR, R. S.; SIVAKUMAR, T.; VAMSI, M. L. M. Antitumor Activity and Antioxidant Status of $<\mathrm{i}>$ Caesalpinia bonducella $</ \mathrm{i}>$ Against Ehrlich Ascites Carcinoma in Swiss Albino Mice. Journal of Pharmacological Sciences, v. 94, n. 2, p. 177-184, 2004.

HAMASATO, E. K.; LIGEIRO DE OLIVEIRA, A. P.; LINO-DOS-SANTOS-FRANCO, A.; RIBEIRO, A.; FERRAZ DE PAULA, V.; PERON, J. P.; DAMAZO, A. S.; TAVARES-DELIMA, W.; PALERMO-NETO, J. Effects of MK-801 and amphetamine treatments on allergic lung inflammatory response in mice. International Immunopharmacology, v. 16, n. 4, p. 436-443, 2013.

HAMASATO, E. K.; DE LIMA, A. P. N.; DE OLIVEIRA, A. P. L.; DOS SANTOS FRANCO, A. L.; DE LIMA, W. T.; PALERMO-NETO, J. Cohabitation with a sick partner increases allergic lung inflammatory response in mice. Brain, Behavior, and Immunity, v. 42, p. 109-117, 2014.

HARTVEIT, F. The growth of Ehrlich's ascites carcinoma in $\mathrm{C} 3 \mathrm{H}$ mice and in mice of an unrelated closed colony. Variation in tumour growth, cytology and ascites formation. British Journal of Cancer, v. 20, n. 4, p. 818-824, 1966.

HAWRYLOWICZ, C. M.; O'GARRA, A. Potential role of interleukin-10-secreting regulatory T cells in allergy and asthma. Nature Review Immunology, v. 5, n. 4, p. 271-283, 2005. 
HOGAN, S. P.; KOSKINEN, A.; FOSTER, P. S. Interleukin-5 and eosinophils induce airway damage and bronchial hyperreactivity during allergic airway inflammation in BALB/c mice. Immunology and Cell Biology, v. 75, n. 3, p. 284-288, 1997.

HOLGATE, S. Pathogenesis of asthma. Clinical and Experimental Allergy, v. 38, n. 6, p. 872-897, 2008.

IIMORI, K., TANAKA, M., KOHNO, Y., IDA, Y., NAKAGAWA, R., HOAKI, Y., TSUDA, A., NAGASAKI, N. Psychological stress enhances noradrenaline turnover in specific brain regions in rats. Pharmacology, Biochemistry, and Behavior, v. 16, p. 637-640, 1982.

IWAKABE, K.; SHIMADA, M.; OHTA, A.; YAHATA, T.; OHMI, Y.; HABU, S.; NISHIMURA, T. The restraint stress drives a shift in Th1/Th2 balance toward Th2-dominant immunity in mice. Immunology Letters, v. 62, n. 1, p. 39-43, 1998.

JAHNG, J. W. An animal model of eating disorders associated with stressful experience in early life. Hormones and Behavior, v. 59, n. 2, p. 213-220, 2011.

JOHNSON, R. K.; JONDORF, W. R. Some inhibitory effects of (-)-emetine on growth of Ehrlich ascites carcinoma. Biochemical Journal, v. 140, n. 1, p. 87-94, 1974.

KAVALIERS, M.; COLWELL, D. D.; CHOLERIS, E. Parasites and Behaviour: An Ethopharmacological Perspective. Parasitology Today, v. 16, n. 11, p. 464-468, 2000.

KAVALIERS, M.; CHOLERIS, E.; PFAFF, D. W. Recognition and avoidance of the odors of parasitized conspecifics and predators: Differential genomic correlates. Neuroscience \& Biobehavioral Reviews, v. 29, n. 8, p. 1347-1359, 2005 a.

KAVALIERS, M.; CHOLERIS, E.; PFAFF, D. W. Genes, odours and the recognition of parasitized individuals by rodents. Trends in Parasitology, v. 21, n. 9, p. 423-429, 2005 b.

KELLY, M.; HWANG, J. M.; KUBES, P. Modulating leukocyte recruitment in inflammation. The Journal of Allergy and Clinical Immunology, v. 120, n. 1, p. 3-10, 2007.

KIECOLT-GLASER, J. K.; GLASER, R. Depression and immune function: Central pathways to morbidity and mortality. Journal of Psychosomatic Research, v. 53, n. 4, p. 873-876, 2002.

KINSEY, S. G.; BAILEY, M. T.; SHERIDAN, J. F.; PADGETT, D. A.; AVITSUR, R. Repeated social defeat causes increased anxiety-like behavior and alters splenocyte function in C57BL/6 and CD-1 mice. Brain, Behavior, and Immunity, v. 21, n. 4, p. 458-466, 2007. 
KITAGISHI, Y.; KOBAYASHI, M.; MATSUDA, S. Protection against Cancer with Medicinal Herbs via Activation of Tumor Suppressor. Journal of Oncology, v. 2012, p. $236530,2012$.

KOHM, A. P.; SANDERS, V. M. Norepinephrine: a messenger from the brain to the immune system. Immunology Today, v. 21, n. 11, p. 539-542, 2000.

KOHM, A. P.; SANDERS, V. M. Norepinephrine and $\beta 2$-Adrenergic Receptor Stimulation Regulate CD4+ T and B Lymphocyte Function in Vitro and in Vivo. Pharmacological Reviews, v. 53, n. 4, p. 487-525, 2001.

KUMAR, A.; D’SOUZA, S.; MYSORE NAGARAJ, S.; GAONKAR, S. L.; SALIMATH, B.; RAI, K. M. L. Antiangiogenic and antiproliferative effects of substituted-1,3,4-oxadiazole derivatives is mediated by down regulation of VEGF and inhibition of translocation of HIF$1 \alpha$ in Ehrlich ascites tumor cells. Cancer Chemotherapy and Pharmacology, v. 64, n. 6, p. 1221-1233, 2009.

KWAK, J.; OPIEKUN, M. C.; MATSUMURA, K.; PRETI, G.; YAMAZAKI, K.; BEAUCHAMP, G. K. Major histocompatibility complex-regulated odortypes: Peptide-free urinary volatile signals. Physiology \& Behavior, v. 96, n. 1, p. 184-188, 2009.

LAMBRECHT, B. N.; KOOL, M.; WILLART, M. A. M.; HAMMAD, H. Mechanism of action of clinically approved adjuvants. Current Opinion in Immunology, v. 21, n. 1, p. 23 29, 2009.

LEWIS, C.; ARONOW, B.; HUTTON, J.; SANTELIZ, J.; DIENGER, K.; HERMAN, N.; FINKELMAN, F.; WILLS-KARP, M. Unique and overlapping gene expression patterns driven by IL-4 and IL-13 in the mouse lung. The Journal of Allergy and Clinical Immunology, v. 123, n. 4, p. 795-804.e798, 2009.

LI, B.; DUAN, X. H.; WU, J. F.; LIU, B. J.; LUO, Q. L.; JIN, H. L.; DU, Y. J.; ZHANG, H. Y.; CAO, Y. X.; DONG, J. C. Impact of psychosocial stress on airway inflammation and its mechanism in a murine model of allergic asthma. Chinese Medical Journal (Engl), v. 126, n. 2, p. 325-334, 2013.

LIGEIRO-OLIVEIRA, A.; FIALHO DE ARAÚJO, A.; LAZZARINI, R.; SILVA, Z.; DE NUCCI, G.; MUSCARÁ, M.; TAVARES DE LIMA, W.; PALERMO-NETO, J. Effects of amphetamine on immune-mediated lung inflammatory response in rats.

Neuroimmunomodulation, v. 11, n. 3, p. 181-190, 2004.

LIGHTMAN, S. L.; WINDLE, R. J.; MA, X. M.; HARBUZ, M. S.; SHANKS, N. M.; JULIAN, M. D.; WOOD, S. A.; KERSHAW, Y. M.; INGRAM, C. D. Hypothalamicpituitary-adrenal function. Archives of Physiology and Biochemistry, v. 110, n. 1-2, p. 9093, 2002. 
LINO DOS SANTOS FRANCO, A.; DAMAZO, A. S.; BERALDO DE SOUZA, H. R.; DOMINGOS, H. V.; OLIVEIRA-FILHO, R. M.; OLIANI, S. M.; COSTA, S. K.; TAVARES DE LIMA, W. Pulmonary neutrophil recruitment and bronchial reactivity in formaldehydeexposed rats are modulated by mast cells and differentially by neuropeptides and nitric oxide. Toxicology and Applied Pharmacology, v. 214, n. 1, p. 35-42, 2006.

LISTER, R. G. The use of a plus-maze to measure anxiety in the mouse.

Psychopharmacology, v. 92, n. 2, p. 180-185, 1987.

LIVAK, K. J.; SCHMITTGEN, T. D. Analysis of Relative Gene Expression Data Using RealTime Quantitative PCR and the 2- $\Delta \Delta$ CT Method. Methods, v. 25, n. 4, p. 402-408, 2001.

LONSTEIN, J. S.; DE VRIES, G. J. Sex differences in the parental behavior of rodents. Neuroscience \& Biobehavioral Reviews, v. 24, n. 6, p. 669-686, 2000.

LUCAS, K.; MAES, M. Role of the Toll Like Receptor (TLR) Radical Cycle in Chronic Inflammation: Possible Treatments Targeting the TLR4 Pathway. Molecular Neurobiology, v.48, n.1, p.190-204, 2013.

MACHADO, T. R. M. Alterações neuroimunes induzidas em camundongos machos pela convivência com um companheiro doente. 2013. 147 p. Dissertação (Mestrado em Ciências) - Faculdade de Medicina Veterinária e Zootecnia, Universidade de São Paulo, São Paulo, 2013.

MADDEN, K. S.; SANDERS, V. M.; FELTEN, D. L. Catecholamine influences and sympathetic neural modulation of immune responsiveness. Annual Review of Pharmacology and Toxicology, v. 35, p. 417-448, 1995.

MARSHALL, G. D., JR.; AGARWAL, S. K.; LLOYD, C.; COHEN, L.; HENNINGER, E. M.; MORRIS, G. J. Cytokine dysregulation associated with exam stress in healthy medical students. Brain, Behavior, and Immunity, v. 12, n. 4, p. 297-307, 1998.

MARTIN, T. R.; FREVERT, C. W. Innate immunity in the lungs. Proceedings of the American Thoracic Society, v. 2, n. 5, p. 403-411, 2005.

MASINI, C. V.; DAY, H. E. W.; GRAY, T.; CREMA, L. M.; NYHUIS, T. J.; BABB, J. A.; CAMPEAU, S. Evidence for a lack of phasic inhibitory properties of habituated stressors on HPA axis responses in rats. Physiology \& Behavior, v. 105, n. 2, p. 568-575, 2012.

MATSUMOTO, A.; ARAI, Y. Development of sexual dimorphism in synaptic organization in the ventromedial nucleus of the hypothalamus in rats. Neuroscience Letters, v. 68, n. 2, p. 165-168, 1986. 
MATSUMURA, K.; OPIEKUN, M.; OKA, H.; VACHANI, A.; ALBELDA, S. M.; YAMAZAKI, K.; BEAUCHAMP, G. K. Urinary Volatile Compounds as Biomarkers for Lung Cancer: A Proof of Principle Study Using Odor Signatures in Mouse Models of Lung Cancer. PLoS One, v. 5, n. 1, p. e8819, 2010.

MAYER, K. D. The pathogenicity of the Ehrlich ascites tumour. British Journal of Experimental Pathology, v. 47, n. 5, p. 537-544, 1966.

MORGULIS, M. S.; STANKEVICIUS, D.; SA-ROCHA, L. C.; PALERMO-NETO, J. Cohabitation with a sick cage mate: consequences on behavior and on ehrlich tumor growth. Neuroimmunomodulation, v. 11, n. 1, p. 49-57, 2004.

NAGY, J. A.; HERZBERG, K. T.; MASSE, E. M.; ZIENTARA, G. P.; DVORAK, H. F. Exchange of Macromolecules between Plasma and Peritoneal Cavity in Ascites Tumorbearing, Normal, and Serotonin-injected Mice. Cancer Research, v. 49, n. 19, p. 5448-5458, 1989.

NEUMANN, I. D.; JOHNSTONE, H. A.; HATZINGER, M.; LIEBSCH, G.; SHIPSTON, M.; RUSSELL, J. A.; LANDGRAF, R.; DOUGLAS, A. J. Attenuated neuroendocrine responses to emotional and physical stressors in pregnant rats involve adenohypophysial changes. The Journal of Physiology, v. 508, n. Pt 1, p. 289-300, 1998.

NGOC, P.; NGOC, L.; GOLD, D.; TZIANABOS, A.; WEISS, S.; CELEDÓN, J. Cytokines, allergy, and asthma. Current Opinion in Allergy and Clinical Immunology, v. 5, n. 2, p. 161-166, 2005.

NGUYEN, T.-H. T.; CASALE, T. B. Immune modulation for treatment of allergic disease. Immunological Reviews, v. 242, n. 1, p. 258-271, 2011.

NURIEVA, R. I.; CHUNG, Y. Understanding the development and function of T follicular helper cells. Cellular \& Molecular Immunology, v. 7, n. 3, p. 190-197, 2010.

OKUYAMA, K.; OHWADA, K.; SAKURADA, S.; SATO, N.; SORA, I.; TAMURA, G.; TAKAYANAGI, M.; OHNO, I. The distinctive effects of acute and chronic psychological stress on airway inflammation in a murine model of allergic asthma. Allergology International, v. 56, n. 1, p. 29-35, 2007.

OTTAWAY, C. A.; HUSBAND, A. J. The influence of neuroendocrine pathways on lymphocyte migration. Immunology Today, v. 15, n. 11, p. 511-517, 1994.

PALERMO-NETO, J.; GUIMARÃES, R. Pavlovian conditioning of lung anaphylactic response in rats. Life Sciences, v. 68, n. 6, p. 611-623, 2000. 
PALERMO-NETO, J.; DE OLIVEIRA MASSOCO, C.; ROBESPIERRE DE SOUZA, W. Effects of physical and psychological stressors on behavior, macrophage activity, and Ehrlich tumor growth. Brain, Behavior, and Immunity, v. 17, n. 1, p. 43-54, 2003.

PALERMO-NETO, J.; FONSECA, E. S.; QUINTEIRO-FILHO, W. M.; CORREIA, C. S.; SAKAI, M. Effects of individual housing on behavior and resistance to Ehrlich tumor growth in mice. Physiology \& Behavior, v. 95, n. 3, p. 435-440, 2008.

PALERMO-NETO, J.; ALVES, G. J. Neuroimmune Interactions And Psychologycal Stress Induced By Cohabitation With A Sick Partner: A Review. Current Pharmaceutical Design, v. 20, n.29, p. 4629-41, 2014.

PALERMO NETO, J.; MASSOCO, C. O.; FAVARE, R. C. Effects of maternal stress on anxiety levels, macrophage activity, and Ehrlich tumor growth. Neurotoxicology and Teratology, v. 23, n. 5, p. 497-507, 2001.

PAXINOS, G.; WATSON, C. The mouse brain in stereotaxic coordinates. Elsevier: Academic Press, 1998.

PELLOW, S.; CHOPIN, P.; FILE, S. E.; BRILEY, M. Validation of open : closed arm entries in an elevated plus-maze as a measure of anxiety in the rat. Journal of Neuroscience Methods, v. 14, n. 3, p. 149-167, 1985.

PENN, D.; POTTS, W. K. Chemical signals and parasite-mediated sexual selection. Trends in Ecology \& Evolution, v. 13, n. 10, p. 391-396, 1998.

PORTELA, P.; MASSOCO CDE, O.; DE LIMA, W. T.; PALERMO-NETO, J. Stressinduced increment on total bronchoalveolar cell count in OVA-sensitized rats. Physiology \& Behavior, v. 72, n. 3, p. 415-420, 2001.

POWELL, N. D.; TARR, A. J.; SHERIDAN, J. F. Psychosocial stress and inflammation in cancer. Brain, Behavior, and Immunity, v. 30 Suppl, p. S41-47, 2013.

QUARCOO, D.; PAVLOVIC, S.; JOACHIM, R. Stress and airway reactivity in a murine model of allergic airway inflammation. Neuroimmunomodulation, v. 16, n. 5, p. 318-324, 2009.

QUINTEIRO-FILHO, W. M.; RIGHI, D. A.; PALERMO-NETO, J. Effect of cyhalothrin on Ehrlich tumor growth and macrophage activity in mice. Brazilian Journal of Medical and Biological Research, v. 42, n. 10, p. 912-917, 2009. 
RENAULD, J.-C. New insights into the role of cytokines in asthma. Journal of Clinical Pathology, v. 54, n. 8, p. 577-589, 2001.

ROBINSON, D. S.; HAMID, Q.; YING, S.; TSICOPOULOS, A.; BARKANS, J.; BENTLEY, A. M.; CORRIGAN, C.; DURHAM, S. R.; KAY, A. B. Predominant TH2-like Bronchoalveolar T-Lymphocyte Population in Atopic Asthma. New England Journal of Medicine, v. 326, n. 5, p. 298-304, 1992.

ROHLEDER, N.; ARINGER, M.; BOENTERT, M. Role of interleukin-6 in stress, sleep, and fatigue. Annals of the New York Academy of Sciences, v. 1261, n. 1, p. 88-96, 2012.

ROSENKRANZ, M. A.; BUSSE, W. W.; JOHNSTONE, T.; SWENSON, C. A.; CRISAFI, G. M.; JACKSON, M. M.; BOSCH, J. A.; SHERIDAN, J. F.; DAVIDSON, R. J. Neural circuitry underlying the interaction between emotion and asthma symptom exacerbation.

Proceedings of the National Academy of Sciences of the United States of America, v. 102, n. 37, p. 13319-13324, 2005.

SABBAN, E.L., KVETNANSKY, R. Stress-triggered activation of gene expression in catecholaminergic systems: dynamics of transcriptional events. Trends in Neurosciences, $v$. 24, p. 91-98, 2001.

SAKAI, M.; FONSECA, E. S. M.; OLORIS, S. C. S.; MATSUZAKI, P.; OTAKE, A. H.; LEITE, K. R. M.; MASSOCO, C. O.; DAGLI, M. L. Z.; PALERMO-NETO, J. Effects of peripheral-type benzodiazepine receptor ligands on Ehrlich tumor cell proliferation.

European Journal of Pharmacology, v. 550, n. 1-3, p. 8-14, 2006 a.

SAKAI, M.; FONSECA, E. S.; DAGLI, M. L.; PALERMO-NETO, J. Diazepam effects on Ehrlich tumor growth and macrophage activity in mice. Life Sciences, v. 78, n. 16, p. 17771783, 2006b.

SAKAI, M.; FERRAZ-DE-PAULA, V.; PINHEIRO, M. L.; RIBEIRO, A.; QUINTEIROFILHO, W. M.; RONE, M. B.; MARTINEZ-ARGUELLES, D. B.; DAGLI, M. L.; PAPADOPOULOS, V.; PALERMO-NETO, J. Translocator protein $(18 \mathrm{kDa})$ mediates the pro-growth effects of diazepam on Ehrlich tumor cells in vivo. European Journal of Pharmacology, v. 626, n. 2-3, p. 131-138, 2010.

SANDERS, V. M.; KASPROWICZ, D. J.; SWANSON-MUNGERSON, M. A.; PODOJIL, J. R.; KOHM, A. P. Adaptive immunity in mice lacking the beta(2)-adrenergic receptor. Brain, Behavior, and Immunity, v. 17, n. 1, p. 55-67, 2003.

SCHUIJS, M. J.; WILLART, M. A.; HAMMAD, H.; LAMBRECHT, B. N. Cytokine targets in airway inflammation. Current Opinion in Pharmacology, v. 13, n. 3, p. 351-361, 2013. 
SCOLA, A. M.; LOXHAM, M.; CHARLTON, S. J.; PEACHELL, P. T. The long-acting betaadrenoceptor agonist, indacaterol, inhibits IgE-dependent responses of human lung mast cells. British Journal of Pharmacology, v. 158, n. 1, p. 267-276, 2009.

SEQUEIRA-CORDERO, A.; MORA-GALLEGOS, A.; CUENCA-BERGER, P.; FORNAGUERA-TRÍAS, J. Individual differences in the forced swimming test and the effect of environmental enrichment: Searching for an interaction. Neuroscience, v. 265, n. 0, p. 95107, 2014.

SHANG, L. H.; LUO, Z. Q.; DENG, X. D.; WANG, M. J.; HUANG, F. R.; FENG, D. D.; YUE, S. J. Expression of N-methyl-d-aspartate receptor and its effect on nitric oxide production of rat alveolar macrophages. Nitric Oxide, v. 23, n. 4, p. 327-331, 2010.

STEFANSKI, V. Social stress in laboratory rats: hormonal responses and immune cell distribution. Psychoneuroendocrinology, v. 25, n. 4, p. 389-406, 2000.

SUGITA, M.; KURIBAYASHI, K.; NAKAGOMI, T.; MIYATA, S.; MATSUYAMA, T.; KITADA, O. Allergic bronchial asthma: airway inflammation and hyperresponsiveness. Internal Medicine, v. 42, n. 8, p. 636-643, 2003.

SUTHERLAND, M. A.; SHOME, G. P.; HULBERT, L. E.; KREBS, N.; WACHTEL, M.; MCGLONE, J. J. Acute stress affects the physiology and behavior of allergic mice.

Physiology \& Behavior, v. 98, n. 3, p. 281-287, 2009.

TAILOR, P.; TAMURA, T.; OZATO, K. IRF family proteins and type I interferon induction in dendritic cells. Cell Research, v. 16, n. 2, p. 134-140, 2006.

TAKAHASHI, L. K. Olfactory systems and neural circuits that modulate predator odor fear. Frontiers in Behavioral Neuroscience, v. 8, n.72, p.1-13, 2014.

TANAKA, M., KOHNO, Y., NAKAGAWA, R., IDA, Y., TAKEDA, S., NAGASAKI, N. Time-related differences in noradrenaline turnover in rat brain regions by stress.

Pharmacology, Biochemistry, and Behavior, v. 16, p. 315-319, 1982.

TAUSK, F.; ELENKOV, I.; MOYNIHAN, J. Psychoneuroimmunology. Dermatologic Therapy, v. 21, n. 1, p. 22-31, 2008.

TOMIYOSHI, M. Y.; SAKAI, M.; BALEEIRO, R. B.; STANKEVICIUS, D.; MASSOCO, C. O.; PALERMO-NETO, J.; BARBUTO, J. A. Cohabitation with a B16F10 melanomabearer cage mate influences behavior and dendritic cell phenotype in mice. Brain, Behavior, and Immunity, v. 23, n. 4, p. 558-567, 2009. 
TONELLI, L. H.; KATZ, M.; KOVACSICS, C. E.; GOULD, T. D.; JOPPY, B.; HOSHINO, A.; HOFFMAN, G.; KOMAROW, H.; POSTOLACHE, T. T. Allergic rhinitis induces anxiety-like behavior and altered social interaction in rodents. Brain, Behavior, and Immunity, v. 23, n. 6, p. 784-793, 2009.

TORRES, K. C.; ANTONELLI, L. R.; SOUZA, A. L.; TEIXEIRA, M. M.; DUTRA, W. O.; GOLLOB, K. J. Norepinephrine, dopamine and dexamethasone modulate discrete leukocyte subpopulations and cytokine profiles from human PBMC. Journal of Neuroimmunology, v. 166, n. 1-2, p. 144-157, 2005.

TOURNOY, K. G.; KIPS, J. C.; SCHOU, C.; PAUWELS, R. A. Airway eosinophilia is not a requirement for allergen-induced airway hyperresponsiveness. Clinical and Experimental Allergy, v. 30, n. 1, p. 79-85, 2000.

TRUEBA, A. F.; RITZ, T. Stress, asthma, and respiratory infections: pathways involving airway immunology and microbial endocrinology. Brain, Behavior, and Immunity, v. 29, p. 11-27, 2013.

VALENTINO, R. J.; VAN BOCKSTAELE, E. Convergent regulation of locus coeruleus activity as an adaptive response to stress. European Journal of Pharmacology, v. 583, n. 23, p. 194-203, 2008.

VALENTINO, R. J.; REYES, B.; VAN BOCKSTAELE, E.; BANGASSER, D. Molecular and cellular sex differences at the intersection of stress and arousal. Neuropharmacology, $\mathrm{v}$. 62 , n. 1, p. 13-20, 2012.

VANIOTIS, G.; GLAZKOVA, I.; MERLEN, C.; SMITH, C.; VILLENEUVE, L. R.; CHATENET, D.; THERIEN, M.; FOURNIER, A.; TADEVOSYAN, A.; TRIEU, P.; NATTEL, S.; HEBERT, T. E.; ALLEN, B. G. Regulation of cardiac nitric oxide signaling by nuclear beta-adrenergic and endothelin receptors. Journal of Molecular and Cellular Cardiology, v. 62, p. 58-68, 2013.

VIEIRA, J.; MATSUZAKI, P.; NAGAMINE, M. K.; HARAGUCHI, M.; AKISUE, G.; GORNIAK, S. L.; DAGLI, M. L. Z. Inhibition of ascitic ehrlich tumor cell growth by intraperitoneal injection of Pfaffia paniculata (Brazilian ginseng) butanolic residue. Brazilian Archives of Biology and Technology, v. 53, p. 609-613, 2010.

VLIAGOFTIS, H. Psychological Stress and Asthma: A New Enemy Within. International Archives of Allergy and Immunology, v. 164, n. 2, p. 109-111, 2014.

WILLS-KARP, M.; GAVETT, S.; SCHOFIELD, B.; FINKELMAN, F. Role of interleukin-4 in the development of allergic airway inflammation and airway hyperresponsiveness.

Advances in Experimental Medicine and Biology, v. 409, p. 343-347, 1996. 
YUSUF-MAKAGIANSAR, H.; ANDERSON, M.; YAKOVLEVA, T.; MURRAY, J.; SIAHAAN, T. Inhibition of LFA-1/ICAM-1 and VLA-4/VCAM-1 as a therapeutic approach to inflammation and autoimmune diseases. Medical Research Reviews, v. 22, n. 2, p. 146$167,2002$.

ZHANG, S.; SHEN, Z.; HU, G.; LIU, R.; ZHANG, X. Effects of endogenous glucocorticoids on allergic inflammation and $\mathrm{TH} 1 / \mathrm{TH} 2$ balance in airway allergic disease. Annals of Allergy, Asthma \& Immunology, v. 103, n. 6, p. 525-534, 2009.

ZOSKY, G.; SLY, P. Animal models of asthma. Clinical and Experimental Allergy, v. 37, n. 7, p. 973-988, 2007. 


\section{ANEXO A}

\section{Cohabitation with a sick partner increases allergic lung inflammatory response in mice}

Eduardo Kenji Hamasato ${ }^{a}$, Ana Paula Nascimento de Lima a , Ana Paula Ligeiro de Oliveira ${ }^{\text {, }}$, Adriana Lino dos Santos Franco ${ }^{c}$, Wothan Tavares de Limad ${ }^{d}$, João Palermo-Neto ${ }^{\text {a,* }}$

${ }^{a}$ Neuroimmunomodulation Research Group, Department of Pathology, School of Veterinary Medicine, University of São Paulo, São Paulo, SP, Brazil

${ }^{\mathrm{b}}$ Post Graduate Program in Biophotonics Applied to Health Sciences, Nove de Julho University, UNINOVE, São Paulo, Brazil

${ }^{c}$ Department of Clinical and Toxicological Analyses, Faculty of Pharmaceutical Sciences, University of São Paulo, São Paulo, Brazil

${ }^{\mathrm{d} D e p a r t m e n t ~ o f ~ P h a r m a c o l o g y, ~ U n i v e r s i t y ~ o f ~ S a ̃ o ~ P a u l o, ~ S a ̃ o ~ P a u l o, ~ B r a z i l ~}$

A R T I C L E I N F O

\section{Article history:}

Received in revised form 22 May 2014

Accepted 3 June 2014

Available online 11 June 2014

Keywords:

Ehrlich tumor

Asthma

Allergic lung inflammation

Inflammatory mediators

Adhesion molecules

Cytokines

Airways reactivity

Catecholamine

\begin{abstract}
A B S T R A C T
The bidirectional relationship between the nervous system and the immune system is relevant for homeostatic organism maintenance. Studies from our laboratory showed that 14 days of cohabitation with a sick partner (injected with Ehrlich tumor cells-TAE) produced behavioral, neurochemical, endocrinological and immunological changes. This study analyzes the effects of cohabitation with an Ehrlich tumor-bearing animal on ovalbumin (OVA)-induced lung inflammatory response in mice. Pairs of male mice were divided into three groups: naïve, control and experimental. Animals of the naïve group were kept undisturbed being used for the assessment of basal parameters. One animal of each experimental and control pair of mice was immunized with OVA. On $\mathrm{ED}_{(0)}$, these OVA-immunized animals received an OVA booster. At this day $\left(D_{(0)}\right)$ the experimental mice that were kept undisturbed were inoculated with $5 \times 10^{6}$ Ehrlich tumor cells; their immunized cage-mates were then referred as to CSP ("companion of sick partner"). The undisturbed mice of each control pair were i.p. treated on $\mathrm{D}_{(0)}$ with $0.9 \% \mathrm{NaCl}$; their sensitized cage-mates were subsequently referred as CHP ("companion of health partner"). The OVA challenge was performed on CSP and $\mathrm{CHP}$ mice on $\mathrm{ED}_{(12)}$ and $\mathrm{ED}_{(13)}$; blood and tissue collection were performed on $\mathrm{ED}_{(14)}$. Fourteen days after cohabitation, in comparison to the CHP mice, the CSP mice displayed the following: (1) an increased number of eosinophils and neutrophils in the BAL (2) a decreased bone marrow cell count, (3) increased levels of IL- 4 and IL- 5 and decreased levels of IL-10 and IFN- $\gamma$ in the BAL supernatant, (5) increased levels of IgG1-OVA, decreased levels of IgG2a-OVA and no changes in OVA-specific IgE in the peripheral blood, (6) increased expression of L-selectin in the BAL granulocytes, (7) decreased tracheal reactivity to methacholine measured in vitro, (8) no changes in plasma corticosterone levels and (9) increased levels of plasmatic noradrenaline. These results suggest that allergic lung inflammatory response exacerbation in CSP mice is a consequence of the psychological stress induced by forced cohabitation with the sick partner. Strong involvement of the sympathetic nervous system (SNS) through adrenaline and noradrenaline release and a shift of the Th1/Th2 cytokine profile toward a Th2 response were considered to be the mechanisms underlying the cell recruitment to the animal's airways.
\end{abstract}

2014 Elsevier Inc. All rights reserved.

\section{Introduction}

The long-held view that homeostatic mechanisms are integrated by the nervous and endocrine systems has been expanded by information that these systems interact with the immune system (Ader et al., 1990; Dunn and Wang, 1995). Changes in cell-mediated

* Corresponding author. Address: Department of Pathology, School of Veterinary Medicine, University of São Paulo, Av, Prof. Dr. Orlando Marques de Paiva, $n^{\circ} 87$ CEP: 05508-270 Cidade Universitária, São Paulo, SP, Brazil

E-mail address: jpalermo@usp.br (J. Palermo-Neto). immune function were reported in individuals undergoing distressing life experiences (Gold, 1988; Nagata et al., 1999). Stressors were reported to decrease immune/inflammatory responses (Elenkov et al., 1999; Costa-Pinto and Palermo-Neto, 2010) and to modulate cytokine and peptide production and release (Besedovsky et al., 1986; Theoharides et al., 1995; Elenkov and Chrousos, 1999a) among others, through Hypothalamic-Pituitary-Adrenal (HPA) axis or Sympathetic Nervous System (SNS) activations.

Ehrlich tumor cells were reported to elicit a strong host inflammatory/immune response (Segura et al., 1997; Palermo-Neto et al. $2003,2008)$, a fact that, together with other properties, makes this 
tumor an interesting experimental model for the analysis of tumor growth. The data from our laboratory have shown that 14 days of cohabitation of mice with an Ehrlich tumor-bearing conspecific individual increased their locomotor activity within an open-field apparatus (Morgulis et al., 2004), decreased neutrophil and macrophage oxidative burst and phagocytosis in response to induction by myristate acetate or Staphylococcus aureus (Alves et al., 2006, 2007), decreased the animal's host resistance to tumor growth (Morgulis et al., 2004), decreased the levels and increased the turnover rate of noradrenaline within the hypothalamus (Alves et al., 2006), increased plasma levels of noradrenaline and adrenaline (Alves and Palermo-Neto, 2014) and induced no changes in corticosterone serum levels (Alves et al., 2006, 2012). Immune impairment has also been observed in companions of B16F10 melanoma-bearing mice (Tomiyoshi et al., 2009). These effects were discussed as being a consequence of the stress imposed by the housing condition. Indeed, it was shown that odor cues released by Ehrlich tumor-bearing mice are aversive to their partners, increasing their plasma levels of noradrenaline and adrenaline, consistent with a SNS activation hypothesis (Alves and Palermo-Neto, 2014).

The existence of interactions between emotional or psychopathological disorders and allergic and/or chronic diseases such as asthma is well established (Nagata et al., 1999; Vamos and Kolbe 1999; Rietveld et al., 2000). Asthma is a multifunctional disease characterized by pulmonary cellular infiltration, plasma exudation and airway hyper-responsiveness, the latter of which is globally related to the toxic effects of mediators released into the lungs by alveolar macrophages, neutrophils, eosinophils and mast cells (Bochner and Busse, 2005). Studies concerning emotional impacts on immune responses usually employ animal models of aversive stimulation to evaluate an antigen-induced inflammatory response (Persoons et al., 1995; Costa-Pinto and Palermo-Neto, 2010). Airway inflammation induced by ovalbumin (OVA) aerosol challenge in OVA-sensitized animals mimicked some pathological characteristics of asthma, e.g., peribronchial edema and increased number of lymphocytes and eosinophils in the bronchoalveolar lavage fluid (Portela et al., 2001, 2002). These events were augmented by early-life psychological stress (Chida et al., 2007), unpredictable stressor procedures (Datti et al., 2002), foot shock stress (Portela et al., 2001, 2002) and chemically-induced stressors (Ligeiro de Oliveira et al., 2012; Stankevicius et al.,2012; Hamasato et al., 2013).

Stressors are known to shift the Th1/Th2 cytokine balance toward a Th2 cytokine profile, thus suppressing Th1 and upregulating Th2 responses (Elenkov and Chrousos, 1999b), and deregulation of the Th1/Th2 cytokine balance is a key to the pathogenesis of asthma and atopic diseases (Marshall et al., 1998; Ngoc et al., 2005). The over-production of Th2 cytokines results in the recruitment and activation of inflammatory mediators, including mast cells, basophils, and eosinophils, further resulting in airway obstruction (Finkelman et al., 2010). The present study was thus specially designed to analyze the effects of 14 days of cohabitation with an Ehrlich tumor-bearing conspecific on OVA-sensitized and challenged mice, considering the following: cell trafficking into the bronchoalveolar lavage fluid, Th1 and Th2 cytokine production, immunoglobulin plasma levels, adhesion molecule expression, in vitro tracheal reactivity, corticosterone serum levels and plasma catecholamine levels.

\section{Materials and methods}

\subsection{Animals}

Male Balb/c mice (25-35 g, 8 weeks) from our departmental facilities were used. The animals were maintained under a controlled temperature $\left(22-24^{\circ} \mathrm{C}\right)$ and a 12 -h light/dark cycle with free access to food and water. The animals were housed in plastic cages and were handled and used in accordance with the guidelines of the Bioethical Committee for the Care and Use of Laboratory Animal Resources of the School of Veterinary Medicine of the University of São Paulo, Brazil (protocol No.2595/2012); these guidelines are similar to those of the National Institutes of Health (NIH), USA.

\subsection{Group formation and induction of allergy}

Fig. 1 depicts the protocol used in this study. Experiments were performed according to Good Laboratory Practice (GLP) standards and quality assurance methods. After a habituation period of 8 days, twenty pairs of mice were at random divided into three groups: naïve (4 pairs) control ( 8 pairs) and experimental ( 8 pairs). Care was taken to avoid possible stress induced by social hierarchies' establishment. For that, the paired mice were taken from the same cage colony. Fights and/or confrontations were not seen throughout the 8 days of previous cohousing. Animals of the naïve group $(\mathrm{N})$ were kept undisturbed from $\mathrm{ED}_{(-8)}$ (Experimental day-8) to $\mathrm{ED}_{(13)}$. On $\mathrm{ED}_{(-7)}$, one animal of each experimental and control pair of mice was subcutaneously (s.c.) immunized with a suspension of $10 \mu \mathrm{g}$ OVA (Egg Albumin Grade V, Sigma Chemical Company ${ }^{\circledast}$, USA) plus $10 \mathrm{mg}$ of aluminum hydroxide. On $\mathrm{ED}_{(0)}$, these OVA-immunized animals received a s.c. OVA booster injection $\left(10 \mu \mathrm{g}\right.$ OVA plus $10 \mathrm{mg} \mathrm{Al}(\mathrm{OH})_{3}$. At this day $\left(\mathrm{D}_{(0)}\right)$ the experimental mice that were kept undisturbed were inoculated with $5 \times 10^{6}$ Ehrlich tumor cells intraperitoneally (i.p.); their immunized cagemates were then referred as to CSP ("companion of sick partner"). The undisturbed mice of each control pair were i.p. treated on $\mathrm{D}_{(0)}$ with $0.9 \% \mathrm{NaCl}$; their sensitized cage-mates were subsequently referred as CHP ("companion of health partner"). The pairs of mice were left to cohabitate in the same cage for 14 days; confrontations or fights were not seen during this time period. On $\mathrm{ED}_{(12)}$ and $\mathrm{ED}_{(13)}$, the CHP and CSP mice, the subjects of this study, were anesthetized with isofluorene and subsequently intranasally challenged with two drops of a 1\% OVA solution, as suggested by (Zosky and Sly, 2007). On $\mathrm{ED}_{(14)}$, the Ehrlich tumor-injected mice were scored for Ehrlich tumor clinical signs and symptoms as suggested elsewhere (Tomiyoshi et al., 2009; Alves et al., 2010, 2012). Tissues were collected from the N, CSP and CHP mice on $\mathrm{ED}_{(14)}$.

\subsection{Leukocyte recruitment in the bronchoalveolar lavage fluid (BAL)}

On $\mathrm{ED}_{(14)}$, the lungs of the $\mathrm{N}, \mathrm{CSP}$ and CHP mice were lavaged with $1.5 \mathrm{~mL}$ phosphate-buffered saline (PBS) solution through a cannula inserted into the trachea. The recovered BAL (approximately $1 \mathrm{~mL}$ ) was centrifuged $\left(250 \mathrm{~g}\right.$ for $5 \mathrm{~min}$ at $\left.20^{\circ} \mathrm{C}\right)$, and the resulting cell pellet was suspended again in $1 \mathrm{~mL}$ of PBS. Cell suspensions $(90 \mu \mathrm{l})$ were stained with $10 \mu \mathrm{l}$ of $0.2 \%$ crystal violet, and the total cell number was determined in Neubauer chambers using a light microscope. Differential cell counts were performed with cytocentrifuge preparations (Cytospin, Fanem, São Paulo, Brazil) that were stained with Rosenfeld's dye using standard morphological criteria.

\subsection{Quantification of blood leukocytes and bone marrow cells}

Blood aliquots taken from the abdominal aorta of N, CSP and CHP mice on $\mathrm{ED}_{(14)}$ were diluted 1:20 in Turk's fluid (3\% acetic acid) for total white blood cell counting with an automatic cell counter (ABC Vet ${ }^{\circledR}$, São Paulo, Brazil). The total number of bone marrow cells taken from the mice was quantified from the femoral marrow lavage fluid. The recovered bone marrow lavage $(5 \mathrm{~mL})$ was centrifuged $\left(250 \mathrm{~g}\right.$ for $5 \mathrm{~min}$ at $20^{\circ} \mathrm{C}$ ). The supernatant was 


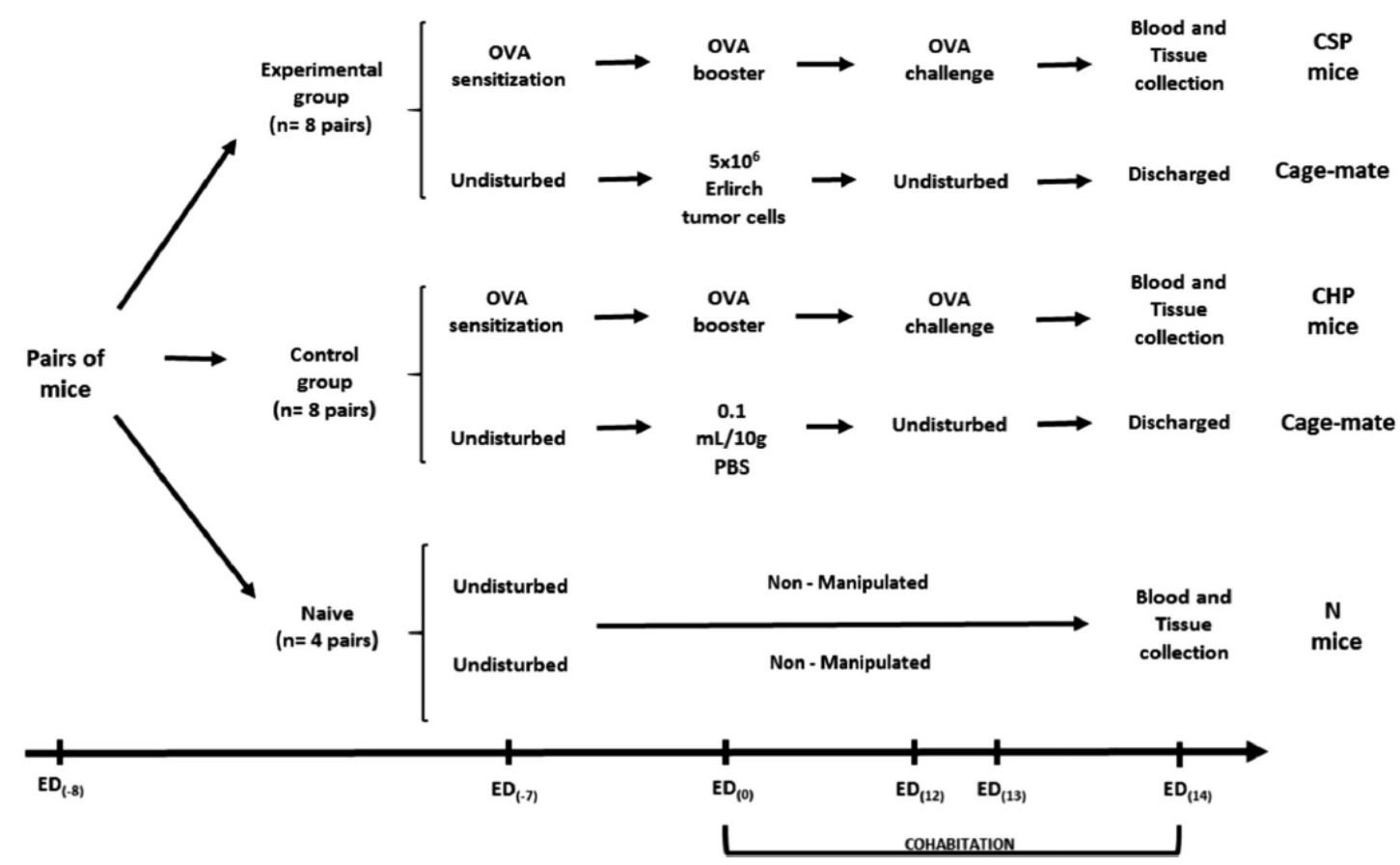

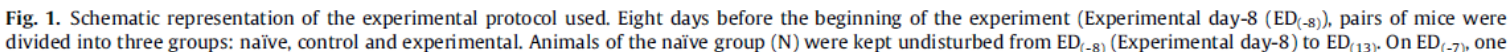

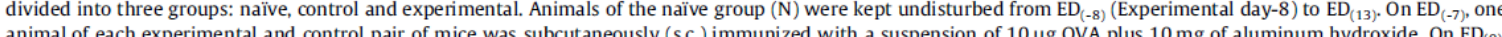
animal of each expenental and control pair of mice was subcutaneously (s.c.) immunized with a suspension or $10 \mu \mathrm{g} O \mathrm{OVA}$ plus 10 mg of aluminum hydroxide. On $\mathrm{ED}_{(0)}$ these OVA-immunized animals received a s.c. OVA booster injection. At this day $\left(\mathrm{D}_{(0)}\right)$ the experimental mice that were kept undisturbed were inoculated with $5 \times 10^{6}$ Ehrlich tumor cells intraperitoneally (i.p.); their immunized cage-mates were then referred as to CSP ("companion of sick partner"). The undisturbed mice of each control pair were i.p. treated on $\mathrm{D}_{(0)}$ with $0.9 \% \mathrm{NaCl}$; their sensitized cage-mates were subsequently referred as CHP ("companion of health partner"). The OVA challenge was performed on CSP and $\mathrm{CHP}$ mice on $\mathrm{ED}_{(12)}$ and $\mathrm{ED}_{(13)}$; blood and tissue collection were performed in $\mathrm{N}, \mathrm{CHP}$ and $\mathrm{CHP}$ mice on $\mathrm{ED}_{(14)}$

discarded and the pellet was resuspended in $1 \mathrm{~mL}$ PBS, stained with crystal violet $(0.2 \%)$ and quantified by optical microscopy, as described above.

\subsection{Quantification of cytokines in the BAL supernatant}

IL-4, IL-5, IL-10 and IFN- $\gamma$ levels were determined in samples of BAL supernatant taken from, N, CSP and CHP mice on $\mathrm{ED}_{(14)}$. An ELISA kit (R\&D Systems, Minneapolis, USA) was used to measure IL-4, IL-5, IL-10 and IFN- $\gamma$ in the BAL supernatant, and the assays were performed according to the manufactureŕs instructions. The detection limit for IL- 4 was $2 \mathrm{pg} / \mathrm{mL}$, IL-5 was $7 \mathrm{pg} / \mathrm{mL}$, IL-10 was $15.6 \mathrm{pg} / \mathrm{mL}$, IL-13 was $7.8 \mathrm{pg} / \mathrm{mL}$, and for IFN- $\gamma$ it was $2 \mathrm{pg} / \mathrm{mL}$. The results were expressed in pg of interleukin produced per $\mathrm{mL}$.

2.6. Quantification of OVA-specific IgG1and IgG2a levels in peripheral blood

OVA-specific IgG1 and IgG2a antibodies were assayed in CSP and CHP mice by ELISA. Briefly, serum samples were plated on 96 wells previously coated with OVA $(2 \mu \mathrm{g} /$ well $)$. The bound antibodies were revealed with goat anti-mouse IgG1 or IgG2a for $1 \mathrm{~h}$ followed by addition of peroxidase-conjugated rabbit antigoat IgG antibodies (Southern Biotechnology, Birmingham, AL) for $1 \mathrm{~h}$. The reaction was developed by the addition of $100 \mu \mathrm{l} /$ well of o-orthophenylenediamine dihydrochloride (Sigma Chemical Company $^{\circledR}$, USA). The reaction was stopped with $4 \mathrm{M} \mathrm{H}_{2} \mathrm{SO}_{4}$ and the absorbance of the samples determined at $490 \mathrm{~nm}$. The concentrations of OVA-specific IgG1 and IgG2a antibodies were estimated by comparison with $\operatorname{IgG} 1$ and $\operatorname{IgG} 2 \mathrm{a}$ standards run in parallel on rabbit anti-mouse (Southern Biotechnology, Birmingham, AL) Ig-coated plates (Faustino et al., 2012).

\subsection{Quantification of OVA-specific IgE levels in peripheral blood}

Serum OVA-specific IgE was assayed in CSP and CHP mice by sandwich ELISA as previously described (Russo et al., 2001). Briefly, plates were coated with anti-IgE (Southern Biotechnology, Birmingham, USA) and serum was added in 1/10 dilution in PBS. Subsequently, biotin-labeled OVA was added to the wells. The bound OVA-biotin was revealed by extravidin-peroxidase (Sigma Chemical Company, USA). OVA-specific IgE levels of samples were deduced from an internal standard obtained from pooled sera of hyperimmunized mice that was arbitrarily assigned as $100 \mathrm{U} / \mathrm{mL}$ (Faustino et al., 2012).

\subsection{Analysis of L-selectin expression in BAL granulocytes}

BAL cells taken from N, CSP and CHP mice on $\mathrm{ED}_{(14)}$ were resuspended in Dulbecco-modified Eagle's medium (DMEM) containing $2 \%$ FCS. The cells were blocked with anti-CD16/anti-CD32 at a $1: 100$ dilution at $4{ }^{\circ} \mathrm{C}$ for $20 \mathrm{~min}$ to prevent nonspecific binding via the Fc receptor. After Fc blocking, the cells were stained with PE conjugated anti-mouse CD62L (L-selectin), clone MEL-14 (Biolegend, CA, USA) for $30 \mathrm{~min}$ at $4{ }^{\circ} \mathrm{C}$ according to the manufacturer's instructions. The cells were then washed twice with cold 
HBSS, resuspended in paraformaldehyde (1\%) and analyzed using a FACS Calibur cytometer (BD Bioscience, San Diego, CA). The data were analyzed using FlowJo software sa.

\subsection{In vitro tracheal responsiveness to methacholine (MCh)}

Tracheal rings were mounted for the measurement of isometric force quantification by means of two steel hooks in a $30 \mathrm{~mL}$ organ bath. Force contraction was registered using a force displacement transducer and a chart recorder (Powerlab ${ }^{\circledR}$, Labchart, AD Instruments). Briefly, tracheal rings removed from N, CSP and CHP mice on $\mathrm{ED}_{(14)}$ were suspended in an organ bath filled with $\mathrm{KH}$ at $37^{\circ} \mathrm{C}$. Tissues were continuously aerated $\left(95 \% \mathrm{O}_{2}\right.$ and $\left.5 \% \mathrm{CO}_{2}\right)$, and after the equilibrium period ( $40 \mathrm{~min}$ ), the tracheal tension was adjusted to $1 \mathrm{~g}$. Tissue viability was assessed by replacing $\mathrm{KH}$ solution with $\mathrm{KCl}$ buffer $(60 \mathrm{mM})$ in the bath and comparing the contraction force generated with those obtained previously. Next, cumulative dose-response curves to methacholine $(\mathrm{MCh})$ were constructed.

\subsection{Plasma corticosterone determination}

An ELISA kit (Life Science, Plymouth Meeting, PA, USA) was used to measure corticosterone in the plasma of CSP and CHP mice on $\mathrm{ED}_{(3)}, \mathrm{ED}_{(6)}, \mathrm{ED}_{(9)}, \mathrm{ED}_{(12)}$ and $\mathrm{ED}_{(14)}$; blood collection was performed by retro-orbital puncture. The assays were performed according to the manufactureŕs instructions. The detection limit for corticosterone was $27.0 \mathrm{pg} / \mathrm{mL}$.

\subsection{Plasma catecholamine measurement}

Plasma was removed from CSP and CHP mice on $\mathrm{ED}_{(9)}$ and $\mathrm{ED}_{(14)}$ and immediately flash frozen in liquid nitrogen to halt the degradation of catecholamines. The samples were stored at $-80^{\circ} \mathrm{C}$ prior to analysis. Plasma concentration of catecholamines was measured by HPLC. The HPLC setup for catecholamine analysis included the following: a 590 Solvent delivery module, U6K injector, 460 eletrochemical detector and M740 data module (Milipore Corp., Waters Chromatography Division, Milford, MA, USA). A Clin-Rep ${ }^{\circledR}$ column and eluent (Pharma Vertriebs GmBH \& Co KG, Munich, FRG) were used for the chromatography performed at ambient temperature. Eluent flow was $1.0 \mathrm{~mL} \mathrm{~min}{ }^{-1}$.

\subsection{Statistical analysis}

GraphPad Prism 5.0 (GraphPad Software) was used for statistical analysis. The parametric data were analyzed by Student's t test, one-way and two-way ANOVA followed by the Dunnett and Bonferroni post-tests respectively, for multiple comparisons. Since data on catecholamine were non-parametric, they were analyzed by Mann-Whitney's $U$ test. In all experiments, $p \leqslant 0.05$ was considered significant for all comparisons performed. The data are presented as the means and standard derivations.

\section{Results}

Ehrlich tumor cell injection induced behavioral changes in the sick animals. These alterations arose progressively, being characterized by the presence of lethargy, reduced activity and interest in surroundings, and decreased ability to respond to the companion mice. On $\mathrm{ED}_{(14)}$, the sick mice also presented anorexia, dyspnea, rough hair and increased abdominal volume. We performed the experiment using the naïve and the companions of health partner (CHP) and sick partner (CSP) on $\mathrm{ED}_{(14)}$.

\subsection{Cohabitation with a sick partner exacerbates allergic lung inflammation}

As depicted in Fig. 2 (Panel A), an increase $\left(F_{(2,21)}=117.0\right.$; $p<0.05)$ in the total number of leukocytes was observed in the BAL of CHP and CSP mice compared to the observed in Naïve (N) mice. Further analysis showed that CSP data were higher $(p<0.05)$ compared to that observed in CHP mice. The differential cell count, presented in Table 1 , showed an increased number of eosinophils $\left(F_{(2,21)}=80.09 ; p<0.05\right)$ and neutrophils $\left(F_{(2,21)}=127.7 ; p<0.05\right)$ in the BAL of CSP mice compared to that measured in both $\mathrm{N}$ and CHP animals. No differences $(p>0.05)$ were found in mononuclear cells in the BAL taken from $\mathrm{N}, \mathrm{CSP}$ and CHP mice.

3.2. Effects of cohabitation with a sick partner on the peripheral blood and bone marrow cells of allergic mice

As depicted in Fig. 2 (Panel B), CHP and CSP mice presented increased numbers $\left(F_{(2,21)}=21.36 ; p<0.05\right)$ of total leukocytes in the bone marrow lavage fluid in relation to $\mathrm{N}$ animals. However, a decrease $(p<0.05)$ in the total number of these cells was
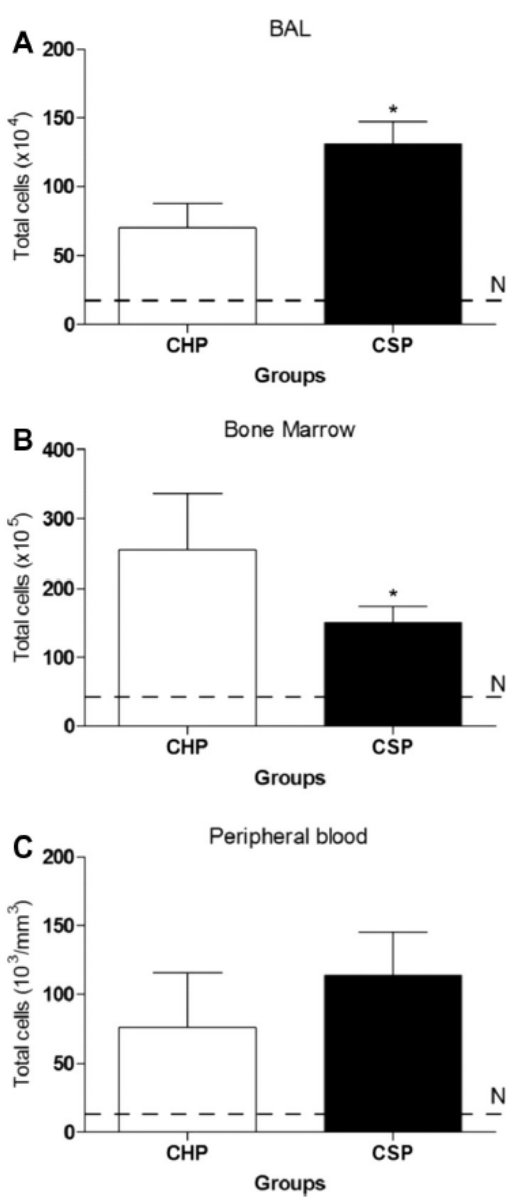

Fig. 2. Effects of cohabitation with sick cage-mate on the total BAL count (A), peripheral blood count (B), and total bone marrow count (C) of CSP and CHP mice. The dotted line depicts $(\mathrm{N})$ naïve mice. ${ }^{(*)} p<0.05$ compared to the CHP group. Data are expressed as the mean \pm SD. (One-way ANOVA followed by Dunnett post-test, $n=8$ mice/group.) 
Table 1

Differential cell count in BAL harvested from mice that lived (CSP) or not lived (CHP) with sick cage mate for 14 days.

\begin{tabular}{llcl}
\hline Groups & $\begin{array}{l}\text { Eosinophils } \\
\left(\times 10^{5}\right)\end{array}$ & \multicolumn{1}{c}{$\begin{array}{l}\text { Neutrophils } \\
\left(\times 10^{5}\right)\end{array}$} & $\begin{array}{l}\text { Mononuclear cells } \\
\left(\times 10^{6}\right)\end{array}$ \\
\hline Naïve & $0.00 \pm 0.00$ & $9.50 \pm 2.60$ & $4.80 \pm 0.60$ \\
CHP & $2.71 \pm 0.88$ & $38.33 \pm 5.71$ & $4.50 \pm 0.92$ \\
CSP & $5.10 \pm 0.83^{*}$ & $55.97 \pm 6.18^{*}$ & $5.11 \pm 0.76$ \\
\hline
\end{tabular}

CHP: Companion of health partner; CSP: companion of sick partner. Mononuclea cells $=$ macrophages + lymphocytes

$p \leqslant 0.05$ (One-way ANOVA followed by Dunnett test); $n=5-7$ animal/group.

observed in the of CSP mice compared to the N and CHP animals. As presented in Fig. 2 (Panel C), no differences $(p>0.05)$ in the total peripheral blood cell count were found among N, CSP and CHP mice.

3.3. Cohabitation with a sick partner increases IL-4 and IL-5 levels and decreases IL-10 and IFN- $\gamma$ levels in the BAL supernatant

As show in Fig. 3, cytokines (IL-4, IL-5, IL-10 and INF- $\gamma$ ) were almost not detected in the BAL supernatant of mice of the $\mathrm{N}$ group. However, the BAL obtained from CSP mice had increased levels of both IL-4 $\left(F_{(2,21)}=54.47 ; p<0.05\right.$, Panel A $)$ and IL-5 $\left(F_{(2,21)}=16.11\right.$; $p<0.05$, Panel B) and decreased levels of IL-10 $\left(F_{(2,21)}=24.33\right.$; $p<0.05$, Panel $\mathrm{C})$ and $\mu \mathrm{IFN}-\gamma\left(F_{(2,21)}=4.83 ; p<0.05\right.$, Panel D) in relation to the $\mathrm{N}$ and $\mathrm{CHP}$ animals.

3.4. Cohabitation with a sick partner increases IgG1-OVA and decreases IgG2a-OVA levels in the peripheral blood

As shown in Fig. 4, CSP mice had increased levels of IgG1-OVA $\left(F_{(2,21)}=57.11 ; p<0.05\right.$, Panel A), decreased levels of IgG2a-OVA $\left(F_{(2,21)}=102.3 ; p<0.05\right.$, Panel B) in relation to the CHP animals.
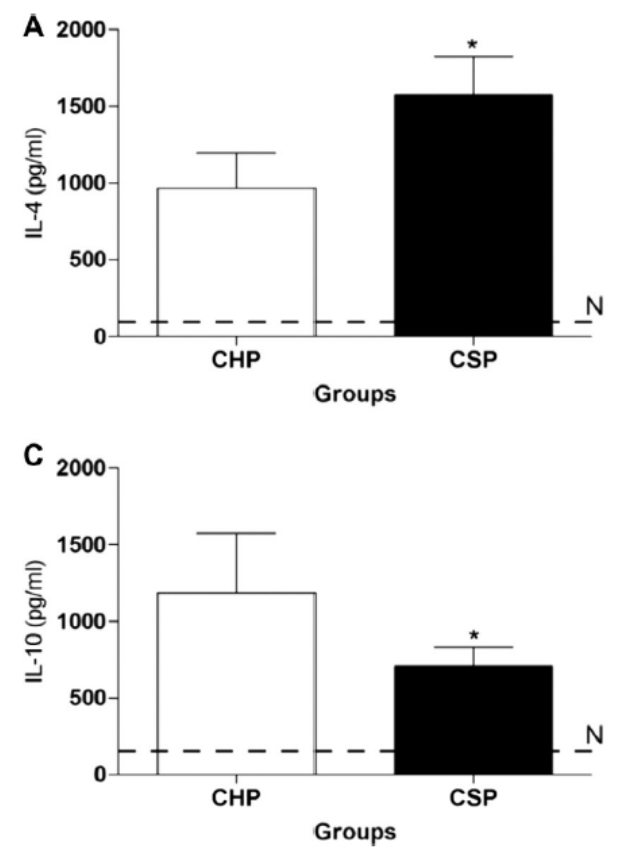

Differences were not found for IgE-OVA between CHP and CSP mice $(p>0.05$, Panel C). As expected, IgG1-OVA, IgG2a-OVA and IgE-OVA were not detected in mice of the $\mathrm{N}$ group.

3.5. Cohabitation with a sick partner affects L-selectin expression in BAL granulocytes

As shown in Fig. 5, CSP mice had increased expression of Lselectin $\left(F_{(2,21)}=22.55 ; p<0.05\right)$ in relation to $\mathrm{N}$ and CHP mice. Data from CHP and $\mathrm{N}$ groups on L-selectin were not statistically different $(p>0.05)$.

3.6. Cohabitation with a sick partner affects in vitro tracheal reactivity to methacholine

A two-way ANOVA showed significant $\left(F_{(2,6,147)}=52.81\right.$; $p<0.05)$ differences among: the three groups, the 5 different doses of MCh used and an interaction between MCh effects and the groups. As depicted in Fig. 6, tracheal responsiveness to MCh was higher in CHP and CSP mice than in Naïve $(\mathrm{N})$ animals $(p<0.05)$. Further analysis showed that the tracheal hyper-responsiveness to MCh was reduced in CSP mice compared to that measured in CHP mice $(p<0.05)$. Consistent with this, the dose-response curve for MCh was shifted to the right, and the maximal contraction achieved was decreased in the mice of the CSP group in relation to CHP group $(p<0.05)$.

\subsection{Cohabitation with a sick cage-mate does not affect plasma} corticosterone levels

Fig. 7 depicts the plasma corticosterone levels in the CHP and CSP mice. A two-way ANOVA showed significant differences among the days but no differences were found between the groups $\left(F_{(1,4,70)}=31.42 ; p<0.05\right)$. Specifically, no differences were found
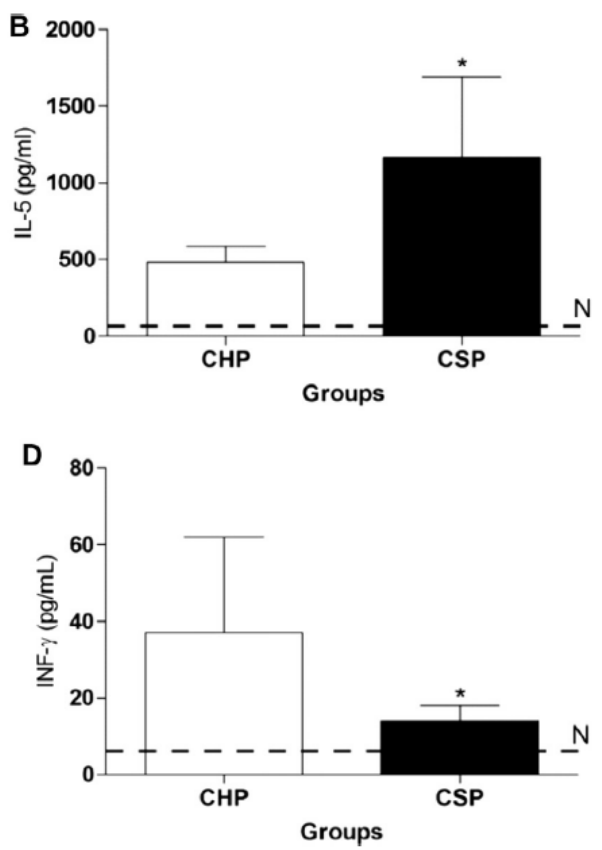

Fig. 3. Effects of cohabitation with sick cage-mate on IL-4 (A), IL-5 (B), IL-10 (C) and IFN- $\gamma$ (D) levels in the BAL supernatant of CSP and CHP mice. The dotted line depicts (N) naïve mice. ${ }^{(*)} p<0.05$ compared to the CHP group. Data are expressed as the mean \pm SD. (One-way ANOVA followed by Dunnett post-test, $n=8$ mice/group.) 

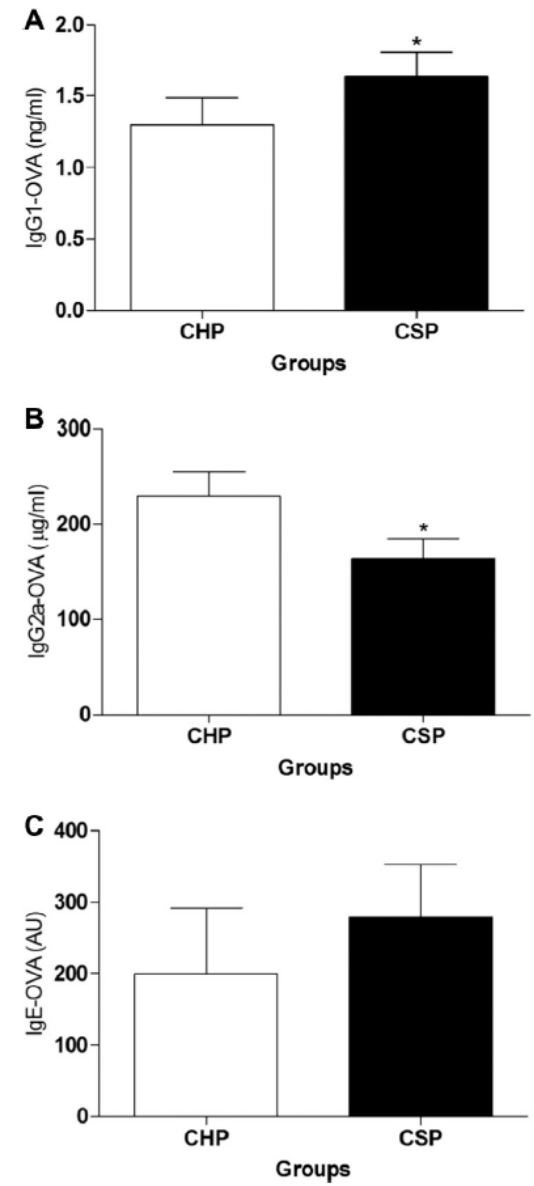

Fig. 4. Effects of cohabitation with sick cage-mate on IgG1-OVA (A) and IgG2a-OVA (B), and IgE-OVA (C) levels in the peripheral blood of CSP and CHP mice. The dotted line depicts $(\mathrm{N})$ naîve mice. ${ }^{(*)} p<0.05$ compared to the CHP group. Data are expressed as the mean $\pm S D$. (Student's $t$ test, $n=8$ mice/group.)

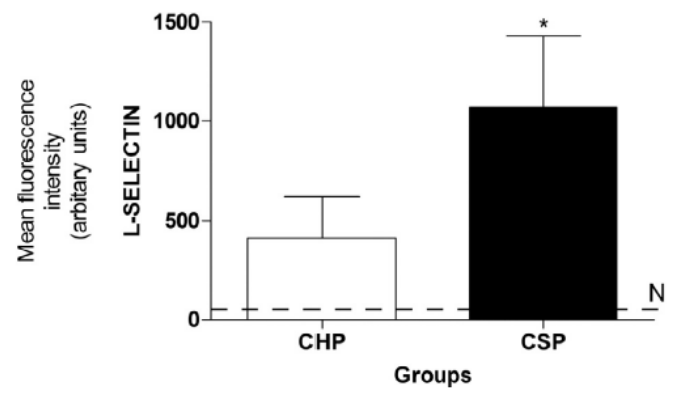

Fig. 5. Effects of cohabitation with sick cage-mate in L-selectin expression in granulocytes taken from the BAL of CSP and CHP mice. The dotted line depicts (N) naïve mice. ${ }^{(*)} p<0.05$ compared to the CHP group. Data are expressed as the mean $\pm \mathrm{SD}$. (One-way ANOVA followed by Dunnett post-test, $n=8$ mice/group.)

$(p>0.05)$ in the plasma corticosterone levels between CHP and CSP mice at any time point, i.e., on $\mathrm{ED}_{(3)}, \mathrm{ED}_{(6)}, \mathrm{ED}_{(9)}, \mathrm{ED}_{(12)}$ and $\mathrm{ED}_{(14)}$. However, most likely as a consequence of the stress induced by the

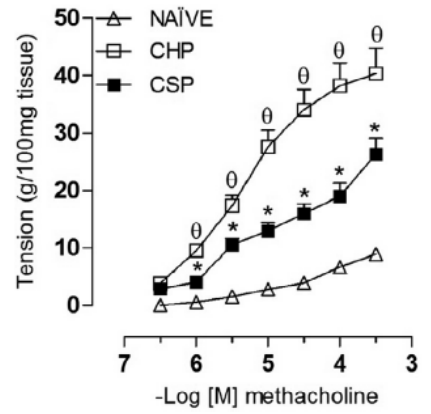

Fig. 6. Effects of cohabitation with sick cage-mate on in vitro tracheal reactivity to methacholine in CSP and CHP mice. ${ }^{(*)} p<0.05$ compared to the CHP group. $\theta$ $p<0.05$ compared to the $(\mathrm{N})$ naïve group. Data are expressed as the mean $\pm \mathrm{SD}$. (Two-way ANOVA followed by Bonferroni post-test, $n=8$ mice/group.)

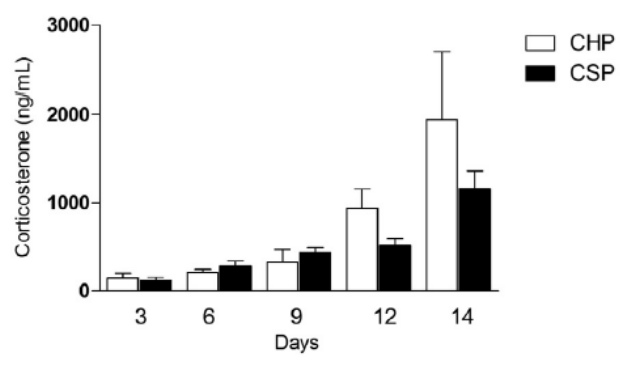

Fig. 7. Effects of cohabitation with sick cage-mate on plasma corticosterone levels of CSP and CHP mice on $\mathrm{ED}_{(3)}, \mathrm{ED}_{(6)}$, $\mathrm{ED}_{(9)}, \mathrm{ED}_{(12)}$ and $\mathrm{ED}_{(14)}$. Data are expressed as the mean $\pm S D$. ( $p>0.05$, Two-way ANOVA followed by the Bonferroni post-test, $n=8$ mice/group.)

Table 2

Plasmatic adrenaline and noradrenaline levels in mice that lived (CSP) or not lived (CHP) with sick cage mate for 9 and 14 days.

\begin{tabular}{|c|c|c|c|c|}
\hline \multirow[t]{2}{*}{ Days of cohabitation } & \multicolumn{2}{|c|}{ Adrenaline $(\mathrm{ng} / \mathrm{mL})$} & \multicolumn{2}{|c|}{ Noradrenaline (ng/mL) } \\
\hline & CHP & CSP & CHP & CSP \\
\hline 9 & $0.29 \pm 0.04$ & $0.45 \pm 0.11^{*}$ & $1.85 \pm 0.19$ & $3.98 \pm 0.69^{\circ}$ \\
\hline 14 & $0.22 \pm 0.10$ & $0.21 \pm 0.06$ & $3.34 \pm 0.79$ & $2.29 \pm 0.54^{\circ}$ \\
\hline
\end{tabular}

procedure used for blood collection, the serum corticosterone levels increased $(p<0.05)$ from $\mathrm{ED}_{(3)}$ to $\mathrm{ED}_{(14)}$ in the mice from both groups. Although no significant differences were observed between the days and groups over time, a tendency toward a smaller increase was observed in CSP mice compared to those of the CHP group.

3.8. Effects of cohabitation with sick cage-mate on plasma catecholamine levels

Table 2 shows the plasma concentrations of adrenaline and noradrenaline in the CSP and CHP mice, measured on $\mathrm{ED}_{(9)}$ and $\mathrm{ED}_{(14)}$. Differences between the CSP and CHP mice were found for both adrenaline and noradrenaline. Compared to CHP mice, the concentrations of adrenaline and noradrenaline in CSP mice were higher on $\mathrm{ED}_{(9)}(p<0.05)$. Notably, however, the plasma levels of noradrenaline were smaller $(p<0.05)$ in the CSP than in the CHP mice 
on $\mathrm{ED}_{(14)}$. No differences were found in the plasma adrenaline levels between the CSP and CHP mice on $\mathrm{ED}_{(14)}$.

\section{Discussion}

Cohabitation for 11 days with an Ehrlich tumor-bearing mouse has been reported to produce significant changes in behavior as well as in the immune and endocrine systems (Morgulis et al., 2004; Alves et al., 2006, 2007, 2012). These effects were recently reported to rely on odor clues released by the Ehrlich tumor-bearing mice. Indeed, it was shown that odors released by Ehrlich tumor-injected mice are aversive and induce psychological stress in their cage mates (Alves and Palermo-Neto, 2014). Data from the present study confirm and extend these interesting neuroimmune changes. Indeed, our data demonstrate that mice that were housed for 14 days with an Ehrlich tumor-bearing mouse presented an increased allergic lung inflammatory response.

Our study demonstrates that the CSP mice had decreased cellularity in the bone marrow and an increased number of eosinophils and neutrophils harvested from the BAL compared to CHP animals. Furthermore, a clear tendency toward an increased number of leukocytes in the peripheral blood was also found in CSP mice. The number and proportion of leukocytes present in the bone marrow, peripheral blood and inflammatory sites have been reported to characterize important features of immune system activation and immune cell distribution within the body during an immune/ inflammatory response (Ottaway and Husband, 1994; Stefanski, 2000; Engler et al., 2004; Azpiroz et al., 2008). Thus, it seems feasible to state that the stress induced by cohabitation with a sick partner was able to modulate cellular recruitment to the lungs in OVA-sensitized and challenged mice. Indeed, differences were found between CSP and CHP mice in leukocyte redistribution from the bone marrow and peripheral blood to the airway space. Previous studies have also reported that stressors are important factors in both leukocyte trafficking (Dhabhar, 2002, 2003) and the onset and exacerbation of asthma symptoms (Datti et al., 2002; Forsythe et al., 2004; Okuyama et al., 2007; Portela et al., 2007; Quarcoo et al., 2009; Hamasato et al., 2013). Thus, the present data not only agree with the previous studies but also reinforce the suggestion that cohabitation with an Ehrlich tumor-bearing mouse induces psychological stress in their cage-mates (Palermo-Neto and Alves, 2014).

Airway inflammation is one of the main characteristics of bronchial asthma, whereby eosinophils, neutrophils and lymphocytes infiltrate the lung tissue and obstruct the airway space. Stressors have been discussed as being capable of altering the Th1/Th2 cytokine balance (Tausk et al., 2008). The recruitment and migration of eosinophils into the inflamed tissue after antigen challenge is controlled by cytokines, chemokines and inflammatory mediators. Allergic immune responses are linked to Th1/Th2 imbalances with an increase in the Th2 cytokine profile (Marshall et al., 1998; Ngoc et al., 2005). In the course of allergic diseases, Th2 cytokines such as IL-4 and IL-5 increase allergen-specific IgE production and also induce the migration of leukocytes, namely eosinophils, to inflammatory loci through adhesion molecules such as L-selectin (Cotran and Mayadas-Norton, 1998). This work shows that CSP mice had increased levels of IL-4 and IL-5 and decreased levels of IL-10 and IFN $-\gamma$ in the BAL compared to animals of the CHP group. Increased expression of L-selectin was also reported in the BAL granulocytes of CSP mice. Altogether, the data obtained seem to explain the higher number of leukocytes found in the BAL of the CSP mice and strongly suggest that the psychological stress induced by cohabitation favors the release of Th2 cytokines.

IL-4 is essential for driving the differentiation of naïve Th0 cells into Th2 cells in the course of allergic inflammation (Renauld,
2001). IL-4 was also reported to facilitate isotype switching and the production of immunoglobulin E (IgE), a hallmark of allergy. IL-5 functions to differentiate, activate, and enhance the viability of eosinophils (Barnes, 2008; Finkelman et al., 2010). Activated eosinophils are known to release potent proinflammatory mediators (Holgate, 2008). Th1 cells secrete a specific profile of cytokines, including IFN- $\gamma$ and TNF- $\alpha$, that favor the cellular immune response (Nguyen and Casale, 2011). In particular, IFN- $\gamma$ has been reported to antagonize Th2 cytokine activity (Busse and Rosenwasser, 2003). In contrast, IL-10 is known to regulate the activity of both Th1 and Th2 cells (Hawrylowicz and O'Garra, 2005). Further data from our study showed that CSP mice presented increased levels of IgG1-OVA and decreased levels of IgG2a-OVA compared to CHP mice. No changes in IgE-OVA was observed between CSP and CHP mice, a fact that agree with data previously reported (Chida et al., 2007). According to Nurieva and Chung (2010), IgE and IgG1 are linked to the development of a Th2 response. Therefore, our evaluation of immunoglobulin together with that of the Th1/Th2 cytokine balance are consistent with the idea that OVA-sensitized animals that cohabitated for 14 days with an Ehrlich tumor-bearing mouse experienced a shift in the Th1/Th2 profile toward a Th2 response. The absence of differences in the levels of anti-OVA specific IgE appears to preclude the possibility that the stress of cohabitation may affect antigen sensitization.

Leukocyte migration into inflamed tissue involves complex interactions of the leukocytes with the endothelium through regulated expression of surface adhesion molecules. In the present study, we showed that CSP mice had an increased expression of L-selectin in BAL granulocytes, which might explain the increased number of eosinophils and neutrophils harvested from the BAL of CSP mice that cohabitated with Ehrlich tumor-bearing mice. Indeed, L-selectin acts as a "homing receptor" for leukocytes to enter the secondary lymphoid tissues via high endothelial venules (Scola et al., 2009).

Iwakabe et al. (1998) showed that mice subjected to a restraint stress exhibited increased serum levels of corticosterone, decreased NK cell activity and decreased production of IFN- $\gamma$ and IL-4, meaning that the stressor induced a shift in the Th1/Th2 balance, favoring Th2 responses. According to Li et al. (2013) OVAsensitized and challenged Balb/C mice submitted to a psychosocial stress of social confrontation presented behavioral signs indicative of high levels of stress and an exacerbated OVA-induced airway inflammation compared to animals that were OVA-sensitized and not stressed, showing a positive correlation between the behavioral changes observed and the aggravation of the allergic lung inflammatory response. In the present study, no differences in the serum corticosterone levels were found between CSP and CHP mice from $\mathrm{ED}_{(3)}$ through $\mathrm{ED}_{(14)}$. Corticosterone serum levels of OVA-sensitized and non-sensitized rats (Portela et al., 2007) and mice (Li et al., 2013) were shown to be the same. No differences were found in the expressions of GR protein and GR mRNA in the lung tissue of OVA-sensitized and non-sensitized Balb/C mice (Li et al., 2013). Although unexpected from a stressor, the lack of changes in corticosterone found in CSP mice of the present work agrees with previous data reported elsewhere (Morgulis et al., 2004; Alves et al., 2010). Furthermore, these data do not preclude the presence of changes in HPA activity. Indeed, decreased levels of ACTH in the presence of similar levels of corticosterone have been reported in submissive mice after a psychological stress induced by social confrontation (Lightman et al., 2002; Jahng, 2011). Thus, it is not at all impossible that the lack of significant changes observed in the serum corticosterone levels between CSP and CHP mice might also rely on HPA feedback mechanisms induced by the stress conditions imposed by the 14 days of cohabitation on the CSP animals. Data on serum corticosterone levels between CSP and CHP mice on $\mathrm{ED}_{(12)}$ and $\mathrm{ED}_{(14)}$ seem to support this notion. 
The results of our study also showed that CSP mice had reduced tracheal responsiveness to methacholine. However, as shown in Fig. 6, tracheal responsiveness to methacholine in CSP mice was higher than that measured in naïve animals. This observation is in line with data reported elsewhere because a cholinergic bronchial hyper-responsiveness has been shown in allergic lung inflammation models (Deleuze et al., 2003; Hamid et al., 2003). Notably, the observed hypo-responsiveness to methacholine in CSP mice occurred in parallel with the increase in the allergic lung inflammatory response. Other studies have demonstrated that events underlying inflammation in the lung, such as pulmonary cell influx, can be dissociated from those that govern bronchial smooth muscle tonus, i.e., that induce hypo-responsiveness (Lino dos Santos Franco et al., 2006; Ligeiro de Oliveira et al., 2012). Therefore, the data on airway responsiveness could be viewed as the result of a balance between the release of inflammatory mediators leading to bronchoconstriction (e.g. leuckotrienes, thromboxanes) and those causing bronchodilation (e.g. NO). Such mediators are not only produced by inflammatory cells recruited into the lungs but also by smooth muscle, epithelial and sensorial nervous system cells. Thus, the hypo-responsiveness observed in the CSP mice of the present work might be understood as a reflex of an elevated production of mediators that induce bronchodilation. Vaniotis et al. (2013) showed that activation of G-protein coupled to Badrenergic receptors induced NO production in cardiac tissue. Although NO release was not quantified in the present study, it seems reasonable to suggest that the tracheal hypo-responsiveness observed in the CSP mice might have been related with the production and release of NO within the airway of CSP mice.

SNS activation in response to stress increases the plasma levels of catecholamines (Elenkov et al., 2000; Kohm and Sanders, 2000; Powell et al., 2013). As shown in Table 2, a huge increase in the plasma levels of catecholamines was observed on $\mathrm{ED}_{(9)}$ in CSP mice compared to CHP animals, which is consistent with data reported previously (Alves and Palermo-Neto, 2014). These authors, using an experimental model similar to the one used in this study, reported increased levels of plasma catecholamine in CSP mice from $\mathrm{ED}_{(2)}$ till $\mathrm{ED}_{(9)}$. Relevant to state that adrenaline and noradrenaline levels of CHP mice were not statistically different from those reported in our laboratory for Naïve animals (data not shown). Catecholamine is known to change immune cell activity through G-protein coupled B-adrenergic receptors.(Kohm and Sanders, 2000). In this respect, catecholamines regulate various aspects of the humoral responses involved in asthma, including: (1) the expression of IL-4, IL-5 and IL-13 following allergen exposure (Torres et al., 2005), (2) the release of histamine by activated mast cells (Elenkov and Chrousos, 1999b) and (3) the recruitment and activation of eosinophils in the airways (Trueba and Ritz, 2013). Thus, activation of the SNS and catecholamine release due to unpleasant housing conditions might be important mediators of the stress-induced lung changes in allergic mice. Notably, however, a significant decrease in plasma noradrenaline levels was found in CSP mice on $\mathrm{ED}_{(14)}$, i.e., after 14 days of cohabitation with the sick partners. These data are consistent with previously reported data (Alves and Palermo-Neto, 2014), strongly suggesting that the SNS might also undergo physiological adaptations to the changes imposed by 14 days of cohabitation with the Ehrlich tumor-bearing mice. Notably, a tendency toward decreased levels of corticosterone in CSP mice was also observed after $\operatorname{ED}_{(12)}$. Since the levels of noradrenaline were reduced in the plasma of CSP mice on day 14 , it is reasonable to infer that this catecholamine has long-lasting effects on immune response, i.e., changes might have occurred during the OVA allergic inflammatory response induction.

In conclusion, the present data provide experimental evidence that the psychological stress induced by 14 days of cohabitation with an Ehrlich tumor-bearing partner exacerbated the allergic lung inflammatory response in CSP mice, as assessed by: (1) the increased migration and presence of eosinophils and neutrophils to the BAL, (2) the increased Th2 cytokine profile, (3) changes in IgG1-OVA and IgG2a-OVA and (4) the increased expression of Lselectin in granulocytes. However, cohabitation with a sick partner reduced tracheal responsiveness to methacholine in OVA-sensitized mice. Strong SNS participation through adrenaline and noradrenaline release seems to underlie these reported effects.

\section{Funding}

This study was supported by the FAPESP foundation (Thematic grant 2009/51886-3 and 2012/03372-3) and CNPq (578014/20084 and $300764 / 2010-3$ ) to which the authors express their sincere gratitude.

\section{Competing interests}

The authors have declared that no competing interests exist.

\section{Acknowledgment}

The authors would like to express their gratitude to Nicolle de Queiroz Hazarbassanov and Jorge Camilo Florio for assistance.

\section{References}

Ader, R., Felten, D., Cohen, N., 1990. Interactions between the brain and the immune system. Annu. Rev. Pharmacol. Toxicol. 30, 561-602.

Alves, G.J., Palermo-Neto, J., 2014. Odor cues released by ehrlich tumor-bearing mice are aversive and induce psychological stress. Neuroimmunomodulation. Alves, G.J., Ribeiro, A., Palermo-Neto, J., 2012. The neuroimmune changes induced by cohabitation with an Ehrlich tumor-bearing cage mate rely on olfactory information. Brain Behav. Immun. 26, 32-39.

Alves, G.J., Vismari, L., Florio, J.C., Palermo-Neto, J., 2006. Cohabitation with a sick cage mate: effects on noradrenaline turnover and neutrophil activity. Neurosci. Res. 56, 172-179.

Alves, G.J., Vismari, L., Lazzarini, R., Merusse, J.L., Palermo-Neto, J., 2010. Odor cues from tumor-bearing mice induces neuroimmune changes. Behav. Brain Res. $214,357-367$.

Alves, G.J., Vismari, L., Palermo-Neto, J., 2007. Cohabitation with a sick cage mate: effects on ascitic form of Ehrlich tumor growth and macrophage activity. NeurolmmunoModulation 14, 297-303.

Azpiroz, A., De Miguel, Z., Fano, E., Vegas, O., 2008. Relations between different coping strategies for social stress, tumor development and neuroendocrine and immune activity in male mice. Brain Behav, Immun. 22, 690-698.

Barnes, P.J., 2008. The cytokine network in asthma and chronic obstructive pulmonary disease. J. Clin. Investig. 118, 3546-3556.

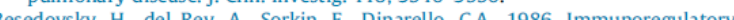
feedsky, H., del Rey, A., Sorkin, E., Dinarello, C.A., 1986. Immunoregulatory feedback

Bochner, B.S., Busse, W.W., 2005. Allergy and asthma. J. Allergy Clin. Immunol. 115, o53-959.

953-959. Ros. J A Imse, W.W., Rosenwasser,

Chida, Y., Sudo, N., Sonoda, J., Hiramoto, T., Kubo, C., 2007. Early-life psychological stress exacerbates adult mouse asthma via the hypothalamus-pituitaryadrenal axis. Am. J. Respir. Crit. Care Med. 175, 316-322.

Costa-Pinto, F.A., Palermo-Neto, J., 2010. Neuroimmune interactions in stress. NeurolmmunoModulation 17, 196-199.

Cotran, R.S., Mayadas-Norton, T., 1998. Endothelial adhesion molecules in health and disease. Pathol. Biol. (Paris) 46, 164-170.

Datti, F., Datti, M., Antunes, E., Teixeira, N.A., 2002. Influence of chronic unpredictable stress on the allergic responses in rats. Physiol. Behav. 77, 79-83. Deleuze, V., Lefort, J., Bureau, M.F., Scherman, D., Vargaftig, B.B., 2003. LPS-induced bronchial hyperreactivity: interference by mIL-10 differs according to site of delivery. Am. J. Physiol. - Lung Cell. Mol. Physiol. 286, L98-L105.

Dhabhar, F.S., 2002. Stress-induced augmentation of immune function-the role of stress hormones, leukocyte trafficking, and cytokines. Brain Behav. Immun. 16, 785-798.

Dhabhar, F.S., 2003. Stress, leukocyte trafficking, and the augmentation of skin immune function. Ann. N. Y. Acad. Sci. 992, 205-217.

Dunn, A.J., Wang, J., 1995. Cytokine effects on CNS biogenic amines. NeurolmmunoModulation 2, 319-328.

Elenkov, I.J., Chrousos, G.P., 1999a. Stress hormones, Th1/Th2 pattems, pro/antiinflammatory cytokines and susceptibility to disease. Trends Endocrinol. Metab. $10,359-368$. 10, 359-368. 
Elenkov, I.J., Chrousos, G.P., 1999b. Stress, cytokine patterns and susceptibility to disease. Baillieres Best Pract. Res. Clin. Endocrinol. Metab. 13, 583-595.

Elenkov, I.J., Webster, E.L., Torpy, D.J., Chrousos, G.P., 1999. Stress, corticotropinreleasing hormone, glucocorticoids, and the immune/inflammatory response
acute and chronic effects. Ann. NY Acad. Sci. 876, 1-11 (discussion 11-13).

Elenkov, I.J., Wilder, R.L., Chrousos, G.P., Vizi, E.S., 2000. The sympathetic nerve-an integrative interface between two supersystems: the brain and the immune system. Pharmacol. Rev. 52, 595-638.

Engler, H., Bailey, M.T., Engler, A., Sheridan, J.F., 2004. Effects of repeated social stress on leukocyte distribution

Faustino, L., Mucida, D., Keller, A.C., Demengeot, J., Bortoluci, K., Sardinha, L.R., Carl Takenaka, M., Basso, A.S., Faria, A.M., Russo, M., 2012. Regulatory T cells accumulate in the lung allergic inflammation and efficiently suppress T-cell proliferation but not Th2 cytokine production. Clin. Dev. Immunol 2012, 1-13.

Finkelman, F., Hogan, S., Hershey, G., Rothenberg. M., Wills-Karp, M., 2010. Importance of cytokines in murine allergic airway disease and human asthma. J. Immunol. 184, 1663-1674.

Forsythe, P., Ebeling, C., Gordon, J.R., Befus, A.D., Vliagoftis, H., 2004. Opposing effects of short- and long-term stress on airway inflammation. Am. J. Respir. Crit. Care Med. 169, 220-226.

Gold, P.W., 1988. Stress-responsive neuromodulators. Biol. Psychiatry 24, 371-374 Hamasato, E.K., Ligeiro de Oliveira, A.P., Lino-dos-Santos-Franco, A., Ribeiro, A. Ferraz de Paula, V., Peron, J.P., Damazo, A.S., de-Lima, W.Tavares, Palermo-Neto, J., 2013. Effects of MK- 801 and amphetamine treatments on allergic lun inflammatory response in mice. Int. Immunopharmacol. 16, 436-443.

Hamid, Q., Tulic, M.K., Liu, M.C., Moqbel, R., 2003. Inflammatory cells in asthma: mechanisms and implications for therapy. J. Allergy Clin. Immunol. 111, S5S17.

Hawrylowicz, C.M., O'Garra, A., 2005. Potential role of interleukin-10-secreting regulatory T cells in allergy and asthma. Nat. Rev. Immunol. 5, 271-283.

Holgate, S., 2008. Pathogenesis of asthma. Clin. Exp. Allergy 38, 872-897.

Iwakabe, K., Shimada, M., Ohta, A., Yahata, T., Ohmi, Y., Habu, S., Nishimura, T., 1998 The restraint stress drives a shift in Th1/Th2 balance toward Th2-dominant immunity in mice. Immunol. Lett. 62, 39-43.

Jahng, J.W., 2011. An animal model of eating disorders associated with stressfu experience in early life. Horm. Behav. 59, 213-220.

Kohm, A.P., Sanders, V.M., 2000. Norepinephrine: a messenger from the brain to the immune system. Immunol. Today $21,539-542$.

Li, B., Duan, X.H., Wu, J.F., Liu, B.J., Luo, Q.L., Jin, H.L., Du, Y.J., Zhang, H.Y., Cao, Y.X Dong, J.C., 2013. Impact of psychosocial stress on airway inflammation and its mechanism in a murine model of allergic asthma. Chin. Med. J. (Engl.) 126, 325 334

Ligeiro de Oliveira, A.P., Lino-dos-Santos-Franco, A., Acceturi, B.G., Hamasato, E.K. Machado, I.D., Gimenes Junior, J.A., Vieira, R.P., Damazo, A.S., Farsky, S.H., deLima, W.Tavares, Palermo-Neto, J., 2012, Long-term amphetamine treatment exacerbates inflammatory lung reaction while decreases airway hyperresponsiveness after allergic stimulus in rats. Int. Immunopharmacol. 14, 523-529.

Lightman, S.L., Windle, R.J., Ma, X.M., Harbuz, M.S., Shanks, N.M., Julian, M.D., Wood, S.A., Kershaw, Y.M., Ingram, C.D., 2002. Hypothalamic-pituitary-adrena function. Arch. Physiol. Biochem. 110, 90-93.

za, H.R., Domingos, H.V Oliveira-Filho, R.M. Oliani, S.M., Costa, S.K. de Lima, W.Tavares, 2006. Pulmonary neutrophil recruitment and bronchial reactivity in formaldehydeexposed rats are modulated by mast cells and differentially by neuropeptides and nitric oxide. Toxicol. Appl. Pharmacol. 214, 35-42.

Marshall Jr., G.D., Agarwal, S.K., Lloyd, C., Cohen, L., Henninger, E.M., Morris, G.J 1998. Cytokine dysregulation associated with exam stress in healthy medica students. Brain Behav. Immun. 12, 297-307.

Morgulis, M.S., Stankevicius, D., Sa-Rocha, L.C., Palermo-Neto, J., 2004. Cohabitatio with a sick cage mate: consequences on behavior and on ehrlich tumor growth. NeurolmmunoModulation 11, 49-57.

Nagata, A., Yamada, Y., Nakamura, A., Asano, T., Yamada, T., Isaka, M., Itoh, M., 1999. Alteration of endogenous corticosteroids and catecholamines in allergeninduced eosinophilic inflammation in Brown Norway rats. Allergol. Int. 48, 209-215.

Ngoc, P., Ngoc, L., Gold, D., Tzianabos, A., Weiss, S., Celedón, J., 2005. Cytokines, allergy, and asthma. Curr. Opin. Allergy Clin. Immunol. 5, 161-166.

truyen, T.-H.T., Casale, T.B., 2011. Immune modulation for treatment of allergic disease. Immunol. Rev. 242, 258-271.

urieva, R.l., Chung, Y., 2010. Understanding the development and function of follicular helper cells. Cell. Mol. Immunol. 7, 190-197.
Okuyama, K., Ohwada, K., Sakurada, S., Sato, N., Sora, I., Tamura, G., Takayanagi, M., Ohno, 1., 2007. The distinctive effects of acute and chronic psychological stress on airway inflammation in a murine model of allergic asthma. Allergol. Int. 56, 29-35.

Ottaway, C.A., Husband, A.J., 1994. The influence of neuroendocrine pathways on lymphocyte migration. Immunol. Today $15,511-517$.

Palermo-Neto, J., Alves, G.J., 2014. Neuroimmune interactions and psychologycal stress induced by cohabitation with a sick partner: a review. Curr. Pharm. Des.

Palermo-Neto, J., de Oliveira Massoco, C., Robespierre de Souza, W., 2003. Effects of physical and psychological stressors on behavior, macrophage activity, and Ehrlich tumor growth. Brain Behav. Immun. 17, 43-54.

Palermo-Neto, J., Fonseca, E.S., Quinteiro-Filho, W.M., Correia, C.S., Sakai, M., 2008. Effects of individual housing on behavior and resistance to Ehrlich tumor growth in mice. Physiol. Behav. 95, 435-440.

Persoons, J.H., Berkenbosch, F., Schornagel, K., Thepen, T., Kraal, G., 1995. Increased specific lgE production in lungs after the induction of acute stress in rats. J. Allergy Clin. Immunol. 95, 765-770.

Portela, C., Leick-Maldonado, E., Kasahara, D., Prado, C., Calvo-Tibério, I., Martins, M., Palermo-Neto, J., 2007. Effects of stress and neuropeptides on airway responses in ovalbumin-sensitized rats. NeurolmmunoModulation 14, 105-111.

Portela, P., Massoco Cde, O., de Lima, W.T., Palermo-Neto, J., 2001. Stress-induced increment on total bronchoalveolar cell count in OVA-sensitized rats. Physiol. Behav. 72, 415-420.

Portela, P., Tiberio Ide, F., Leick-Maldonado, E.A., Martins, M.A., Palermo-Neto, J., 2002. Effects of diazepam and stress on lung inflammatory response in OVAsensitized rats. Am. J. Physiol. Lung Cell. Mol. Physiol. 282, L1289-L1295.

Powell, N.D., Tarr, A.J., Sheridan, J.F., 2013. Psychosocial stress and inflammation in cancer. Brain Behav. Immun. 30 (Suppl.), S41-S47.

Quarcoo, D., Pavlovic, S., Joachim, R., 2009. Stress and airway reactivity in a murine model of allergic airway inflammation. NeurolmmunoModulation 16, 318-324. Renauld, J.-C., 2001. New insights into the role of cytokines in asthma. J. Clin. Pathol. $54,577-589$.

Rietveld, S., Everaerd, W., Creer, T.L., 2000. Stress-induced asthma: a review of research and potential mechanisms. Clin. Exp. Allergy 30, 1058-1066.

Russo, M., Nahori, M.A., Lefort, J., Gomes, E., Castro-Keller, A., Rodrigues, D., 2001. of asthma-like responses in different mouse strains by oral tolerance. Am. J. Respir. Cell. Mol. Biol. 24, 518-526.

Scola, A.M., Loxham, M., Charlton, S.J., Peachell, P.T., 2009. The long-acting betaadrenoceptor agonist, indacaterol, inhibits lgE-dependent responses of human lung mast cells. Br. J. Pharmacol. 158, 267-276.

Segura, J.A., Barbero, L.G., Marquez, J., 1997. Early tumor effect on splenic Th lymphocytes in mice. FEBS Lett. 414, 1-6.

Stankevicius, D., Ferraz-de-Paula, V., Ribeiro, A., Pinheiro, M.L., Ligeiro de Oliveira, A.P., Damazo, A.S., Lapachinske, S.F., Moreau, R.L, de Lima, W.Tavares, PalermoNeto, J., 2012. 3,4-Methylenedioxymethamphetamine (ecstasy) decreases inflammation and airway reactivity in a murine model of asthma. NeurolmmunoModulation 19, 209-219.

Stefanski, V., 2000. Social stress in laboratory rats: hormonal responses and immune cell distribution. Psychoneuroendocrinology 25, 389-406.

Tausk, F., Elenkov, L., Moynihan, J., 2008. Psychoneuroimmunology. Dermatol. Ther. $21,22-31$

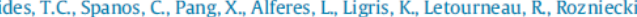
J.J., Webster, E., Chrousos, G.P., 1995. Stress-induced intracranial mast cell degranulation: a corticotropin-releasing hormone-mediated effect. Endocrinology 136, 5745-5750.

Tomiyoshi, M.Y., Sakai, M., Baleeiro, R.B., Stankevicius, D., Massoco, C.O., PalermoNeto, J., Barbuto, J.A., 2009. Cohabitation with a B16F10 melanoma-bearer cage mate influences behavior and dendritic cell phenotype in mice. Brain Behav. Immun. 23, 558-567.

Torres, K.C., Antonelli, L.R., Souza, A.L., Teixeira, M.M., Dutra, W.O., Gollob, K.J., 2005. Norepinephrine, dopamine and dexamethasone modulate discrete leukocyte subpopulations and cytokine profiles from human PBMC. J. Neuroimmunol. $166,144-157$

Trueba, A.F., Ritz, T., 2013. Stress, asthma, and respiratory infections: pathways involving airway immunology and microbial endocrinology. Brain Behav. Immun. 29, 11-27.

Vamos, M., Kolbe, J., 1999. Psychological factors in severe chronic asthma. Aust. N. Z J. Psychiatry 33, 538-544.

aniotis, G., Glazkova, I., Merlen, C., Smith, C., Villeneuve, L.R., Chatenet, D., Therien, M., Fournier, A., Tadevosyan, A., Trieu, P., Nattel, S., Hebert, T.E., Allen, B.G, 2013. Regulation of cardiac nitric oxide signaling by nuclear beta-adrenergic and endothelin receptors. J. Mol. Cell. Cardiol. 62, 58-68.

Zosky, G., Sly, P., 2007. Animal models of asthma. Clin. Exp. Allergy 37, 973-988. 


\section{ANEXO B}

Figura 1- Efeitos da coabitação aguda com um conspecífico injetado com LPS ( $500 \mu \mathrm{g} / \mathrm{Kg})$ sobre o comportamento social avaliado na caixa de investigação social com um novo parceiro.
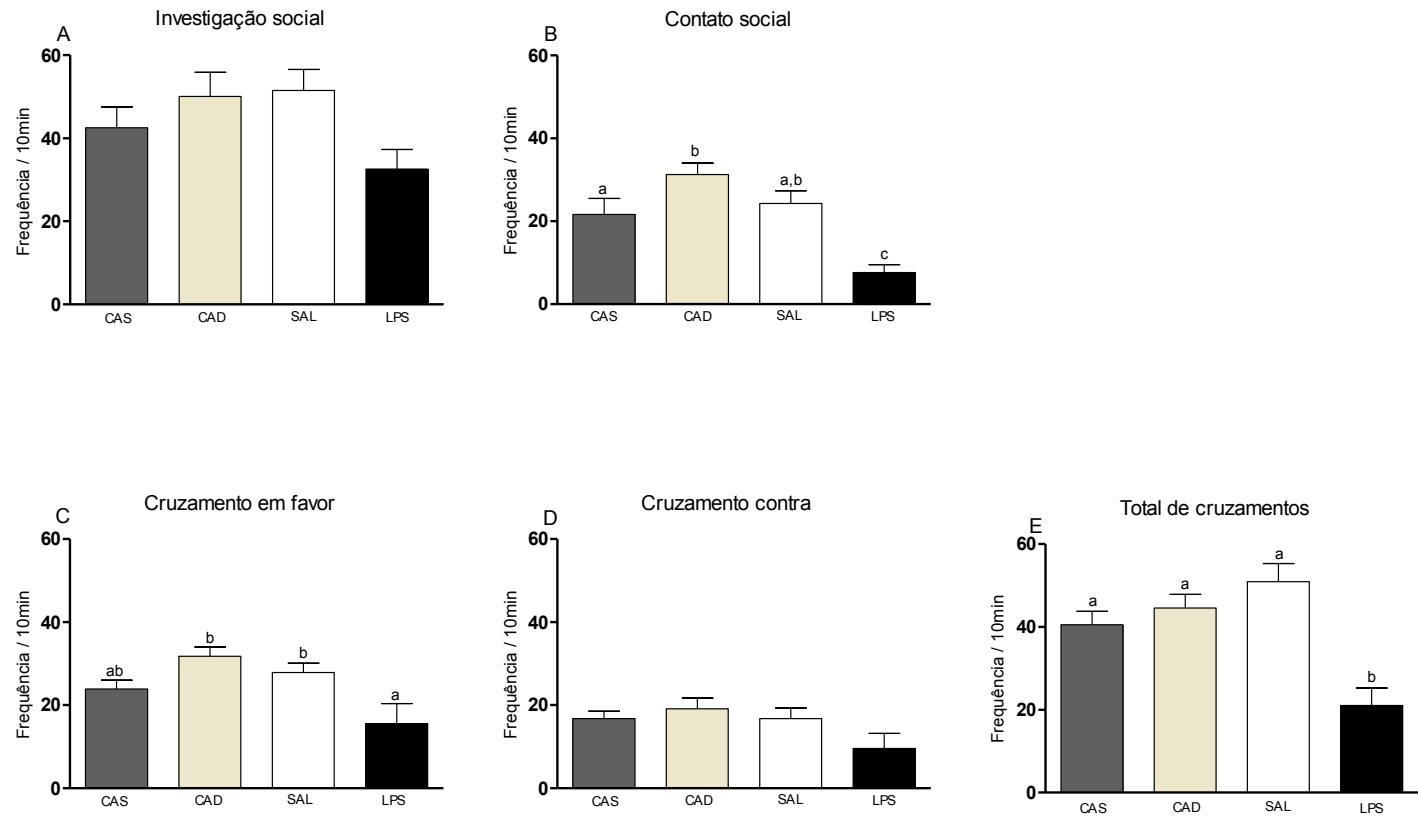

Legenda: CAS: companheiros dos animais saudáveis; CAD: companheiro dos animais doentes; SAL: animais injetados com solução salina; LPS: animais injetados com LPS $(500 \mu \mathrm{g} / \mathrm{Kg})$. Diferentes letras significam diferenças entre os grupos. 
Figura 2 - Efeitos da coabitação aguda com um conspecífico injetado com LPS $(500 \mu \mathrm{g} / \mathrm{Kg})$ sobre os níveis de corticosterona plasmáticos avaliados imediatamente (B), 15, 30, 60 minutos após o desafio por contenção e 120 minutos.

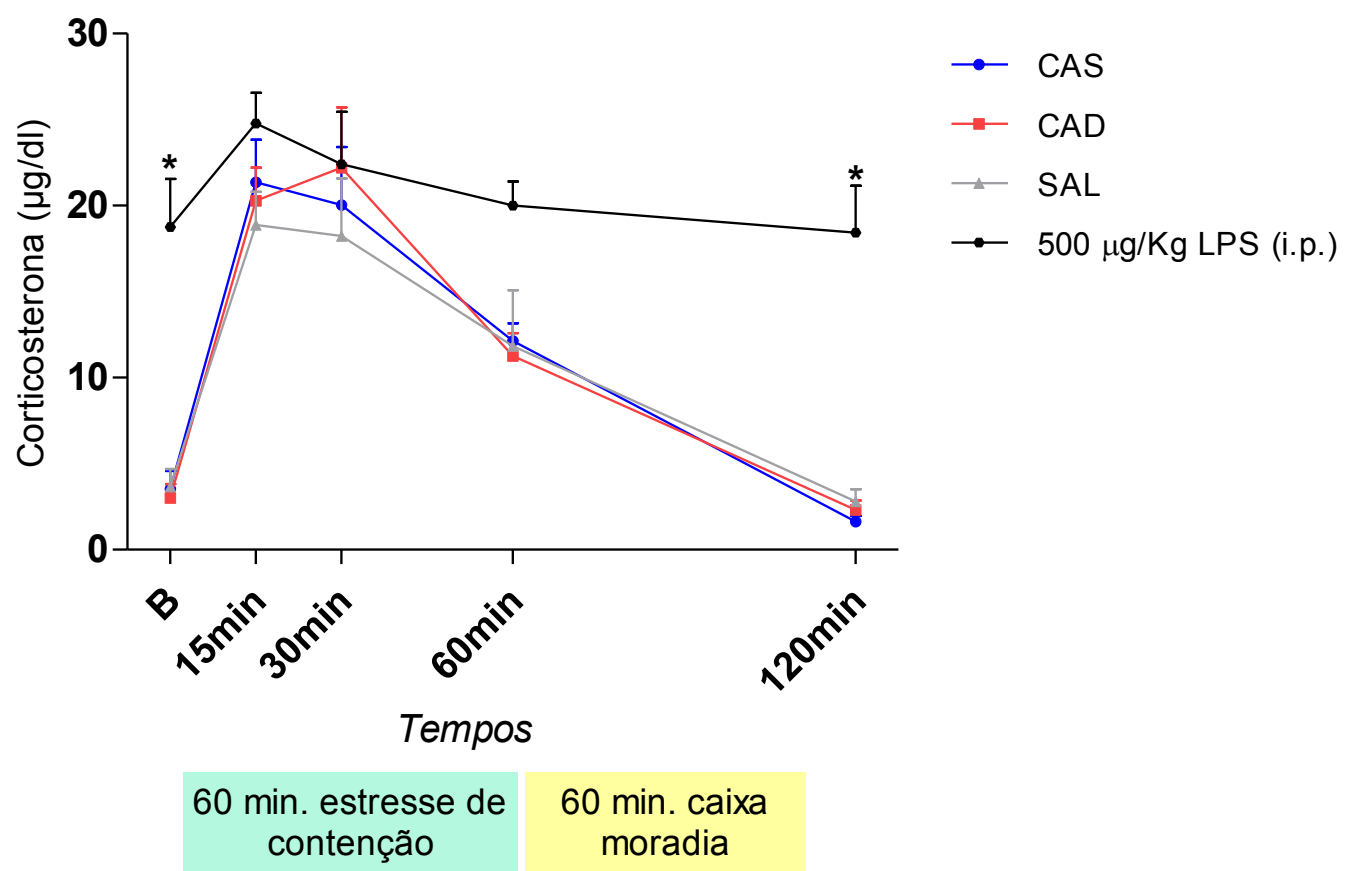

Legenda: CAS: companheiros dos animais saudáveis; CAD: companheiro dos animais doentes; SAL: animais injetados com solução salina; LPS: animais injetados com LPS $(500 \mu \mathrm{g} / \mathrm{Kg})$. B: nível basal. *Diferença significativa quando comparado ao grupo SAL. 
Figura 3 - Efeitos da coabitação aguda com um conspecífico injetado com LPS ( $500 \mu \mathrm{g} / \mathrm{Kg})$ sobre os níveis de citocinas IL-1 $\beta$ (A), IL-6 (B), TNF- $\alpha$ (C) e Iк B $\alpha$ (D) no bulbo olfatório, CeA e PVN avaliados após o desafio com a injeção de salina ou LPS $(25 \mu \mathrm{g} / \mathrm{Kg})$.

\section{Bulbo olfatório}
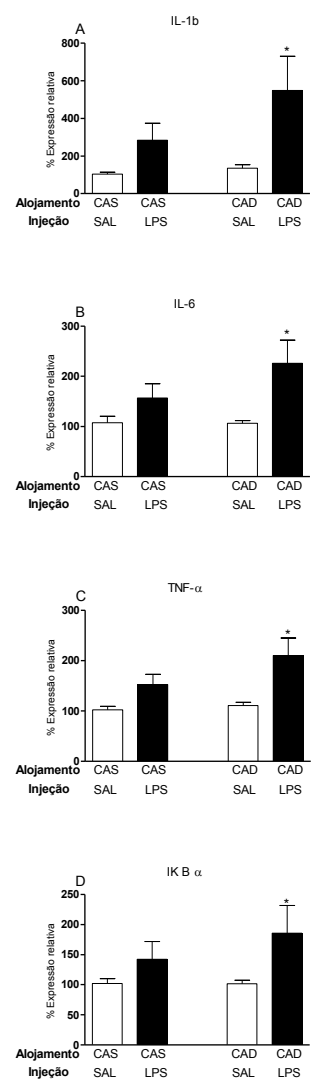

CeA
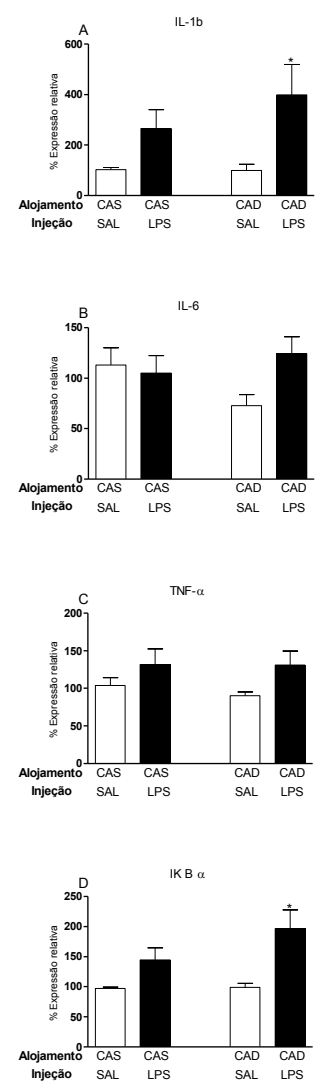

PVN
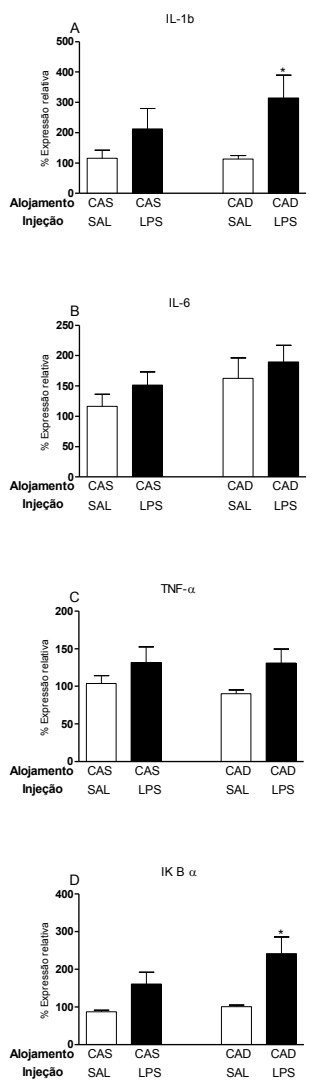

Legenda: CAS: companheiros dos animais saudáveis; CAD: companheiro dos animais doentes; SAL: animais injetados com solução salina; LPS: animais injetados com LPS $(25 \mu \mathrm{g} / \mathrm{Kg})$. CeA: núcleo central da amigdala. PVN: núcleo paraventricular do hipotálamo *Diferença significativa quando comparado ao grupo CAS injetado com LPS. 